This is an Accepted Manuscript of an article published by Taylor \& Francis in Reviews in Fisheries Science \& Aquaculture on 08/12/20, available online:

http://www.tandfonline.com/10.1080/23308249.2020.1822280 


\section{Review and Meta-Analysis of the Environmental Biology and Potential Invasiveness of a Poorly-Studied Cyprinid, the Ide Leuciscus idus}

Mehis Rohtla ${ }^{\mathrm{a}, \mathrm{b}}$, Lorenzo Vilizzi ${ }^{\mathrm{C}}$ (D), Vladimír Kováčc ${ }^{\mathrm{d}}$, David Almeida ${ }^{\mathrm{e}}$, Bernice Brewster ${ }^{\mathrm{f}}, \mathrm{J}$

Robert Britton ${ }^{\mathrm{g}}$, Łukasz Głowacki ${ }^{\mathrm{c}}$, Michael J. Godard ${ }^{\mathrm{h}, \mathrm{i}}$, Ruth Kirk ${ }^{\mathrm{f}}$, Sarah Nienhuis ${ }^{\mathrm{j}}$, Karin H. Olsson ${ }^{\mathrm{h}, \mathrm{k}}$, Jan Simonsen, Michał E. Skóra ${ }^{\mathrm{m}}$, Saulius Stakènas ${ }^{\mathrm{n}}$, Ali Serhan Tarkan ${ }^{\mathrm{c}, \mathrm{o}}$, Nildeniz Top ${ }^{\circ}$, Hugo Verreycken ${ }^{\mathrm{p}}$, Grzegorz Zięba ${ }^{\mathrm{c}}$, and Gordon H. Copp $\mathrm{p}^{\mathrm{c}, \mathrm{h}, \mathrm{q}}$

${ }^{a}$ Estonian Marine Institute, University of Tartu, Tartu, Estonia

${ }^{\mathrm{b}}$ Institute of Marine Research, Austevoll Research Station, Storebø, Norway

cDepartment of Ecology \& Vertebrate Zoology, University of Lodz, Lodz, Poland

${ }^{\mathrm{d} C}$ Comenius University, Faculty of Natural Sciences, Department of Ecology, Bratislava, Slovakia

eDepartment of Basic Medical Sciences, USP-CEU University, Madrid, Spain

fMolecular Parasitology Laboratory, School of Life Sciences, Pharmacy and Chemistry, Kingston University, Kingston upon Thames, Surrey, UK

${ }^{\mathrm{g} C e n t r e ~ f o r ~ E c o l o g y, ~ E n v i r o n m e n t ~ a n d ~ S u s t a i n a b i l i t y, ~ B o u r n e m o u t h ~ U n i v e r s i t y, ~ F e r n ~ B a r r o w, ~}$ Poole, Dorset, UK

${ }^{\mathrm{h}}$ Centre for Environment, Fisheries \& Aquaculture Science, Pakefield Road, Lowestoft, Suffolk, UK

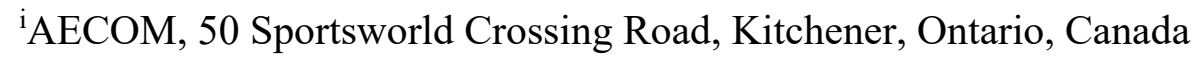

jOntario Ministry of Natural Resources and Forestry, Peterborough, Ontario, Canada

${ }^{\mathrm{k}}$ Department of Zoology, Tel Aviv University and Inter-University Institute for Marine Sciences in Eilat, Israel

${ }^{1}$ Institute of Marine Research, Flødevigen Research Station, Norway

${ }^{m}$ University of Gdansk, Faculty of Oceanography and Geography, Institute of Oceanography, Professor Krzysztof Skóra Hel Marine Station, Morska, Hel, Poland

${ }^{\mathrm{n} D e p a r t m e n t ~ o f ~ F i s h ~ E c o l o g y, ~ N a t u r e ~ R e s e a r c h ~ C e n t r e, ~ V i l n i u s, ~ L i t h u a n i a ~}$ 
${ }^{\circ}$ Muğla Sıtkı Koçman University, Faculty of Fisheries, Department of Basic Sciences, Muğla, Turkey

${ }^{\mathrm{p}}$ Research Institute for Nature \& Forest, Brussels, Belgium

${ }^{\mathrm{q}}$ School of the Environment, Trent University, Peterborough, Ontario, Canada

CONTACT Lorenzo Vilizzi lorenzo.vilizzi@gmail.com Department of Ecology \& Vertebrate 33 Zoology, University of Lodz, Lodz, Poland 


\section{Abstract}

The ide Leuciscus idus is a large-bodied cyprinid native to freshwaters around the Baltic, Black, Caspian and North seas. Historically an important commercial species, the ide is exploited in recreational fisheries and as an ornamental fish, and is subject to translocation and stocking events. The ide is less well-studied than many European cyprinids and relatively little is known of the risks it poses to native species and ecosystems where introduced. The present review and meta-analysis examine available data on the ide environmental biology to provide an assessment of its potential invasiveness. A long-lived, omnivorous species, the ide is a habitat generalist that inhabits lowland rivers and nutrient rich lakes, but also some brackish waters where it is facultatively anadromous. The ide displays variable age and length at maturity and asymptotic growth in body length, can be highly productive and migratory, and can withstand variable environmental conditions. Despite several attributes that should facilitate acclimation of the ide to novel environments, the species has established relatively few self-sustaining populations outside its native range, and is therefore not considered to be invasive. As introductions are likely to continue, this propagule pressure could lead to the development of invasive non-native populations in some locations.

\section{Keywords}

Morphology; distribution; diet; habitat use; growth; reproduction; parasites; non-native species; environmental impact 


\section{Introduction}

Translocations and introductions of freshwater fish species have a long history in Europe (Copp et al. 2005). Some of these species, such as the ide Leuciscus idus, have received relatively little scientific study in both their native and introduced ranges (e.g. Brabrand 1985; Kulíšková et al. 2009; Rohtla et al. 2015a). This is despite the ide domestication and increased use in restoration aquaculture (e.g. Krejszeff et al. 2009; Kupren et al. 2010). Historically a species of economic importance (e.g. Järvalt et al. 2003; Ståhlberg and Svanberg 2011), commercial fisheries for ide have existed in the rivers Ob and Irtysh of East Siberia (Berg 1949; Zhuravlev and Solovov 1984), as well as in some parts of the Baltic Sea, where angling for anadromous populations is still common (Järvalt et al. 2003; Skovrind et al. 2016). The current economic importance of ide in North America (e.g. Mandrak et al. 2014; Howeth et al. 2016) and in some European countries relates to the species' use as a garden pond fish (Vooren 1972; Lever 1977; Copp et al. 2005; Hanel et al. 2011; Harzevili et al. 2012) and as a sport fish for recreational angling (Järvalt et al. 2003), including the ornamental varieties (Hickley and Chare 2004) known as blue orfe and golden orfe (Smith 1995). The name 'ide' is from Swedish $i d$, originally referring to its bright colour. According to 'Svensk ordbok' (http://svenska.se) it is old Swedish/old Norse and can be dated to 1459-1460 (medieval accountancy documents from Stockholm). Its likely original meaning was glödande (glowing) or strålande (radiant).

Although the ide has been introduced to several parts of the world (e.g. North America, New Zealand, UK, and non-native parts of continental Europe), making it a potentially invasive species, there remains a paucity of information regarding the ide potential threat to native species and ecosystems. In fact, with such poorly-studied species, non-native species risk assessments tend to be characterised by elevated uncertainty (Hill 2009; Humair et al. 2014). To mitigate this, extensive reviews of available past and current literature, from both peerreviewed and 'grey' sources, have proved useful to inform the risk analysis process of less 
well-studied species (e.g. Copp et al. 2009a, 2016). Following this approach, the aim of the present study was to carry out a review and meta-analysis of available data and information on the environmental biology of ide, encompassing the species' morphology, distribution, habitat use, ontogeny and growth, reproduction, diet, predators, and parasites and pathogens under natural conditions. The present study thus excludes all literature that covers the use of ide in aquaculture, except for those documents that have a direct bearing on its environmental biology. The present review concludes with a general discussion on the species' potential invasiveness and consequential threat to native species and ecosystems.

\section{Review}

\subsection{Morphology}

The genus Leuciscus is one of several genera of the family Cyprinidae in Eurasia. The ide has a streamlined body, with a wide head, blunt snout, and terminal mouth. The dimensions and position of the fins indicate that ide is mainly a still-water species, though this preference for lentic waters appears to hold for juvenile individuals, as sub-adults show a preference for water velocities up to $0.8 \mathrm{~m} \mathrm{~s}^{-1}$, with no such preference demonstrated by adults (Scholten et al. 2003). Dorsal and ventral fins are almost opposite to each other, with the anal fin having a straight or slightly concave hind edge. The dorsal fin usually has three unbranched and eight branched rays, though specimens from the rivers $\mathrm{Ob}$, Kama and Yenisei (Siberia) and from Lake Võrtsjärv (Estonia) have been reported to have 7-9 branched rays (Berg 1949; Järvalt et al. 2003). The pectoral fins have one unbranched and 16-17 branched rays, whereas the respective numbers in the ventral and anal fins are two and eight, and three and 8-12, respectively (Järvalt et al. 2003). In male ide, the first unbranched ray of the pectoral fin is much thicker than in females (Järvalt et al. 2003) and all fins are olive-grey or reddish in colour (Tadajewska 2000; Järvalt et al. 2003). Pharyngeal teeth are in two rows (3.5-5.3, rarely 2.55.2) and hooked at the top (Järvalt et al. 2003). Eyes are slightly yellow, the back is green to 
blackish grey, sides are silvery, and the belly is white. During the spawning period, nuptial tubercles are present on the head and body of both sexes, but to a lesser extent on females (Järvalt et al. 2003). The number of scales of the lateral line varies moderately between populations, ranging from 51 to 65 (Veld 1969; Järvalt et al. 2003). The number of gill rakers and vertebrae is usually 10-15 and 45-48, respectively (Järvalt et al. 2003).

There has been little study of the geographical variability in ide morphology. Xantoric varieties (L. idus aberr. orfus) have been reared in Europe since the $18^{\text {th }}$ century, perhaps resulting from intentional selection of mutated individuals (Berg 1949). Currently, the ornamental varieties of ide, golden and blue orfe are reared in Belgium, the Netherlands, New Zealand, Germany, Italy, and the USA (Koopmans and van Emmerik 2006), with imports to the UK in 2000-2004 coming from the latter three countries (Copp et al. 2007). Specimens of golden and blue orfe tend not to differ from the wild form in terms of life-history traits, but may exhibit some variation in the proportions of their body shape (Witkowski et al. 1997).

\subsection{Distribution}

The native distribution of ide encompasses the river basins that drain into the Baltic, Black, Caspian, White, Barents, Kara, and Laptev seas, extending from the River Rhine basin in the west to Sweden and Finland in the north, to the River Lena basin in the east, and to the Alps and the northern parts of the Black and Caspian seas basins in the south (Fig. 1). The ide is also a common species in the brackish Baltic, Caspian, and Azov seas (Järvalt et al. 2003; Bogutskaya and Naseka 2006). Genetic research on ide is limited to few studies of population structure and demographic history, which have demonstrated higher levels of differentiation amongst freshwater relative to anadromous populations (Wolter et al. 2003; Barinova et al. 2004; Zhigileva et al. 2010; Skovrind et al. 2016). 
The ide has been introduced into some European countries outside its native Eurasian range (Fig. 1), however its native status in some countries remains contentious. For example, in France, Spain, the Netherlands, and Britain the ide is listed as having been introduced with successfully established self-sustaining populations (Holčík 1991; Elvira 2001). In the case of France (Keith et al. 2011), the ide may be native to eastern waters that drain into the Rhine basin, while the ornamental variety 'ide rouge' has been introduced elsewhere (Spillmann 1961). At least two Dutch sources refer to the ide as being native to the Netherlands (i.e. Koopmans and van Emmerik 2006; Schiphouwer et al. 2014), which includes the River Rhine (Leuven et al. 2011). Undated specimens of ide in the collection of the Muséum National d'Histoire Naturelle de Paris are attributed to the Rhine and two of its tributaries in France, the rivers Moselle and Ill (Pascal et al. 2003). A similar incertitude exists for the Iberian Peninsula, where the ide was previously listed amongst fish species introduced to France but not found in Iberia (Clavero and García-Berthou 2006). Here, the ide was however subsequently reported to have been introduced in the 2000s (Leunda 2010) and is a well-known vector for non-native fish introductions to open waters (Chan et al. 2019). Although previously reported as present in Italy (Copp et al. 2005), a recent re-evaluation found this not to be the case (P. Bianco, personal communication). Greater certainty exists for the UK, where an initial introduction in 1874 to lakes at Woburn Abbey (Bedfordshire, England), followed by reports in 1879 of the species in the wild, is well documented (Wheeler and Maitland 1973; Lever 1977). During this era of 'acclimation societies' (mid-1 $19^{\text {th }}$ to early $20^{\text {th }}$ centuries), introductions of fish for ornamental purposes, such as pumpkinseed Lepomis gibbosus, golden orfe and bitterling Rhodeus amarus, occurred both in England (Copp et al. 2007) and elsewhere (Copp et al. 2005), including ponds of aristocratic estates of the Russian Empire beginning in 1902 (Virbickas 2000). Subsequent introductions of the ide, especially golden and blue orfe, for angling have occurred into water bodies throughout most of England and Wales (Wheeler and 
Maitland 1973; Hickley and Chare 2004), where the ide is now present in ponds and water courses (Copp et al. 2006, 2007).

Introductions of the ide to non-native locations have also occurred within its native range (cf. translocations). For example, in Slovakia golden orfe was introduced to a natural alpine lake (Štrbské Pleso), which is located at $1346 \mathrm{~m}$ a.s.l. in the High Tatra mountains (Balon and Žitňan 1964). This introduction occurred in the 1930s or early 1940s, and the population still thrives in this lake despite unfavourable conditions of cold water and ice cover lasting for almost six months a year. Introductions outside of Europe include North America and New Zealand. Ide was initially introduced to the USA in 1877 and has since been recorded in at least 22 states, including golden orfe in garden ponds and aquaculture facilities of California (Dill and Cordone 1997). Despite a long history of introductions in the USA, a paucity of confirmed, recent records of established populations in that country suggests that most of these introductions have been unsuccessful. With the record being poor and contradictory (Nico et al. 2020), there is high uncertainty about the current status and distribution of ide in the USA. In Canada, there are currently no reported wild populations. Furthermore, the ide is not currently known to occur in the Great Lakes region, though occurrence records for the species do exist from all of the Great Lakes states except for Michigan and Wisconsin (Nico et al. 2020). Further, in the mid-1980s golden orfe was introduced to several ponds north of Auckland in New Zealand, and earlier reports indicated that the species may have established self-sustaining populations in these small ponds or lakes (Chadderton 2003), though its range was believed to be highly localised (McDowall 2000). Despite extensive surveys (B. David, personal communication), there have been no recent confirmed reports on the continued presence of ide in New Zealand (Collier and Grainger 2015). 


\subsection{Habitat use}

The ide is a benthopelagic, rheophilic, and potamodromous species that can occupy a wide range of habitats from various freshwater body types to brackish waters. Its habitat is described as a general preference for deep, clean, and cool water of rivers and lakes (Wheeler 1978; Witeska et al. 2014), including large, flow-through, nutrient-rich lakes (Cala 1970; Virbickas 2000; Järvalt et al. 2003; Winter and Fredrich 2003; Kulíšková et al. 2009). In the rivers Eg and Uur (Mongolia), ide habitat was described as consisting of slow water velocities in the water column over gravel substratum (Mercado-Silva et al. 2008). The ide is also known to inhabit and feed in brackish estuaries as well as in the Baltic and Caspian seas, where it is commonly found at salinities $<8$ (Müller and Berg 1982; Järvalt et al. 2003; Bogutskaya and Naseka 2006). Brackish water ide can usually withstand salinities up to 15 (van Beek 1999), with extreme examples of populations from the Öresund Strait (Sweden) and Zuiderzee (Netherlands), where salinities can temporarily reach even 20 (Veld 1969; Cala 1970). Finally, sudden influxes of saline waters into these habitats are often responsible for mass kills (Carl 2012).

The ide uses a variety of habitats during different seasons and life history stages, tending to inhabit rivers and flood plains in the early spring to spawn, and shallower littoral or shoreline habitats as larvae and juveniles (e.g. Grift et al. 2003). During the winter, the ide typically retreats to deep holes or refuges in lakes or in the lower stretches of rivers (McDowall 2000). When feeding, the ide seeks out "deep quiet embayments and oxbows, especially where the bottom is overgrown with soft submerged macrophytes" (Dulmaa 1999). In the rehabilitated sections of the River Rhine flood plain, juvenile ide were restricted to shallow areas $(<1 \mathrm{~m}$ deep) of various water velocities $\left(0-0.40 \mathrm{~m} \mathrm{~s}^{-1}\right)$ with little $(1-5 \%)$ inundated terrestrial vegetation cover (Grift et al. 2003). Disappearance of these habitats, caused by river regulation, 
canalisation, and embankments, is thought to be the limiting factor for growth and survival during the early ontogeny of rheophilic cyprinids (Grift et al. 2003).

Given the broad native range of the ide (cf. Section 2.2: Distribution), the species tolerates a wide range of temperatures, though the preferred temperature range is $4-20{ }^{\circ} \mathrm{C}$, with minimum and maximum tolerated temperature of near $0{ }^{\circ} \mathrm{C}$ and $35^{\circ} \mathrm{C}$, respectively (Leuven et al. 2011). Laboratory studies of upper lethal temperatures for ide under controlled conditions revealed an ability of embryos, larvae, and juveniles to acclimatise to and tolerate increasing water temperatures (Florez 1972a; Kupren et al. 2010). A general lethal/stress range of 24$27^{\circ} \mathrm{C}$ has been reported for this species (Lehtonen 1996).

Despite having broad temperature and salinity tolerance, the ide is intolerant of low dissolved oxygen concentrations, such as in heavily polluted or eutrophic and turbid waters, with significant mortality of larvae and juveniles at oxygen concentrations $<2 \mathrm{mg} \mathrm{L}^{-1}$ (Florez 1972b). Increasing turbidity can result in larger-scale ide movements, possibly due to reduced foraging efficiency of this visually-oriented predator (Kulíšková et al. 2009), and could be a contributing factor to declines or reduced abundance in ide populations at heavily polluted or eutrophic sites in various regions across the species' European range (e.g. Anttila 1973; Penczak and Koszalinska 1993; Kulíšková et al. 2009; Skovrind et al. 2016). The sensitivity and intolerance of ide to pollution has led to suggestions of the species being used as a bioindicator with regard to water quality (reviewed in Witeska et al. 2014).

The ide is a migratory (potamodromous) species, undergoing annual upstream spawning migrations in early spring (Ciolac 2004), although in the Baltic Sea and nearshore freshwater river basins it is facultatively anadromous, mostly spawning in fresh (Cala 1970; Eriksson and Müller 1982; Rohtla et al. 2015a) and possibly brackish waters (Erm et al. 1970). After spawning, the adults return to their feeding grounds and later to overwintering habitats in deeper waters from where they move very little (e.g. Kulíšková et al. 2009). Early larval stages 
are subject to downstream drift (e.g. Zitek et al. 2004a, 2004b), and can represent a major proportion of the larvae found in freshwater tidal estuaries (Scheffel and Schirmer 1991) - a relatively common phenomenon of many European riverine fish species (Pavlov 1994). There are few studies that have examined the habitat use and migratory behaviour of wild ide inhabiting fresh (Winter and Fredrich 2003; Kulíšková et al. 2009) and brackish waters (Cala 1970; Eriksson and Müller 1982; Rohtla et al. 2015a).

Although ide is often considered to have a limited home range, it can undertake relatively short migrations (Järvalt et al. 2003) with movements up to $278 \mathrm{~km}$ and a mean linear home range of $53.5 \mathrm{~km}$, as reported in the Netherlands (de Leeuw and Winter 2006, 2008). For example, upstream migrations have been documented through fish ladders (Lelek and Libosvárský 1960), though in the cited case the ide represented only 1\% of the fish observed. Genetic analyses have suggested that in a $120 \mathrm{~km}$ stretch of the River Elbe, the resident ide stock could be considered as a single panmictic unit, emphasising the high migration capacity of the species' populations that inhabit the large lowland rivers of central Europe, especially during the spawning period (Wolter et al. 2003). Indeed, great variability in home range area and spawning migration distance, with co-existing highly mobile and mainly sedentary individuals, have been reported for individual adult ide in the middle reaches of the rivers Elbe (Germany) and Vecht (Netherlands) (Winter and Fredrich 2003). Spawning-site fidelity has been detected in all tagged ide in the River Vecht, whereas individuals in the River Elbe moved between 60 and $90 \mathrm{~km}$ downstream for spawning and tended to use new spawning sites each year (Winter and Fredrich 2003). Variability in spawning migration patterns observed in different regions across the native range of ide reflect differences in river conditions and may indicate a degree of spawning site plasticity (Kulíšková et al. 2009). In the rivers Elbe and Vecht, differences were also observed in the autumnal upstream migrations to wintering habitats (Winter and Fredrich 2003). A similar study carried out on the upper reaches of the 
River Elbe found that turbidity significantly increased diurnal movement and home range area, with spawning migrations of $3-100 \mathrm{~km}$ always followed by return migrations to the initial tagging location (Kulíšková et al. 2009) - a pattern that is uncommon for most other migratory cyprinids (Smith 1991).

In fresh waters, ide movement and dispersal appear to be limited by water retention structures. For example, movement distances of ide in the weir-regulated Meuse River in the Netherlands were shorter than those in free-flowing rivers, and few individuals were observed to migrate further upstream in rivers with fishways at the weirs and hydropower stations (de Leeuw and Winter 2008). The impediment that these structures exert on spawning migrations is one of the mechanisms attributed to population declines of ide and other rheophilic cyprinids in northern Europe (Peňáz and Jurajda 1996; Povž 1996; Schiemer et al. 2004).

Spawning runs of anadromous ide in the vicinity of Øresund Strait (Baltic Sea) may extend up to $50 \mathrm{~km}$ inland within the River Kävlinge, Sweden (Cala 1970). Also, the few Baltic Sea re-captures of ide tagged in a small river near Umeå (Sweden) were all widely distributed along the coast, suggesting that individuals can cover considerable distances in brackish waters (Johnson 1982). Furthermore, an analysis of the genomic structure of ide populations in the western Baltic Sea region suggested that ide can migrate not only along the coastline, but that they may also cover significant distances (e.g. up to $55 \mathrm{~km}$ ) across deeper waters of the Baltic Sea (Skovrind et al. 2016). On the Estonian coast of the brackish eastern part of the Baltic Sea (salinity $\sim 4-7$ ), 72\% of the sampled ide had hatched in semi-enclosed, brackish bays that are flushed with fresh water during spring spawning, with only $28 \%$ of the individuals hatched in truly lotic environments (Rohtla et al. 2015a). The young-of-year (YoY) of anadromous Baltic ide migrate to the sea during the first two months of life (Rohtla et al. 2015a) or after one year in fresh water (Cala 1970). This difference in age at emigration most likely reflects acclimation to different adult rearing salinities, as migration to higher salinities requires larger body sizes 
in order to withstand increases in osmotic pressure. Following their migration to the sea, juvenile ide subsequently perform annual non-spawning freshwater migrations together with the spawning adults in the spring (Rohtla et al. 2015a).

\subsection{Ontogeny and growth}

\subsubsection{Early development and growth}

The eggs of ide are quite sensitive to environmental perturbations during their initial days of development, with survival as low as $15 \%$ in lotic conditions, which drops even further to $1 \%$ in lentic conditions with abundant vegetation (Pliszka 1953). Growth rates of ide larvae are amongst the highest in cyprinids, with relative weight gain being rapid during the first year of life and then decreasing with age (Zhukov 1965; Rohtla et al. 2015b). A laboratory study on early ontogeny suggested the presence of eleven different stages in the post-hatch embryonic, larval, and juvenile periods (Kupren et al. 2015). Standard lengths (SL) of ide free embryos at hatching and at two and six months post-hatch are 5-6 mm, 16-24 mm, and $45-57 \mathrm{~mm}$, respectively (Cala 1970; Koblickaya 1981; Järvalt et al. 2003). In earthen aquaculture ponds in Flanders (Belgium), mean SL of YoY fish reared on natural foods at the end of the growth season was $88 \mathrm{~mm}$ at densities between 200 and $500 \mathrm{~kg} \mathrm{ha}^{-1}$. In low density ponds (i.e. $6.9-$ $12.5 \mathrm{~kg} \mathrm{ha}^{-1}$ ), SL after the first growth season was up to $187 \mathrm{~mm}$ (Verreycken 1998). Further, in the River Kävlinge (Sweden), growth of YoY ide has been recorded to end in November (Cala 1970).

Somatic growth rates are relatively fast up to sexual maturation, after which they decrease, with annual growth increments becoming minimal after age 10 years (Rohtla et al. 2015b). This makes body length/weight a poor predictor of age in larger individuals (Cala 1970; Rohtla et al. 2015b), with otolith weight being a more robust (indirect) parameter (Rohtla et al. 2015b). There are no reported differences in growth rate between male and female ide (Cala 1970; Erm and Kangur 1985). The largest recorded SL is $665 \mathrm{~mm}$ (Witkowski et al. 1997) and total body 
mass $5.2 \mathrm{~kg}$ (Finnish Fishing Journal 1973). Total body mass for ide rarely exceeds $3.0 \mathrm{~kg}$ in the Baltic Sea and its tributary basins (Cala 1970; Järvalt et al. 2003; M. Rohtla, unpublished data).

\subsubsection{Age and growth}

Age of ide has historically been estimated from scale annuli (Cala 1970; Järvalt et al. 2003), though otolith thin sections have recently been used (Rohtla et al. 2015b). The formation of scales commences at 18-21 mm SL when ide are 40 to 50 days old (Ristkok 1970; Cala 1971a). If accurate (annulus-based) age estimates are desired, then stained otolith thin sections have been recommended over scales, especially when dealing with older individuals, with the only disadvantage being represented by the destructiveness of the method (i.e. otolith extraction requires sacrifice of the fish: Rohtla et al. 2015b; see also Vilizzi 2018). The maximum recorded age for ide is 29 years (Rohtla et al. 2015b), with mean age of (anadromous) spawning stocks usually ranging 6-11 years (Cala 1970; Erm and Kangur 1985; Rohtla et al. 2015b). The oldest specimens of ide from the River Danube and its tributaries in Slovakia were nine years old, although 1-3 year old juveniles dominated in populations from various habitats, including the main channel, side arms and tributaries, backwaters, and/or small isolated oxbows (Balon 1962). The oldest golden orfe in the introduced population of Štrbské Pleso Lake was 11 years old (Balon and Žitňan 1964).

Based on length-at-age data from the native and introduced ranges of ide (Tables A1 and A2; see also Appendix: Age and growth modelling), global growth in body length is asymptotic with an estimated $\mathrm{SL}_{\infty}=422.4 \mathrm{~mm}$ (Table 1 ), and is characterised by large variation within year classes (Fig. 2a) - noting that only recently have ide individuals been aged over 15 years (i.e. up to 29: Nicolaisen 1996; Rohtla et al. 2015b). Lotic populations achieve a larger size relative to lentic ones (Fig. 2b), and the same occurs in arid relative to continental and temperate climates (Fig. 2c), whereas under cold climates asymptotic size decreases 
progressively in areas with warm, temperate and cold summers (Fig. 2d). Condition factor for ide has been reported to vary from 0.46 to 3.51 (Table 2). The reported total length-weight relationship parameters for ide are provided in Table 3.

\subsection{Reproduction}

\subsubsection{Sexual maturation, gonad development, and fecundity}

In Europe, age at maturity varies with increasing latitude from 1 to 10 years (Table 4). Males usually mature one year earlier than females (Cala 1971b; Balon 1962; Koopmans and van Emmerik 2006), though no differences in age at maturity have been observed among sexes in Estonia (Oolu 1970; Haberman et al. 1973). Also, gonads of older and larger ide tend to ripen earlier in the season than gonads of smaller fish or first-time spawners (Cala 1971b). The cycle of male gonad development in Lake Võrtsjärv (Estonia) commences in July and reaches its final stage by October/November, when the gonado-somatic index (GSI) is between $1.2 \%$ and $1.8 \%$, increasing with body size. Males can render milt prior to spawning and continue to produce milt for relatively long periods (Cala 1971b; Järvalt et al. 2003). In females, ovaries are located only in the dorsal area of the body cavity, apparently associated with the swim bladder by connective tissue. In juveniles, immature ovaries are cylindrical, but with age become dorso-ventrally slightly flattened. When sexual maturity is reached, the ovaries extend into the proximal direction of the abdominal cavity. The entire body cavity of spawning ide, except for the space occupied by internal organs, is then filled by the ovaries (Cala 1971c).

Ovary development in the ide commences in July of the year prior to spawning and reaches its final level by October/November when GSI can be between $15 \%$ and $30 \%$, increasing with body size (Cala 1971b; Järvalt et al. 2003). In female ide from the River Danube (at Paks, Sződliget, and Dunakiliti in Hungary), GSI in March was $7 \%$, increasing to $15.6 \%$ in early May, decreasing to $10 \%$ in late May, and then to $<1 \%$ in July and August, and increased again to about $6 \%$ in September-November (Lefler et al. 2008). Two weeks before the onset of 
spawning, the ovaries of ripening females contain three types of developing eggs (Cala 1971c): unripe (diameter $=0.1-0.5 \mathrm{~mm}$, to be spawned in subsequent years), ripening $(0.5-1.3 \mathrm{~mm})$, and ripe $(1.3-1.85 \mathrm{~mm})$. In the River Danube, the transition of oocytes from the stage of primary growth to cortical alveoli in ide was observed in July-August, with vitellogenesis initiated already in August-September (Lefler et al. 2008). In March, the ovaries ide from the River Danube contained oocytes in the stage of vitellogenesis only, whereas in July no vitellogenic oocytes were present, and oocytes in the stage of primary growth were much more numerous than those at the stage of cortical alveoli. In September, only a few oocytes in the stage of cortical alveoli were present, with those in primary growth and vitellogenesis being almost equal. In October, oocytes in the stage of cortical alveoli remained low, with vitellogenic oocytes being predominant (Lefler et al. 2008).

The diameter of mature eggs varies from 1.4-2.3 mm (Table 5), and egg size does not appear to depend on female size (Järvalt et al. 2003). Ide of age 4 years from Lake Mosąg (Poland) produced smaller eggs $(1.28 \mathrm{~mm})$ than 5-9 year-old conspecifics $(1.44-1.57 \mathrm{~mm})$ (Targońska et al. 2012). The oldest individuals in the population either produced the highest percentage of both dead embryos during incubation and morphological abnormalities in hatched larvae, or they failed to produce eggs at all (Targońska et al. 2012).

Absolute fecundity of female ide is highly variable (Table 5) and most likely depends on growth rate, size at maturity, life-history type, and/or geographic origin. The most distinct increase in absolute fecundity is observed between the fourth and seventh year of life (Targońska et al. 2012). In the River Kävlinge (Sweden), absolute fecundity was better correlated with body mass rather than body length, ovary weight or age (Cala 1971b). Relative fecundity (per gram of eviscerated weight) was 65-124 eggs in Lake Võrtsjärv, Estonia (Pihu 1960), and 153-182 eggs in the rivers Nasva and Kasari (Erm and Kangur 1985). 


\subsubsection{Reproductive behaviour}

Spawning in ide occurs during one clear seasonal peak per year in the early spring (Lefler et al. 2008). Depending on location, this can occur anytime between February through June (Vriese et al. 1994; Dulmaa 1999; de Leeuw and Winter 2008; Witeska et al. 2014) and is triggered by increasing water temperatures. A similar time frame has been reported for locations of the River Danube in Hungary (Lefler et al. 2008). In the Ural and west and central Siberia regions (Russia), Estonia, Kazakhstan, Lithuania, and Sweden, spawning takes place between the beginning of March and the beginning of June at water temperatures of $4{ }^{\circ} \mathrm{C}$ to $13{ }^{\circ} \mathrm{C}$ (Ereshchenko 1956; Zhukov 1965; Cala 1970; Zhuravlev and Solovov 1984; Virbickas 2000; Järvalt et al. 2003; Petlina and Romanov 2004).

Spawning usually commences a few days after ice break-up and generally lasts only 3-9 days under stable temperatures (Cala 1970; Zhuravlev and Solovov 1984; Järvalt et al. 2003). Males reach the spawning grounds earlier and depart later than females (Cala 1970). Sex ratio during spawning can be slightly in favour of either females or males, but usually does not significantly deviate from a 1:1 ratio as in the Baltic Sea (Cala 1970; Oolu 1970; Erm and Kangur 1985). A ratio of 1:3.67 (F:M) has been documented in fresh waters of Serbia (Lujić et al. 2013). Larger individuals usually spawn first (Cala 1970), with spawning occurring in the vegetated and marshy zones of lakes (Popov et al. 2005) or in river backwaters and flood plains (Zhukov 1965; Petlina and Romanov 2004). Spawning habitat requirements include water velocities of $0-60 \mathrm{~cm} \mathrm{~s}^{-1}$ at depths of $0-100 \mathrm{~cm}$ over substrata that can contain stones, coarse gravel, fine and coarse sand (Vriese et al. 1994), but also pebbles covered with algae, flooded grass, and plants associated with sand (Mann 1996). Spawning in the flooded shallow regions of lakes and rivers usually occurs at depths of $0.5-1.0 \mathrm{~m}$, mainly on dead vegetation (Haberman et al. 1973; Zhuravlev and Solovov 1984; Erm and Kangur 1985). In the brackish coastal waters of Estonia, spawning occurs on algae (e.g. Chara sp.) or sandy/stony bottom (Oolu 1970; Erm 
and Kangur 1985). Spawning occurs during both day and night (Cala 1970; Petlina and Romanov 2004). Adhesive eggs attach to vegetation, gravel or other substrata (Cowx and Welcomme 1998). Ide do not guard their eggs once laid, and the duration of the embryonic development depends on ambient water temperatures and lasts about two weeks at $10-12{ }^{\circ} \mathrm{C}$ (Järvalt et al. 2003). The hatched embryos stick to macrophytes and start active swimming shortly before absorption of the yolk sac at 6.1-6.9 mm SL (Järvalt et al. 2003). The nursery habitat of ide has been described as having velocities of $0-10 \mathrm{~cm} \mathrm{~s}^{-1}$ at depths of $0-100 \mathrm{~cm}$ (Vriese et al. 1994).

Reproductive success in ide depends on water temperature and level during spring spawning. Springs without steep drops in water temperature, accompanied by high and stable water levels throughout the season, usually result in successful spawning events (Cala 1970; Florez 1972a; Järvalt et al. 2003). Preferred temperatures for spawning are variable depending on location, though ide typically require cooler waters. For example, although a preferred temperature range of $15.7-19^{\circ} \mathrm{C}$ for spawning has been reported (Kupren et al. 2010), temperatures above $16^{\circ} \mathrm{C}$ may result in reduced ovulation success (Targońska et al. 2011). Variability in preferred spawning temperatures indicates that ide is highly plastic in spawning requirements (Kucharczyk et al. 2008; Winter and Fredrich 2003). Deficiency in oxygen levels (e.g. due to pollution) during early development (cf. eggs and larvae), along with predation, can also affect spawning success (Cala 1970, Florez 1972b).

Where they co-occur, ide can occasionally hybridise with common bream Abramis brama, asp Leuciscus aspius, common carp Cyprinus carpio, dace Leuciscus leuciscus, roach Rutilus rutilus, and rudd Scardinius erythropthalmus (Schwartz 1972, 1981; Kopiejewska et al. 2003; Yadrenkina 2003; Witkowski et al. 2015). It is not clear whether these hybridisations have had negative impacts on parental species in the wild. 


\subsection{Diet}

The ide is generally described as omnivorous (Cala 1970; Brabrand 1985; Järvalt et al. 2003), though occasionally as herbivorous (Winfield and Nelson 1991), with a stable isotope study conducted in Lake Baikal (Siberia) suggesting that in the littoral zone the species is both detritivorous and planktivorous (Katzenberg and Weber 1999). The range of food items encompasses molluscs, crustaceans, bryzoans, insects, fish eggs and larvae, as well as age 0+ and $1+$ juveniles of cyprinids, higher plants (macrophytes), seeds, detritus, rotifers, algae, and insect larvae (Cala 1970; Brabrand 1985; Rask 1989). These studies all suggest a broad and opportunistic diet, encompassing both animal and plant taxa (Table A3) and varying according to ontogeny and season (Cala 1970), with the shift to plants apparently influenced strongly by the intensity of inter- and intra-specific interactions and by the availability of animal prey (Brabrand 1985).

The onset of exogenous feeding in ide larvae is at 6.1-6.9 $\mathrm{mm}$ SL in the wild (Petlina and Romanov 2004) and at 6.5-7.2 mm SL under controlled (laboratory) conditions (Kupren et al. 2015). Larvae of $8.9-16.2 \mathrm{~mm}$ SL were found to feed on zooplankton and benthic invertebrates, whereas juveniles (20.3-28.4 mm SL) fed on insects and plant material (Petlina and Romanov 2004; Zygmunt 1999), and in Lake Võrtsjärv (Estonia) YoY ide mainly consumed Trichoptera, Ephemeroptera, and Chironomidae (Järvalt et al. 2003). Sub-adults and adults feed on plant material and benthic invertebrates, with larger individuals also preying on fishes (Cala 1970; Brabrand 1985; Rask 1989; Järvalt et al. 2003), including juvenile bighead carp Hypophthalmichthys nobilis, roach, and common bleak Alburnus alburnus (Sanft 2015). In the River Kasari (Estonia), the diet of adult ide comprised Asellus sp., Trichoptera, Diptera, Coleoptera, and Chironomidae larvae (Järvalt et al. 2003). In the River Yenisei (Siberia), the main prey item of adults was represented by Mollusca (Dolgin 2009), whereas in the upper River Ob (Siberia), prey items included Coleoptera, Trichoptera, Odonata, and Chironomidae 
(Zhuravlev and Solovov 1984). In the upper River Volga basin, Dreissenid mussels are important food items for benthophagus fish species, including ide, the latter having been found to consume the largest-sized mussels amongst fish in the region (Shcherbina and Buckler 2006). In the brackish coastal waters of Estonia, smaller ide mainly feed on Ostracoda, Amphipoda, and small snails, whereas larger specimens feed mostly on clams and the crustacean Saduria entomon. Occasionally, small fishes such as ninespine stickleback Pungitius pungitius and eggs and young of whitefish Coregonus lavaretus are also consumed (Oolu 1970; Järvalt et al. 2003).

Seasonal changes in the diet of ide vary according to prey availability (Tyutenkov 1956; Cala 1970; Brabrand 1985). For example, in Lake Kurgaldzhin (Kazakhstan), sub-adults and adults mainly preyed upon Gammarus sp. (53\%) in spring, whereas macrophytes represented only $5 \%$ of the biomass intake in spring, which increased to $95 \%$ in summer, and with Chironomidae becoming important in autumn (Tyutenkov 1956). In the River Kävlinge (Sweden), plant material (such as Lemna minor and Potamogeton sp.) and seeds were also mainly eaten in summer and early autumn (Cala 1970; Brabrand 1985). Fish eggs were present in the diet in May only, and YoY fishes in October and November (Brabrand 1985). In winter, ide do not stop feeding (Järvalt et al. 2003), with Oligochaeta representing a main winter dietary item in the River Kävlinge (Cala 1970). In mesotrophic lakes of southeast Norway, consumption of macrophytes by ide increased when animal food supply was scarce (Braband 1985). In that study, ide was observed to feed upon various marsh plants (e.g. water horsetail Equisetum fluviatile) as well as upon clasping pondweed Potamogeton perfoliatus in shallow littoral areas of the lakes. Also, diet shift to plants appeared to be strongly influenced by the supply of animal food items and the intensity of interspecific competition with roach.

The ide is a visually-oriented feeder and consequently experiences reduced foraging success where turbidity is high (i.e. visibility is low) (Kulíšková et al. 2009). In addition, the ide is 
considered to be a hearing specialist (cf. ostariophysian fishes), such that hearing may also play a role in prey localisation (Schuijf et al. 1977).

\subsection{Predators}

All ontogenetic stages of ide are susceptible to some level of predation. The eggs and larvae of ide are heavily predated by threespine stickleback Gasterosteus aculeatus, even driving the local extinction of ide populations in Norway (Nicolaisen 1996). Juvenile ide are susceptible to predation by piscivorous species of fish including pikeperch Sander lucioperca and northern pike Esox lucius (Ciesla and Kaczkowski 2004), and the Amur catfish Silurus asotus also has been listed as a predator of ide (www.cabi.org/isc/datasheet/77315). In the River Lena (Siberia), the absence of ide in some stretches was postulated to be the result of a high density of predators, dominated by the taimen Hucho taimen - a large salmonid native to the region (Holčík 1984). It has also been suggested that predation by brown trout Salmo trutta was likely responsible for the decreases of ide abundance following stream water quality improvement (Eklöv et al. 1998). The ide is most likely to be predated at small size (i.e. as juveniles), whereas larger individuals reach a size refuge from gape-limited predators (Diekmann et al. 2005). Finally, northern pike can reportedly prey on both juvenile and adult stages of ide (www.cabi.org/isc/datasheet/77315).

The ide is also susceptible to predation by piscivorous birds such as great cormorant Phalacrocorax carbo sinensis and osprey Pandion haliaetus. In Norway, ide are vulnerable to predation by ospreys, as evidenced by the significant proportion (i.e. 32\%) of ide in the diet of these birds in some locations (Swenson 1979). Cormorant predation on ide has been observed in Estonia (Vetemaa et al. 2010), the Netherlands (Veldkamp 1995), and the Czech Republic (Kortan et al. 2008), where fishpond losses of ide were attributed to cormorant predators. Maximum prey size of cormorants is $\sim 1 \mathrm{~kg}$ and, since most adult ide typically weigh $>1 \mathrm{~kg}$, 
adult ide might escape predation by cormorants in Estonian coastal waters (Vetemaa et al. 2010).

\subsection{Pathogens and parasites}

Spring Viraemia of Carp (SVC) is the most serious viral disease to which ide are susceptible (Dixon et al. 1994), and this is regarded as a notifiable disease by the Office International des Epizooties (OIE). Transmission of SVC is usually through introduction of fish infected with the virus. In recent years, the emerging disease koi herpesvirus CyHV-3 (KHV) has spread worldwide, causing significant mortalities amongst common carp and its ornamental varieties, and has also been designated as notifiable by the OIE. Whilst ide do not appear to be susceptible to infection with KHV, Bergmann et al. (2009) isolated the virus from healthy individuals, suggesting that ide may develop carrier status if exposed to this virus. Also, mortalities of cyprinid species caused by a virus with a close serological relationship to pike fry rhabdovirus (PFR) have been reported (Way et al. 2003). Although the ide was not amongst the affected species, it is likely that it is susceptible to this virus, as suggested by experimentally infected ornamental varieties of ide with PFR-80560 (Haenen and Davidse 1993). Bacterial diseases of ide are considered to be non-species specific and include Flexibacter columnaris and Aeromonas punctata (De Charleroy et al. 1993), even though little information exists on mortalities of wild ide caused by bacteria.

The ide can be infected by a wide range of mainly generalist parasites that infect cyprinids and other freshwater fish species (Table A4). The taxonomic diversity of the parasitofauna is high, partly because ide acts as a host to marine parasites e.g. Hysterothylacium aduncum and Pseudoterranova decipiens (Palm et al. 1999) due to its tolerance of brackish water environments (Järvalt et al. 2003). In addition, the diversity of indirectly transmitted parasites that use intermediate hosts such as molluscs and fish reflects the broad dietary spectrum of ide (Järvalt et al. 2003). The species richness of certain groups, particularly protists, platyhelminths 
and nematode larvae, may not be accurate since the records of many ide parasites are by morphological identification, which can be unreliable without molecular confirmation. Ide have the potential to act as a source of parasitic infection, but no more than other cyprinid species. The ide can harbour high numbers of directly transmitted parasites, such as the crustacean Ergasilus sieboldi, which can cause pathology in wild fish populations (Alston and Lewis 1994). The ide also acts as an intermediate host for parasites of veterinary and medical importance such as the liver fluke Opisthorchis felineus (Izyumova 1987) and the highly pathogenic eel swimbladder nematode Anguillicoloides crassus (Thomas and Ollevier 1992). Most notably, wild ide in Norway were reported to be infected with Spironucleus vortens (Sterud and Poynton 2002), suggesting that ide could potentially constitute a threat as a reservoir for spironucleosis, which is highly pathogenic to cultured fish. The common ectoparasites Argulus foliaceus and Piscicola geometra can act as mechanical vectors of SVC (Ahne 1985) which has been isolated from ide (Dixon et al. 1994).

\subsection{Threats, conservation and commercial importance}

In rivers across Europe, the ide and other rheophilic cyprinids have experienced declines and in several cases are considered vulnerable or endangered (review in Grift 2001; see also Winter and Fredrich 2003). Within its native range, the ide continues to be threatened by humanmediated impacts such as pollution and eutrophication (Müller 1982; Kulíšková et al. 2009), water retention structures and habitat destruction in rivers (Peňáz and Jurajda 1996; Scholten et al. 2003; Bukelskis and Kesminas 2016), habitat modifications in brackish waters (Veld 1969), non-native species introductions (Zhuravlev and Solovov 1984; Petlina and Romanov 2004), and overfishing (Erm and Kangur 1985). Changes in future climate might also pose a threat, with the species being predicted to suffer from reduced temperature compatibility in its introduced range of England and Wales (Britton et al. 2010). As a result of all these pressures, there is a growing interest in ide aquaculture, particularly in Poland, for the purpose of 
restocking to supplement declining natural populations (Kucharczyk et al. 2008; Kupren et al. 2010). This interest in ide aquaculture is, at least partly, economical as it is derived from current fisheries regulations that force angling associations to stock ide to all water bodies. Interestingly, following the impoundment of the River Warta (Poland), ide was one of the most abundant fish species in the most degraded section of this river, probably due to the absence of large rheophilic fishes (Kruk 2007), hence demonstrating that in some locations ide can prevail under conditions of environmental perturbation and weak competition. Counter-intuitively, long-term stream water quality improvement in southern Sweden has resulted in considerable decline of ide abundance whilst facilitating increases in brown trout Salmo trutta abundance (Eklöv et al. 1998). Whereas, no difference in ide presence has been reported for the River Rhine despite water quality and habitat improvements between 1980-1990 and 2000-2010 (Fedorenkova et al. 2013).

Relatively fast growth rates and large body size make ide a desirable target for commercial and especially recreational fisheries, and as a consequence it is a popular sport fish across Europe (Järvalt et al. 2003; Hickley and Chare 2004; Harzevili et al. 2012). The peak of the commercial importance of ide dates to the 1920-30s in countries such as Estonia and the Netherlands, whereas little is known about the current importance, stock status, and conservation of this species in most other countries. Notably, the ide is currently marked as of 'Least Concern' in the IUCN Red List of Threatened Species (www.iucnredlist.org/species/11884/3312021), although it is classified as being 'Vulnerable' to 'Endangered' in a number of countries across Europe.

In Belgium, the ide is considered an important fish for recreational angling, with ongoing re-stocking programmes in Flemish rivers since the 1990s (1-5 tons $\mathrm{yr}^{-1}$ since 2000), which however have not (yet) resulted in increased abundances (Flemish Freshwater Fish Monitoring Network: H. Verreycken, unpublished data). In Flanders, where the species is currently marked 
as 'Vulnerable' according to the Flemish IUCN Red List (Verreycken et al. 2014), there is a closed angling season for ide from April 16 through May 31. Also, a minimum angling size of $25 \mathrm{~cm}$ (total length: TL) is in force in Wallonia, but not anymore in Flanders.

In Estonia, the ide has historically been an important commercial species with catches of freshwater resident (mainly lakes Peipsi and Võrtsjärv) and anadromous individuals peaking in the 1920-30s and in the 1980s at 54 and 177 tons $\mathrm{yr}^{-1}$, respectively (Järvalt et al. 2003). Currently, catches of 3-5 tons $\mathrm{yr}^{-1}$ are reported from coastal waters (www.agri.ee). Overfishing during the spawning runs has been the main factor responsible for the collapse of anadromous ide stocks in the country (Erm and Kangur 1985). To protect ide stocks in the sea and coastal rivers, a legal minimum size of $38 \mathrm{~cm}$ (TL) and several no-fishing zones have been established. Despite these measures and an almost complete cessation of commercial fishing for ide, most stocks in the coastal sea have not yet recovered from the collapse (Eschbaum et al. 2016). A relatively steep increase in the numbers of juvenile ide has been recorded in recent years (Eschbaum et al. 2016), suggesting that successful spawning seasons, albeit irregular, can result in high densities of sub-adults. Ide is a popular sport fish in Estonia, and recreational anglers from all over the country travel to West Estonia to target anadromous ide from the Baltic Sea during its spawning migration into rivers and semi-closed bays. The number of different anadromous spawning stocks is unknown, but the most abundant runs occur in Hiiumaa Island (Käina Bay and Kõrgessaare region) and in Matsalu and Saunja bays. No re-stocking of ide is currently conducted in Estonia. In the Estonian Red List of Threatened Species, ide is currently marked as 'Data deficient' (http://elurikkus.ut.ee).

In Finland, ide used to be a popular species for household use, but it has fallen into disfavour along with the general decrease in appreciation of cyprinids for human consumption. Some ide are still caught for the market in the Archipelago Sea and the Gulf of Finland as well as in estuaries of the northern Gulf of Bothnia. Ide stocks have been declining locally owing to 
eutrophication, dam building, and water level regulation, and some stocks have even vanished as a result of water acidification. In the Finnish Red List of Threatened Species, ide is currently marked as 'Least concern'.

In Latvia, ide is a common species in coastal waters, but populations are small and the number of rivers inhabited by the species has declined from $\sim 76$ to $\sim 40$ (Birzaks et al. 2011). Landings of ide have decreased in the traditional fishing areas of the coastal waters of the Gulf of Riga (western Latvia), where a minimum legal size of $30 \mathrm{~cm}$ (TL) has been established. In the Latvian Red List of Threatened Species, ide is currently not listed (J. Birzaks, personal communication).

Albeit rare in coastal waters of Lithuania, ide is still common and relatively abundant in the Curonian Lagoon and in the largest rivers of the country, namely the Nemunas and Neris (Virbickas 2000; Bukelskis and Kesminas 2016). Similar to Estonia, a substantial increase in the numbers of juvenile ide has been recorded in the River Nemunas and Curonian Lagoon in recent years, although in other rivers ide abundance has remained unchanged or has decreased (Bukelskis and Kesminas 2016). In the River Nemunas, the relative abundance of ide juveniles varied from 1.1\% to 2.9\% in 2015 (Bukelskis and Kesminas 2016), and in the Curonian Lagoon juveniles comprised $3.1-6.7 \%$ of the entire juvenile fish community of the shore area in 2012 (Repečka et. al. 2012). Ide has never been commercially important in Lithuania, and until the 1980s annual landings rarely exceeded 4 tons $\mathrm{yr}^{-1}$ (mean 2.5 tons). Landings of ide dramatically decreased in the 1990s to $0.2-0.3$ tons $\mathrm{yr}^{-1}$ and even further at the beginning of the $21^{\text {st }}$ century, with mean landings being at just $33 \mathrm{~kg} \mathrm{yr}^{-1}$ (Bukelskis and Kesminas 2016). Some signs of recovery were observed in 2015 , when commercial catches suddenly increased to $419 \mathrm{~kg}$ (Bukelskis and Kesminas 2016), possibly as a consequence of a recently-documented recovery in juvenile ide abundance. Similar to Latvia, a minimum legal size of $30 \mathrm{~cm}$ (TL) has been enforced in Lithuania, even though ide is not enlisted in the Lithuanian Red List of Threatened 
Species. In 2016, a study proposing an ide re-stocking programme for inland water bodies with extinct or nearly extinct ide populations was accepted by the Fisheries Department of The Ministry of Agriculture of the Republic of Lithuania (Bukelskis and Kesminas 2016), and statesupported ide re-stocking started in 2017 with 516,000 YoY individuals released in 2020.

In the Netherlands, considerable quantities of ide were once caught in the brackish water zones of the former Zuiderzee (Veld 1969), but following construction of the Afsluitdijk (or Enclosure Dam), the resulting gradual transition from fresh to salt water of the IJssel estuary (northwestern Netherland) coincided with a decrease in ide catches in Lake IJssel from 6.7 tons in 1935 to 2 tons in 1940 (Veld 1969). Ide is included in the Fisheries Act, which specifies the permitted landing sizes and quantities for all listed species. A closed season for angling exists from April 1 through May 31, but with no minimum angling size. As in Flanders, ide is listed as 'Vulnerable' in the IUCN Red List for the Netherlands (de Leeuw et al. 2005), but is not included in the new Red List anymore (Spikmans and Kranenbarg 2016). Also, ide is not included in the Annexes of the Habitats Directive or the Dutch Flora and Fauna Law.

In Poland, the ide is considered an important angling species (Witkowski et al. 1997), with a minimum legal size of $25 \mathrm{~cm}$ (TL). The maximum permitted daily catch is $5 \mathrm{~kg}$ in fresh waters and $10 \mathrm{~kg}$ in marine waters. Levels of total allowable commercial catches in rivers, reservoirs and lakes are established individually for each water body (or river stretch). In 2018, the commercial catches of ide reached almost 1.56 tons, amounting to $0.7 \%$ of total inland fishery landings of all fish species. Recreational catches are much higher and amounted to 31.36 tons in 2017 (Wołos et al. 2020). The only restriction applied to marine commercial fisheries dealt with a minimum legal size of $25 \mathrm{~cm}$ (TL) in the 'western internal waters' (the Szczecin and Kamieński Lagoons). According to the Fishing Monitoring Centre in Gdynia, no ide was recorded in official commercial fishery statistics from marine areas of Poland between 2004 and 2019 (including the Szczecin and Vistula Lagoons). This might be explained by low 
numbers of fish in the environment as well as not reporting ide in the catches by fishers, although some specimens might have been classified as 'other freshwater fishes' or as roach. Additionally, between 2015 and 2017 the catches from fishers' boats shorter than $8 \mathrm{~m}$ were exempted from the obligation of reporting, and individual recreational fishery in Polish marine waters does not have to report catches at all. The Poland Inland Fishery Act imposes an obligation to re-stock rivers with fish including the ide, but for inspection authorities the origin of fish is not taken into consideration. In $2018,6,135,000$ yolk-sac larvae with $14,482 \mathrm{~kg}$ of autumn juveniles $(1,266 \mathrm{~kg}$ age $1+$ and $37,232 \mathrm{~kg}$ age $2+)$ and $140 \mathrm{~kg}$ of mature fish were released to rivers and open lakes (Mickiewicz et al. 2020). In the Gulf of Gdansk, where the ide was caught by anglers in the vicinity of Gdynia in the 1960s (M. Skóra, unpublished data), the ide must have been more abundant in the past but is now a rare species (Skóra 1996). Between 2005 and 2007, the share of ide numbers and mass in the catches at the mouth of the coastal River Reda amounted to less than $0.01 \%$ and $0.04 \%$, respectively (Skóra 2015). The ide is very rare also in the Vistula Lagoon, where in 2001 and 2012 the proportion in fyke nets and nordic gill nets was $0.05 \%$ and $<0.01 \%$, respectively (Nermer et al. 2012). A similar situation was observed in the Szczecin Lagoon, where the percent of ide in fyke-net and gillnet catches amounted to $\sim 0.12 \%$ and $\sim 0.04 \%$, respectively (Wawrzyniak et al. 2017). In the Międzyodrze wetlands (the $28 \mathrm{~km}$ stretch of the most downstream part of the lower River Odra), the ide is considered a common species. Between 1952 and 2002, mean catches of the ide reached $915 \mathrm{~kg}$ annually and amounted to $0.62 \%$ of the total catch in that area (Neja 2011). For some inland rivers, a considerable increase in both abundance and biomass has been observed in recent decades (Kruk et al. 2017; Penczak et al. 2017). According to the Polish Red List of Fishes (Witkowski et al. 2009), the ide is of 'Least concern' in inland waters, but 'Vulnerable' in the coastal rivers of the Baltic Sea. 
In Slovakia, the ide used to be a relatively important fish species for freshwater commercial fisheries in the $1950 \mathrm{~s}$, representing $7.9 \%$ ( $\sim 22$ tons) of the total catch of the State Fishery in 1955-1958 (Balon 1962). In that period, ide was considered the most popular cyprinid species after common carp, and it also contributed considerably to overall catches of recreational anglers. Nevertheless, large-scale monitoring data for 2011 and 2020 suggest that ide populations have declined in most Slovak rivers (V. Kováč, unpublished data), except for the Danube, where it still represents a relatively abundant fish species (Bammer et al. 2015).

In Sweden, the ide is rarely captured in different monitoring areas across the country, but there does not seem to have been any overall decline since 2001 . Therefore, the ide is currently not included in the Swedish Red List of Threatened Species. In the commercial coastal fishery, the species' catches are very low and without any identifiable trend since 1999.

\section{Potential invasiveness and ecological impacts in non-native regions}

Owing to its relatively high growth rate and large body size (Rohtla et al. 2015b), the ide is an attractive species for introductions outside its native range, being a popular ornamental fish and a target species for anglers in many countries (e.g. Järvalt et al. 2003; Hickley and Chare 2004). Once introduced, the ide has so far not demonstrated itself to be invasive (e.g. in the USA, New Zealand, England). That is, despite repeated introductions outside of its native range, there is little evidence that the species has established self-sustaining populations or spread elsewhere. Indeed, the ide has been described as 'local and rare' (Maitland 1972), though present in seven of the nine regions of England (Copp et al. 2007). A lack of demonstrated invasive nature and the importance of ide as an ornamental species are the reasons why it was not included in legislation for regulating non-native fishes in England \& Wales, namely the Import of Live Fish Act 1980 and related orders (Copp et al. 2007). Nonetheless, the ide possesses many attributes associated with species that can acclimate to novel environments, specifically omnivory, longevity, and habitat plasticity (e.g. Cala 1970; 
Rohtla et al. 2015a, b). Furthermore, the scientific literature is devoid of studies, and even claims, of adverse impacts of ide on native species and ecosystems in locations where it has been introduced (www.cabi.org/isc/datasheet/77315).

The potential impacts of ide in its introduced range include competition and disease transmission, though of these impacts the most difficult to demonstrate is likely to be competition. The most probable competitors would presumably be other bottom-feeding species, especially other cyprinids with functional similarity (e.g. dace and chub Squalius cephalus). The ide can host infectious agents (SVC) or act as carrier (KHV) of viral diseases and parasites (see Section 2.8: Parasites and pathogens), and therefore stocked ide can act as a vector for the infection of local fish populations. For example, Ergasilus sieboldi is a common parasite of ide in its native range (Sobecka et al. 2004; Rusinek 2007), but E. sieboldi is usually non-native to the locations where the ide has been introduced, such as in England (Kennedy 1975). Furthermore, ide can be the paratenic host for Anguillicoloides crassus (Thomas and Ollevier 1992), which means that careless translocations of infected ide can potentially introduce this swim-bladder parasite to regions where this species was previously not present. The ide is generally an omnivorous feeder of most abundant food items, and its diet shifts largely with ontogeny, seasonality and food availability (e.g. Cala 1970; Brabrand 1985; Järvalt et al. 2003). Recent outdoor experimental studies to test for non-native fish competition with native fishes found limited and potentially unimportant changes in the diet and trophic position in native fishes following the introduction of omnivorous introduced fishes, specifically pumpkinseed (Copp et al. 2017) and sunbleak Leucaspius delineatus (Bašić et al. 2018). As such, further study is needed to determine whether non-native ide exerts competitive pressure on native fishes under natural or near-natural conditions.

There is contrasting information on the sensitivity of ide to environmental perturbations. Habitat improvements that have been conducted following environmental perturbation have 
had positive (Kruk et al. 2017), neutral (Fedorenkova et al. 2013), or even negative (Eklöv et al. 1998) effects on ide abundance. For example, in the River Warta (Poland), ide responded rather positively to perturbations, prevailing even when other large rheophilic species were absent (Kruk 2007). The latter should be considered as a rare example, as ide populations mostly suffer under environmental perturbations (e.g. Müller 1982; Scholten et al. 2003; Bukelskis and Kesminas 2016; M. Rohtla, personal observations), which would potentially limit population growth and subsequent invasiveness. Under controlled laboratory conditions, early life stages of ide have demonstrated good acclimatisation and tolerance to increasing water temperatures (Florez 1972a; Kupren et al. 2010). The latter suggests that ide may be adaptable to climate change-driven increases in temperature, but this does probably not give an advantage to ide compared to other cyprinids since they have similar temperature tolerances. For example, the abundance of vimba Vimba vimba has increased tremendously in the Baltic Sea of late, whereas the numbers of ide have increased only slightly.

Once a localised breeding population of ide has successfully established itself in a novel environment, the species' demonstrated long-distance movements in its native range indicate that it can potentially disperse to a wide geographical area (Winter and Fredrich 2003; Kulíšková et al. 2009; Rohtla et al. 2015a). This means that new regions can be colonised relatively rapidly in a given water course, but evidence for this is lacking. Furthermore, as the salinity tolerance of ide is relatively high (van Beek 1999; Skovrind et al. 2016), there is also some potential for colonising new, closely-located water courses through marine and brackish water pathways when suitable conditions are present (e.g. during large riverine runoff). Although the possibility of such events is largely unknown, it may be most plausible in regions where salinity levels are projected to decrease due to climate change (e.g. Durack et al. 2012). As the ide can also be relatively long-lived (Rohtla et al. 2015b), introduced populations could potentially withstand the occasional environmental perturbations that hinder successful 
reproduction in a given year, as in the case of tench Tinca tinca introduced to Ireland (O'Maoileidigh and Bracken 1989) and of native populations in England (Copp 1997). The potential risks of ide hybridising with native species is likely to be restricted to closely-related native cyprinids (Kopiejewska et al. 2003; Yadrenkina 2003; Witkowski et al. 2015).

In summary, virtually all aspects of the environmental biology of introduced ide require further study, though some initial information is available for native populations on migratory behaviours, diet, diseases, growth, and potential hybridisation with native species. Existing evidence suggests that the ide does not appear to pose an elevated risk of being invasive where introduced outside its native range in Europe. Further afield, the ide may become invasive, such has been observed with another European cyprinid, namely the rudd in North America (e.g. Guinan et al. 2015). In an initial invasiveness risk screening for England \& Wales, the ide attracted an intermediate mean risk score of 20 , which placed it at the lowest extent of the 'high risk' score range for that region (Copp et al. 2009b; Britton et al. 2010). A similar mean score (20.2) and risk ranking was reported for Iberia (Almeida et al. 2013), and a lower score (14.0), albeit still considered as high risk, for Scotland (Vilizzi et al. 2019). Very early on, some North American sources (see Nico et al. 2020) recommended against introductions of the ide to California. Despite these concerns, there has been little study of ide in North America (Nico et al. 2020). There have been, however, reports of benign diseases being imported to the USA from Germany (McAllister et al. 1985). The lack of evidence for demonstrated impacts may appear to corroborate these risk screening outcomes, but this lack of evidence is due to a general lack of study of the impacts of ide rather than from the absence of impacts. As introductions of the ide are likely to continue, given its angling popularity and use as an ornamental species, this propagule pressure could lead to the development of invasive populations in some nonnative locations. The fact that the species is not considered likely to be affected by climate warming (Lehtonen 1996; Britton et al. 2010) could be viewed as either advantageous or 
disadvantageous, depending upon whether or not the risk assessment area is likely to experience a warmer climate in future decades.

\section{Acknowledgements}

Conceived within the framework of an international network initiated with a NATO Science Programme 'Collaborative Linkage Grant' (awarded to GHC), this study was funded jointly through research grants from the UK Department for Environment, Food and Rural Affairs (Defra), the Cefas Science Excellence fund, and the EC Marie Curie programme (to GZ). We thank H. Wei (Pearl River Fisheries Research Institute, China) for assistance with the collation of bibliographic materials.

\section{References}

Ahne W. 1985. Argulus foliaceus L. and Piscicola geometra L. as mechanical vectors of spring viraemia of carp. J Fish Dis 8(2):241-242.

Almeida D, Ribeiro F, Leunda PA, Vilizzi L, Copp GH. 2013. Effectiveness of an invasiveness screening tool for non-native freshwater fishes (FISK) to perform risk identification assessments in the Iberian Peninsula. Risk Anal 33(8):1404-1413 doi:10.1111/risa.12050

Alston S, Lewis JW. 1994. The ergasilid parasites (Copepoda: Poecilostomatoida) of British freshwater fish. In: (eds) Pike AW, Lewis, JW. Parasitic Diseases of Fish. Samara Publishing Ltd, Dyfed, UK, pp 171-188.

Anttila R. 1973. Effect of sewage on the fish fauna in the Helsinki area. Oikos 15:226-229.

Autko BF. 1958. Some data on the growth of ide in the Kuibyshev Reservoir, Tr. Tatar. Otd. VNIORKh 8:263-267. [In Russian.] 
Balon EK. 1962. Zákonitosti rastu dunajského jalca tmavého [Leuciscus idus (L.)] (The growth's legality of the Danube ide [Leuciscus idus (L.)]). Práce Laboratória rybárstva 1:117-151. [In Slovak.]

Balon EK, Žitňan R (1964) Vek a rast v Štrbskom plese aklimatizovaného xantorického jalca tmavého (Leuciscus idus aberr. orfus) [Age and growth of the xanthoric ide acclimatized in Štrba Lake (Leuciscus idus aberr. orfus)]. Sborník prác o Tatranskom národnom parku 7:165-180 [In Slovak.]

Bammer V, György A, Pehlivanov L, Schabuss M, Szaloky Z, Zornig H. 2015. Fish. In: Liška I, Wagner F, Sengl M, Deutsch K, Slobodník J (eds) Joint Danube Survey 3. A Comprehensive Analysis of Danube Water Quality, International Commission for the Protection of the Danube River, pp. 126-139.

Bănărescu P. 1964. Fauna Republicii Populare Romîne (Fauna of the Republic of Romania). Vol. 13, Pisces_-Osteichthyes. Editura Academiei Republicii Populare Romîne, Bucuresti, 962 pp. [In Romanian.]

Barinova A, Yadrenkina E, Nakajima M, Taniguchi N. 2004. Identification and characterization of microsatellite DNA markers developed in ide Leuciscus idus and Siberian roach Rutilus rutilus. Mol Ecol Resour 4(1):86-88. doi:10.1046/j.14718286.2003.00577.x

Bašić T, Copp GH, Edmonds-Brown VR, Keskin E, Davison PI, Britton JR. 2018. Limited trophic consequences of non-native sunbleak Leucaspius delineatus for native pond fishes in experimental ponds. Biol Invas 21(1):261-275. doi:10.1007/s10530-018-1824-y

Bauer ON. 1984. Key to the parasites of the freshwater fishes of the U.S.S.R. Vol. 1. Protozoa,. Nauka, Leningrad, 429 pp. [In Russian.] 
Bauer ON. 1985. Key to the parasites of the freshwater fishes of the U.S.S.R. Vol. 2. Parasitic Metazoa. Part 1. Nauka, Leningrad, 426 pp. [In Russian.]

Bauer ON 1987. Key to the parasites of the freshwater fishes of the U.S.S.R. Vol. 2. Parasitic Metazoa. Part 2. Nauka, Leningrad, 426 pp. [In Russian.]

Berg LS. 1949. Freshwater fishes of the USSR and adjacent countries (AN SSSR, MoscowLeningrad), Vol. 2. [In Russian.]

Berg LS. 1964. Freshwater fishes of the USSR and adjacent countries. Jerusalem: Israel 1116 Program for Scientific Translations Ltd.

Bergmann SM, Schütze H, Fischer U, Fichter D, Riechardt M, Meyer K, Schrudde D and Kempter J. 2009. Detection of koi herpes virus (KHV) genome in apparently healthy fish. Bull Eur Ass Fish Pathol 29(5):145-152.

Birzaks J, Aleksejevs Ē, Strūgis M. 2011. Occurence and distribution of fish in rivers of Latvia. Proceeding of the Latvian Academy Sciences, section B, 65:20-30.

Bogutskaya NG, Naseka AM. 2006. List of agnathans and fishes of the Caspian Sea and rivers of its basin. Caspian Sea Biodiversity Project under umbrella of Caspian Sea Environment Program.www.zin.ru/projects/caspdiv/caspian_fishes.html

Brabrand Å. 1985. Food of roach (Rutilus rutilus) and ide (Leuciscus idus): significance of diet shift for interspecfic competition in omnivorous fishes. Oecologia 66(4):461-467. doi:10.1007/BF00379334

Britton JR, Cucherousset J, Davies GD, Godard MJ, Copp GH. 2010. Non-native fishes and climate change: predicting species responses to warming temperatures in a temperate region. Freshwater Biol 55(5):1130-1141 doi:10.1111/j.1365-2427.2010.02396.x 
Brofeldt P. 1917. Bidrag till kännedom om fiskbeståndet i våra sjöar. Längelmävesi [Contribution to knowledge about the fish stock in our lakes. Längelmävesi]. Finlands Fiskerier 4 [In Finnish.]

Brujenko VP, Movchan YV, Smirnov AI. 1974. Morphoecological characteristics of ide (Leuciscus idus (Linnè) in Kremenchug reservoir. Hidrobiologicheskiy Zhurnal 10:70-79. [In Russian.]

Bukelskis E, Kesminas V. 2016. Scientific background for ide and whitefish (sea form) artificial stocking. Hidrobiologist Society of Lithuania, 37 pp. [In Lithuanian.]

Burnham K, Anderson D. 2003. Model selection and multimodel inference: A practicaltheoretic approach. New York, USA: Springer-Verlag, 488 pp.

Čajka M. 1975. Príspevok k štúdiu veku a rastu jalcov (jalec hlavatý - Leuciscus cephalus L., jalec tmavý Leuciscus idus L. a jalec obyčajný - Leuciscus leuciscus L.) so stredného a dolného toku Hrona so zvláštnym zretel'om na znečist'ovanie [Contribution to the study of the age and growth of heifers (Leuciscus cephalus L., Leuciscus idus L. and Leuciscus leuciscus L.) from the middle and lower reaches of the Hron with special regard to pollution.]. Diplomová práca, Vysoká škola pol’nohospodárska, Nitra, 67 pp. [In Slovak.]

Cala P (1970) On the ecology of the ide Idus idus (L.) in the River Kävlingeån, south Sweden. Reports of the Institute of Freshwater Research Drottingholm 50:45-99.

Cala P. 1971a. Scale formation as related to length of young-of-the-year ide Idus idus and roach Rutilus rutilus. J Zool 165(3):337-341. doi:10.1111/j.1469-7998.1971.tb02191.x

Cala P. 1971b. Size and age at maturity, ripening and fecundity of the ide Idus idus (L.). Reports of the Institute of Freshwater Research Drottingholm 51:31-46.

Cala P. 1971c. The development of the oocytes and seasonal changes in the ovary of the ide Idus idus (L.) in the River Kävlingeån, South Sweden. Caldasia 10:579-594. 
Carl H (2012) Rimte. In: Carl H, Møller P.R (eds) Atlas over danske ferskvandsfisk. Copenhagen, National History Museum of Denmark, University of Copenhagen, pp 229238.

Cech G, Molnár K, Székely C. 2012. Molecular genetic studies on morphologically indistinguishable Myxobolus spp. infecting cyprinid fishes, with the description of three new species, M. alvarezae sp. nov., M. sitjae sp. nov. and M. eirasianus sp. nov. Acta Parasit 57(4):354-366. 10.2478/s11686-012-0045-2

Chadderton WL. 2003. Management of invasive freshwater fish: striking the right balance! Proceedings of a workshop hosted by Department of Conservation, 10-12 May 2001, Hamilton, pp. 71-83.

Chan FT, Beatty SJGilles AS Jr, Hill JE, Kozic S, Luo D, Morgan DL, Pavia RTB Jr, Therriault TW, Verreycken H, Vilizzi L, Wei H, Yeo DCJ, Zeng Y, Zięba G, Copp GH. 2019. Leaving the fishbowl: the ornamental trade as a global vector for freshwater fish invasions. Aquatic Ecosyst Health 22(4):417-439. doi:10.1080/14634988.2019.1685849

Ciesla M, Kaczkowski Z. 2004. Influence of rearing method on ide Leuciscus idus L. juvenile survival under pike and pikeperch predation. J Fish Biol 65(S1):327. doi:10.1111/j.00221112.2004.00559ae.x

Ciolac A. 2004. Migration of fishes in Romanian Danube river $\left(\mathrm{n}^{\mathrm{o}}\right.$ 1). Appl Ecol Environ Res 2(1):143-163.

Clavero M, García-Berthou E. 2006. Homogenization dynamics and introduction routes of invasive freshwater fish in the Iberian Peninsula. Ecol Appl 16(6):2313-2324. doi:10.1890/1051-0761(2006)016[2313:HDAIRO]2.0.CO;2 
Collett R. 1905. Meddelelser om Norges fiske i Aarene 1884-1901 [Announcements about Norway's fishing in the years 1884-1901]. Forh. Vid. Selsk Christiania 8:1-173 [In Norwegian.]

Collier KJ, Grainger NPJ (eds). 2015. New Zealand invasive fish management handbook. Lake Ecosystem Restoration New Zealand (LERNZ; The University of Waikato) and Department of Conservation, Hamilton, New Zealand, 216 pp.

Copp GH. 1997. Importance of marinas and off-channel water bodies as refuges for young fishes in a regulated lowland river. Regul Rivers Res Manage 13(3):303-307. doi:https://doi.org/10.1002/(SICI)1099-1646(199705)13:3<303::AID-RRR458>3.0.CO;2$\mathrm{E}$

Copp GH, Bianco PG, Bogutskaya N, Erős T, Falka I, Ferreira MT, Fox MG, Freyhof J, Gozlan RE, Grabowska J, Kováč V, Moreno-Amich R, Naseka AM, Peňáz M, Povž M, Przybylski M, Robillard M, Russell IC, Stakènas S, Šumer S, Vila-Gispert A, Wiesner C. 2005. To be, or not to be, a non-native freshwater fish? J Appl Ichthyol 21(4):242-262. doi:10.1111/j.1439-0426.2005.00690.x

Copp GH, Stakenas S, Davison PI. 2006. The incidence of non-native fishes in water courses: example of the United Kingdom. Aquat Invasions 1:72-75. doi:10.3391/ai.2006.1.2.3

Copp GH, Templeton M, Gozlan RE. 2007. Propagule pressure and the invasion risks of nonnative freshwater fishes in Europe: a case study of England. J Fish Biol 71(sd):148-159. doi:10.1111/j.1095-8649.2007.01680.x

Copp GH, Britton JR, Cucherousset J, García-Berthou E, Kirk R, Peeler EJ, Stakėnas S. 2009a. Voracious invader or benign feline? A review of the environmental biology of European catfish Silurus glanis in its native and introduced range. Fish Fisher 10(3):252-282. doi:10.1111/j.1467-2979.2008.00321.x 
Copp GH, Vilizzi L, Mumford J, Fenwick GV, Godard MJ, Gozlan RE. 2009b. Calibration of FISK, an invasiveness screening tool for nonnative freshwater fishes. Risk Anal 29(3):457467. doi:10.1111/j.1539-6924.2008.01159.x

Copp GH, Tarkan AS, Masson G, Godard MJ, Koščo J, Kováč V, Novomeská A, Miranda R, Cucherousset J, Pedicillo G, Blackwell B. 2016. A review of growth and life-history traits of native and non-native European populations of black bullhead Ameiurus melas. Rev Fish Biol Fish 26(3):441-469. doi:10.1007/s11160-016-9436-z

Copp GH, Britton JR, Guo Z, Edmonds-Brown VR, Pegg J, Vilizzi L, Davison PI. 2017. Trophic consequences of non-native pumpkinseed Lepomis gibbosus for native pond fishes. Biol Inv 19(1):25-41. doi:10.1007/s10530-016-1261-8

Cowx IG, Welcomme RL (eds). 1998. Rehabilitation of rivers for fish. Food and Agriculture Organization of the United Nations, $260 \mathrm{pp}$.

Davies CE, Shelley J, Harding P, McLean I, Gardiner R, Peirson G.. 2004. Freshwater fishes in Britain - the species and their distribution. Harley Books, Colchester.

De Charleroy D, Noterdaeme L, Verbiest H, Ollevier F, Verreycken H, Belpaire C. 1993. Parasieten en bacteriën van blankvoorn, zeelt en winde bestemd voor uitzetting in Vlaanderen [Parasites and bacteria of roach, tench and ide intended for release in Flanders]. In: Verreycken H (ed.) Studie naar de overleving van pootvis in het Vlaamse gewest [Study on the survival of fish fry in the Flemish region] Instituut voor Bosbouw en Wildbeheer, IBW.Wb.V.R.93.13, pp. 81-83. [In Dutch.]

Diekmann M, Bramick U, Lemcke R, Mehner T. 2005. Habitat-specific fishing revealed distinct indicator species in German lowland lake fish communities. J Appl Ecol 42(5):901909. doi:10.1111/j.1365-2664.2005.01068.x 
Dill WA, Cordone AJ. 1997. History and status of introduced fishes in California, 1871-1996. State of California, The Resources Agency, Department of Fish \& Game, Fish Bulletin 178.

Dixon PF, Hattenberger-Bandouy A-M, Way K. 1994. Detection of carp antibodies to spring viraemia of carp virus by a comparative immunoassay. Dis Aquat Org 19:181-186.

Djikanovic V, Paunović, Nikolić V, Simonović P, Cakic P. 2012. Parasitofauna of freshwater fishes in the Serbian open waters: a checklist of parasites of freshwater fishes in Serbian open waters. Rev Fish Biol Fisheries 22(1):297-324. doi:10.1007/s11160-011-9226-6

Dolgin VN. 2009. Fresh-water molluscs in food of fishes of Siberia. Tomsk State Pedagogical University Bulletin 6:117-120. [In Russian.]

Domrachev PF, Pravdin IF. 1926. Fishes of the Ilmen Lake and the Volkhov River and their commercial significance. In: Material of study of river Volkhov and their basin, Vol. 10. Leningrad, Tipografia “Avioizd-va”, 296 pp. [In Russian.]

Dorovskikh GN. 1997. Results of the study of fishes' parasites in river basins of the North-East of the European part of Russia. Monogeneans (Monogenea). Parazitologiia 31:427-437 [In Russian.]

Dorovskikh GN. 1999. Results of the study of fishes' parasites in river basins of the North-East of the European part of Russia. Nematodes (Nematoda) and proboscis worms. Parazitologiia 33:446-452 [In Russian.]

Dottrens E. 1952. Poissons d'eau douce - es poissons d'eau douce. Tome II: Des siluridés aux cyprinidés. Delachaux et Niestlé, Neuchâtel, 227 pp.

Dukravets GM, Karpov VE, Mamilov N, Merkulov EA, Mitrofanov IV. 2001. Concerning the consistence and distribution of fishes in the Kazakhstan part of the river Chu. Vestnik KazGU, serya biologicheskaya, Almaty 14(2):94-104. 
Dulmaa A. 1999. Fish and fisheries in Mongolia. In: Petr T (ed) Fish and fisheries at higher altitudes: Asia. FAO Fisheries Technical Paper No. 385, 304 pp.

Durack PJ, Wijffels SE, Matear RJ. 2012. Ocean salinities reveal strong global water cycle intensification during 1950 to 2000. Science 336(6080):455-458. doi:10.1126/science. 1212222

Dzika E. 2008. Pasożyty ryb Polski. Przywry monogenetyczne - Monogenea. Polskie Towarzystwo Parazytologiczne, Warszawa.

Eklöv AG, Greenberg LA, Brönmark C, Larsson P, Berglund O. 1998. Response of stream fish to improved water quality: a comparison between the 1960s and 1990s. Freshwater Biol 40(4):771-782. doi:10.1046/j.1365-2427.1998.00370.x

Elvira B. 2001. Identification of non-native freshwater fishes established in Europe and assessment of their potential threats to the biological diversity. Convention on the Conservation of European Wildlife and Natural Habitats, Strasbourg. (Bern\T-PVS 2001\tpvs06e_2001)

Ereshchenko VI. 1956. Ichthyofauna of the Sary-Su River basin. Collection of works on ichthyology and hydrobiology. Alma-Ata: Institut zoologii AN KazSSR, pp 94-123. [In Russian.]

Ergens R. 1988. 2 new and 3 previously described species of the genus Gyrodactylus Nordmann, 1832 from the G. phoxini group (Monogenea: Gyrodactylidae). Folia Parasitol 35(1):23-30. https://folia.paru.cas.cz/pdfs/fol/1988/01/06.pdf

Eriksson LO, Müller K. 1982. The importance of a small river for recruitment of coastal fish populations. In: Müller K (ed) Coastal Research in the Gulf of Bothnia. Dr W. Junk Publishers, The Hague, pp 371-385 
Erm V, Kangur M. 1985. Rannikumere säina saakidest, bioloogiast ja varude kaitsest Eesti NSVs [On the catches, biology and conservation of ide in the Estonian SSR]. Abiks Kalurile 4:7-18. [In Estonian.]

Erm V, Kangur M, Saat T. 2002. Matsalu märgala kaladest ja kalapüügist 1980 aastatel [On fish and fishing in the Matsalu wetland in the 1980s] In: Saat T (ed) Väinamere kalastik ja kalandus. [Väinameri Sea fish and fisheries] Tartu Ülikooli Kirjastus, Tartu, pp. 122-158 [In Estonian.]

Erm V, Rannak L, Sõrmus I, Štšukina I. 1970. Väinamere kalastik [Väinameri fish]. In: Kumari E (ed) Lääne-Eesti rannikualade loodus [Nature of the coastal areas of Western Estonia]. Valgus, Tallinn, pp. 61-80. [In Estonian.]

Eschbaum R, Hubel K, Jürgens K, Rohtla M, Špilev H, Talvik Ü. 2016. Eesti riikliku kalanduse andmekogumisprogrammi täitmine ja analüüs, teadusvaatlejate paigutamine Eesti lipu all sõitvatele kalalaevadele ning teadussoovituste koostamine kalavarude haldamiseks aastatel 2015-2017 [Completion and analysis of the Estonian national fisheries data collection program, placement of scientific observers on fishing vessels flying the Estonian flag and preparation of scientific recommendations for the management of fish stocks in 2015-2017]. Eesti Mereinstituut, Contract No. 4-1.1 / 15 / 20-1 2016 final report www.envir.ee/sites/default/files/akp_2016_rannikumere_kalad_0.pdf

Eszterbauer E. 2002. Molecular biology can differentiate morphologically indistinguishable myxosporean species: Myxobolus elegans and M. hungaricus. Acta Vet Hung 50(1):59-62. doi:10.1556/avet.50.2002.1.8

Fan X, Quan R. 2008. Studies on the biological characters of Leuciscus idus in Sailimu Lake. Journal of Bingtuan Education Institute 18(4):51-52. [In Chinese.] 
Fedorenkova A, Vonk JA, Breure AM, Hendriks AJ, Leuven RSEW. 2013. Tolerance of native and non-native fish species to chemical stress: a case study for the River Rhine. Aquat Invas 8(2):231-241. doi:10.3391/ai.2013.8.2.10

Finnish Fishing Journal. 1973. Suuria kaloja [Large fish]. Suomen Kalastuslehti 8:217-219. [In Finnish.]

Florez F. 1972a. The effect of temperature on incubation time, growth and lethality of embryos, larvae and juveniles of the ide, Idus idus (L.). Reports of the Institute of Freshwater Research Drottingholm 52:50-64.

Florez F. 1972b. Influence of oxygen concentration on growth and survival of larvae and juvenieles of the ide, Idus idus (L.). Reports of the Institute of Freshwater Research Drottingholm 52:65-73.

Freyhof J, Kottelat M. 2008. Leuciscus idus. The IUCN Red List of Threatened Species 2008: e.T11884A3312021. doi:10.2305/IUCN.UK.2008.RLTS.T11884A3312021.en

Froese R, Pauly D (eds). 2019. FishBase. World Wide Web electronic publication. www.fishbase.org, version (12/2019)

Gayanilo FC, Sparre P, Pauly D (2005) FAO-ICLARM Stock Assessment Tools II (FiSAT II). User's guide. FAO Computerized Information Series (Fisheries), No. 8, Revised version, FAO, Rome

Gelnar M, Koubková B, Pláňková H, Jurajda P. 1994. Report on metazoan parasites of fishes of the river Morava with remarks on the effects of water pollution. Helminthologia 31(1/2):47-56.

Golovko VI. 1973. Biology of ide from the Turukhtan River basin. Vopr Bot Zool Pochvoved 1:88-94. [In Russian.] 
Grabda J. 1971. Catalogue of Polish parasite fauna. Part II. Parasites of fishes and cyclostomates. PWN, Warszawa.

Grabda-Kazubska B, Pilecka-Rapacz, M. 1987. Parasites of Leuciscus idus (L.), Aspius aspius (L.) and Barbus barbus (L.) from the River Vistula near Warszawa. Acta Parasitologica Polonica 31:219-230.

Grabda-Kazubska B, Okulewicz A. 2005. Pasożyty ryb Polski. Nicienie - Nematoda [Polish fish parasites. Nematodes - Nematoda]. Polskie Towarzystwo Parazytologiczne, Warszawa.

Grift RE. 2001. How fish benefit from floodplain restoration along the lower River Rhine. PhD Thesis, Wageningen University, 205 pp.

Grift RE, Buijse AD, van Densen WLT, Machiels MAM, Kranenbarg J, Klein Breteler GP, Backx JJGM. 2003. Suitable habitats for 0-group fish in rehabilitated floodplains along the lower River Rhine. River Res Appl 19(4):353-374. doi:10.1002/rra.711

Guinan ME Jr, Kapuscinski KL, Teece MA. 2015. Seasonal diet shifts and trophic position of an invasive cyprinid, the rudd Scardinius erythrophthalmus (Linnaeus, 1758), in the upper Niagara River. Aquat Invasions 10(2):217-225. doi:10.3391/ai.2015.10.2.10

Gundrizer AN. 1958. Biology and fishing of ide in the western Siberia. In: Pravdin IF and Pirozhnikov PL (eds.) Commercial fishes of Ob and Enisey and their use. Izv. VNIORH 44. Moscow, Pishchepromizdat, pp. 49-60.

Haberman H, Kangur M, Kirsipuu A, Luts A, Mikelsaar N, Pihu E, Pihu E, Tell H. 1973. Kalad ja kalandus. [Fish and fisheries] In: Timm T (ed.) Võrtsjärv. Valgus, Tallinn, pp 144-194. [In Estonian.]

Haenen OLM, Davidse A. 1993. Comparative pathogenicity of two strains of pike fry rhabdovirus and spring viremia of carp virus for young roach, common carp, grass carp and rainbow trout. Dis Aquat Organ 15(2):87-92. doi:10.3354/dao015087 
Hanel L. 1984. Notes on the age and growth of the chub (Leuciscus cephalus), dace (L. leuciscus) and orfe (L. idus) (Pisces, Cyprinidae) in the rivulet Bystřice (northeastern Bohemia). Věst čs Společ zool 48:81-89.

Hanel L, Plesník J, Andreska J, Lusk S, Novák J, Plíštil J. 2011. Alien fishes in European waters. Zo Čsop Vlašim Bulletin Lampetra 7:148-185.

Hao CL, Yue C, Yao WJ, Yin JG, Jiao L, Zhu MY, Wang X. 2014. Population dynamics of Dactylogyrus in Leuciscus idus Linnaeus in Irtysh River of China. Acta Hydrobiol Sin 38(2):227-232. doi:10.7541/2013.34

Harzevili AS, Vught I, Auwerx J, De Charleroy D. 2012. Larval rearing of ide (Leuciscus idus (L.)) using decapsulated Artemia. Arch Polish Fish 20(3):219-222. doi:10.2478/v10086$012-0028-9$

Heggenes J. 1983. Fiskeribiologikse undersøkelser i Landefoss, Numedalslågen [Fisheries biological surveys in Landefoss, Numedalslågen]. Rapp. Lab. Ferskv. Økol. Innlandsfiske, 57, Oslo, $31 \mathrm{pp}$.

Hensel K. 2015. Prehl'ad údajov o vel'kosti, veku a raste rýb vo vodách Slovenska. [Overview of data on the size, age and growth of fish in Slovak waters]. Rybomil - časopis Slovenskej ichtyologickej spoločnosti 2:12-91. [In Slovak.]

Hickley P, Chare S. 2004. Fisheries for non-native species in England: angling or the environment? Fish Manag Ecol 11(3-4):203-212. doi:10.1111/j.1365-2400.2004.00395.x

Hill JE. 2009. Risk analysis for non-native species in aquaculture. SRAC Publication 4304. U.S. Department of Agriculture, Southern Regional Aquaculture Center. Stoneville, Mississippi. http://fisheries.tamu.edu/files/2013/09/SRAC-Publication-No.-4304-RiskAnalysis-for-Non-Native-Species-in-Aquaculture.pdf 
Hochman L. 1956. Zkušenosti s chovem jesenů v rybnících [Experiments with breeding ide in ponds]. Unknown, p. 69.

Holčík J. 1984. Review of experiments with introduction and acclimatization of the huchen, Hucho hucho (Linnaeus, 1758) (Salmonidae). In: European Inland Fisheries Advisory Commission. Documents presented at the symposium on stock enhancement in the management of freshwater fisheries, 2. EIFAC Technical Paper 42, pp 290-298.

Holčík J. 1991. Fish introductions in Europe with particular reference to its central and eastern part. Can J Fish Aquat Sci 48(S1):13-23. doi:10.1139/f91-300

Howeth JG, Gantz CA, Angermeier PL, Frimpong EA, Hoff MH, Keller RP, Mandrak NE, Marchetti MP, Olden JD, Romagosa CM, Lodge DM. 2016. Predicting invasiveness of species in trade: climate match, trophic guild and fecundity influence establishment and impact of non-native freshwater fishes. Divers Distrib 22(2):148-160. doi:10.1111/ddi.12391

Huitfeldt-Kaas H. 1917. Mjøsens fisker og fiskerier [Mjøsen's fishermen and fisheries]. K norske vidensk Selsk Skr 2:1-257 [In Norwegian.]

Humair F, Edwards PJ, Siegrist M, Kueffer C. 2014. Understanding misunderstandings in invasion science: why experts don't agree on common concepts and risk assessments. NeoBiota 20:1-30. doi:10.3897/neobiota.20.6043

Huo TB, Yuan MY, Jiang ZF. 2011. Length-weight relationships of 23 fish species from the Ergis River in Xingjiang, China. J Appl Ichthyol 27(3):937-938. doi:10.1111/j.14390426.2010.01528.x

Izyumova NA. 1987. Parasitic fauna of reservoir fishes of the URSS and its evolution. Amerind Publishing CO. Pvt. Ltd, New Dehli, India. 
Jääskeläinen V. 1917. Om fiskarna och fisket i Ladoga [About the fishermen and fishing in Ladoga]. Finlands Fiskerier 4:250-332 [In Swedish.]

Jääskeläinen. 1921. Über die Nahrung und die Parasiten der Fische im Ladogasee. Ann Acad Sci Fenn (Serie A) 14:1-55. [In German.]

Jakubowski H, Penczak T. 1970. Materiały do znajomości wzrostu ryb rodzaju Leuciscus Agass. w rzekach Wyżyny Łódzkiej i terenów przyległych [Materials to the knowledge of the growth of Leuciscus Agass. species in the rivers of Łódź upland and adjacent areas]. Zeszyty Naukowe Uniwersytetu Łódzkiego Nauki Matematyczno-Przyrodnicze, Seria II, 40:83-92. [In Polish.]

Järvalt A. 1981. Säina morfomeetriast ja kasvust mõnedes Eesti NSV veekogudes.[On ide morphometry and growth in some water bodies of the Estonian SSR]. Thesis Dissertation, Institute of Zoology and Hydrobiology, University of Tartu, 67 pp. [In Estonian.]

Järvalt A, Palm A, Turovski A. 2003. Ide, Leuciscus idus (L.) In: Ojaveer E, Pihu E, Saat T, editors. Fishes of Estonia. Estonian Academy Publishers, Tallinn. pp 179-183.

Jelkić D, Opaĉak A, Ozimec S, Florijanĉić T, Puškadija Z, Boškovići I. 2010. Monitoring the ichthyofauna in nature park Kopački Rit (Croatia) in 2008. $38^{\text {th }}$ IAD Conference, June 2010, Dresden, Germany, pp. 1-5.

Jereščenko VI. 1959. K biologii promsylovych ryb ozer severnogo Kazachstana [On the biology of commercial fish in lakes in northern Kazakhstan]. Sbornik Rabot po Ichtiologii i Gibrobiologii 2:208-233. [In Russian.]

Jeżewski W, Kamara A. 1999. First reported occurrence of Thelohanellus oculileucisci (Trojan, 1909) (Myxosporidia) in Leuciscus leuciscus (L.) and L. idus (L.) in Poland. Acta Parasitol 44(2):145-146 
Johnson T. 1982. Seasonal migrations of anadromous fishes in a northern Swedish coastal stream. In: Müller K (ed) Coastal research in the Gulf of Bothnia. Dr W. Junk Publishers, The Hague, pp 353-362.

Kangur M. 1963. Säinast Nasva jões. [About ide in the River Nasva]. Thesis dissertation, University of Tartu, Estonia. [In Estonian.]

Katzenberg MA, Weber A. 1999. Stable isotope ecology and palaeodiet in the Lake Baikal region of Siberia. J Archaeol Sci 26(6):651-659. doi:10.1006/jasc.1998.0382

Keith P, Allardi J. 2001. Atlas des poissons d'eau douce de France. Muséum National d'Histoire Naturelle, Paris, 387 pp. [In French.]

Keith P, Persat H, Feunteun É, Allardi J. 2011. Les poissons d'eau douce de France. Muséum National d'Histoire Naturelle, Paris. [In French.]

Kennedy CR. 1975. The distribution of some crustacean fish parasites in Britain in relation to the introduction and movement of freshwater fish. Aquacult Res 6(2):36-41. doi:10.1111/j.1365-2109.1975.tb00155.x

Kirjušina M, Vismanis K. 2007. Checklist of the parasites of fishes of Latvia. FAO Fisheries Technical Paper. No. 369/3. Rome, FAO. 106 pp.

Klein Breteler JGP, de Laak GAJ (2003) Lengte-gewichtrelaties Nederlandse vissoorten [Length-weight relationships of Dutch fish species]. Deelrapport I, versie 2. Organisatie ter Verbetering van de Binnenvisserij, Nieuwegein. OVB-rapportnummer OND00074, 13 pp. [In Dutch.]

Kleszcz S. 2008. Tempo wzrostu wybranych gatunków ryb występujacych w zbiorniku Mietkowskim [Growth rate of some fish species occurring in Mietków reservoir]. MSc Thesis, Wrocław University of Environmental and Life Sciences, The Faculty of Biology and Animal Science, Wrocław, $55 \mathrm{pp}$. 
Koblickaya AF. 1981. Identification keys for young of freshwater fishes. Consumer and Food Industry Press, Moscow. [In Russian.]

Koli L. 1990. Suomen kalat [Fishes of Finland]. Werner Söderström Osakeyhtiö, Helsinki. [In Finnish.]

Koopmans JH, van Emmerik WAM. 2006. Leuciscus idus L. Sportvisserij Nederland, Bilthoven. Kennisdocument 20: 52 p. [In Dutch.]

Kopiejewska W, Terlecki J, Chybowski Ł. 2003. Varied somatic growth and sex cell development in reciprocal hybrids of roach Rutilus rutilus (L.) and ide Leuciscis idus (L.). Arch Polish Fish 11(1):33-44.

Kortan J, Adamek Z, Flajshans M, Piackova V. 2008. Indirect manifestations of cormorant (Phalacrocorax carbo sinensis (L.)) predation on pond fish stock. Knowl Manag Aquat Ecosyst 389, article 1. doi:10.1051/kmae:2008006

Kottek M, Grieser J, Beck C, Rudolf B, Rubel F. 2006. World map of the Ko"ppen-Geiger climate classification updated. Meteorol Z 15(3):259-263. doi:10.1127/0941$2948 / 2006 / 0130$

Kovrižnych J, Holčík J, Krupka I. 1986. Správa o ichtyologickom prieskumu [sic!] nádrže Králová nad Váhom a návrh na jej rybárske obhospodarovanie [Report on the ichthyological survey [sic!] Of the Králová nad Váhom reservoir and a proposal for its fisheries management]. Záverečná správa, Laboratórium rybárstva a hydrobiológie, Bratislava, 16 pp. [In Slovak.]

Krejszeff S, Targońska K, Zarski D, Kucharczyk D. 2009. Domestication affects spawning of the ide (Leuciscus idus) - preliminary study. Aquaculture 295(1-2):145-147. doi:10.1016/j.aquaculture.2009.06.032 
Krištofík E. 1961. Jalec tmavý (Leuciscus idus L.) v povodí rieky Nitry (rozšírenie, biometrika, rast, plodnost' a hospodársky význam) [Black hake (Leuciscus idus L.) in the Nitra river basin (distribution, biometrics, growth, fertility and economic importance)]. Diplomová práca, Vysoká škola pol'nohospodárska, Nitra, 85 pp. [In Slovak.]

Kruk A. 2007. Role of habitat degradation in determining fish distribution and abundance along the lowland Warta River, Poland. J Appl Ichthyol 23(1):9-18. doi:10.1111/j.14390426.2006.00784.x

Kruk A, Ciepłucha M, Zięba G, Błońska D, Tybulczuk S, Tszydel M, Marszał L, Janic B, Pietraszewski D, Przybylski M, Penczak T. 2017. Spatially diverse recovery (1986-2012) of fish fauna in the Warta River, Poland: The role of recolonizers' availability after largearea degradation. Ecol Eng 101:612-624. doi:10.1016/j.ecoleng.2017.01.019

Krupka I. 1972. Populačné parametre a produkcia ichtyocenóz dvoch podunajských jazierok [Population parameters and production of ichthyocenoses of two Danube lakes]. Záverečná správa. Ústav rybárstva ahydrobiológie, Bratislava, 63 pp. [In Slovak.]

Kucharczyk D, Targoñska K, Zarski D, Kujawa R, Mamcarz A. 2008 A review of the reproduction biotechnology for fish from the genus Leuciscus. Arch Polish Fish 16(4):319340. doi:10.2478/s10086-008-0021-5

Kulíšková P, Horký P, Slavík O, Jones JI. 2009. Factors influencing movement behaviour and home range size in ide Leuciscus idus. J Fish Biol 74(6):1269-1279. doi:10.1111/j.10958649.2009.02198.x

Kupren K, Mamcarz AA, Kucharczyk DD. 2010. Effects of temperature on survival, deformations rate and selected parameters of newly hatched larvae of three rheophilic cyprinids (genus Leuciscus). Pol J Natur Sc 25(3): 299-312. doi:10.2478/v10020-010-00275 
Kupren K, Żarski D, Kucharczyk, D. 2015. Early development and allometric growth patterns in ide Leuciscus idus (Linnaeus 1758). J Appl Ichthyol 31(3):509-517. doi:10.1111/jai.12747

de Leeuw JJ, Winter HV. 2006. Telemetriestudie naar migratiebarrières voor riviervis (winde, barbeel, kopvoorn, sneep). [Telemetry study on river fish migration barriers (ide, barbel, chub, nase)]. IMARES Rapportnummer: C074/06, 23 pp. [In Dutch.]

de Leeuw JJ, Winter HV. 2008. Migration of rheophilic fish in the large lowland rivers Meuse and Rhine, the Netherlands. Fish Manag and Ecol 15(5-6):409-415. doi:10.1111/j.13652400.2008.00626.x

de Leeuw JJ, Buijse AD, Grift RE, Winter HV. 2005. Management and monitoring of the return of riverine fish species following rehabilitation of Dutch rivers. Arch Hydrobiol (Suppl.) 155(1-4):391-411.

Lefler KK, Hegyi Á, Baska F, Gál J, Horváth Á, Urbányi B, Szabó T. 2008. Comparison of ovarian cycles of Hungarian riverine fish species representing different spawning strategies. Czech J Anim Sci 53(10):441-452. http://real.mtak.hu/id/eprint/5220

Lelek A, Libosvárský J. 1960. Occurrence of fish in a fish ladder in the Dyje River near Breclav. Folia Zoologica 14:293-308. [In Czech.]

Lehtonen H. 1996. Potential effects of global warming on northern European freshwater fish and fisheries. Fish Manag Ecol 3(1):59-71. doi:j.1365-2400.1996.tb00130.x

Leunda PM. 2010. Impacts of non-native fishes on Iberian freshwater ichthyofauna: current knowledge and gaps. Aquat Invasions 5(3):239-262. doi:10.3391/ai.2010.5.3.03

Leuven RSEW, Hendriks AJ, Huijbregts MAJ, Lenders HJR, Matthews J, van der Velde G. 2011. Differences in sensitivity of native and exotic fish species to changes in river temperature. Current Zool 57(6):852-862. doi:10.1093/czoolo/57.6.852 
Lever C. 1977. The naturalised animals of the British Isles. Hutchinson \& Co Limited, London.

Liberman E. 2020. Trematodes of cyprinid fish of the Lower Irtysh. IOP Conf Ser.: Earth Environ Sci 539, article 012196. doi:10.1088/1755-1315/539/1/012196

Liberman EL, Chemagin AA. 2017. Selected morphometric and biological characteristics of ide Leuciscus idus (Linnaeus, 1758) in the lower Irtysh. Astrakhan State Technical University, Fisheries Series 1:46-53. [In Russian.]

Lujić J, Kostić, D, Bjelić-Čabrilo O, Popović E, Miljanović B, Marinović Z, Marković G. 2013. Ichthyofauna Composition and Population Parameters of Fish Species from the Special Nature Reserve "Koviljsko-Petrovaradinski Rit" (Vojvodina, Serbia) Turk J Fish Aquat Sci 13:665-673. doi:10.4194/1303-2712-v13_4_12

Lukin AV. 1934. Some data on the biology of commercial fish of the Volga River basin in TASSR, Uch. Zap. Kazan. Univ., Vol. 94, book 4, no. 2, pp 174-189 [In Russian.]

Lukin AV, Shteynfel'd AL. 1949. Plodovitost' glavneyshikh promyslovykh ryb Sredney Volgi [Fecundity of main commercial fishes of the Middle Volga]. Proceedings of the Kazan branch of the USSR Academy of Sciences. Biological and agricultural series, 1:87-106. [In Russian.]

Maceda-Veiga A, Escribano-Alacid J, de Sostoa A, García-Berthou E. 2013. The aquarium trade as a potential source of fish introductions in southwestern Europe. Biol Invasions 15(12):2707-2716. doi:10.1007/s10530-013-0485-0

Mandrak NE, Gantz C, Jones LA, Marson D, Cudmore B. 2014. Evaluation of five freshwater fish screening-level risk assessment protocols and application to non-indigenous organisms in trade in Canada. Department of Fisheries and Oceans, Canadian Science Advisory Secretariat Research Document 2013/122, v + 125 pp. 
Maitland PS. 1972. A key to the freshwater fishes of the British Isles with notes on their distribution and ecology. Scientific Publication No. 27. Ambleside: Freshwater Biological Association, $139 \mathrm{pp}$.

Maitland, PS, Campbell RN. 1992. Freshwater fishes of the British Isles. HarperCollins Publishers, London, 368 pp.

Mann RHK. 1996. Environmental requirements of European non-salmonid fish in rivers. Hydrobiologia 323:223-235. doi:10.1007/BF00007848

Martinson A. 1980. Bentofaagsete kalade toitumisest Kasari ja tema lisajõgedes. [On the diet of benthophagous fish in Kasari and its tributaries] Thesis Dissertation, Tartu State University [In Estonian.]

McAllister PE, Lidgerding BC, Herman RL, Hoyer LC, Hankins J. 1985. Viral diseases of fish: first report of carp pox in golden ide (Leuciscus idus) in North America. J Wildlife Dis 21(3):199-204. doi:10.7589/0090-3558-21.3.199

McDowall RM. 2000. The Reed field guide to New Zealand freshwater fishes. Reed Books, Auckland, New Zealand.

Menshikov MI, Bukiriev AI. 1934. Ryby i rybolovstvo verchoviev reki Kamy. [Upper Kama River Fish and Fisheries]. Trudy Biologicheskogo Nauchno-Issledovatel'skogo Instituta Permskogo Universitet 6 (1-12):1-99 [In Russian.]

Mercado-Silva N, Gilroy DJ, Erdenebat M, Hogan Z, Chandra S, Vander Zanden MJ (2008) Fish community composition and habitat use in the Eg-Uur River system, Mongolia. Mongolian Journal of Biological Sciences 6(1-2):21-30. https://www.biotaxa.org/mjbs/article/download/26872/24796

Mickiewicz M, Wołos A. 2020. Gospodarka rybacka w śródlądowych wodach płynących w 2018 r. Cz. 2. Charakterystyka zarybień [Fisheries management in inland waters flowing in 
2015. Part 2. Characteristic of the stocking]. Komunikaty Rybackie 2(175):6-11. [In Polish.]

Molnar K. 1969. Beiträge zur Kenntnis der Fischparasitengauna Ungarns IV. Trematoden. Parasitol Hung 2:119-136. [In German.]

Moravec F. 1994. Parasitic Nematodes of Freshwater Fishes of Europe. Academic, Prague and Kluwer Academic Publishers, Dortrecht, 473 pp.

Moravec F. 2001. Checklist of the Metazoan Parasites of Fishes of the Czech Republic and the Slovak Republic (1873-2000). Academia, Praha, 168 pp.

Muromova GV. 1930. Vozrast i tempy rosta jazia (Leuciscus idus L.) reki Vack [Age and growth rate of ide (Leuciscus idus L.) of the River Vask]. Trudy Sib Rybochoz St 5:125151. [In Russian.]

Mutenia A. 1978. On the biology of the ide (Leuciscus idus L.) in Lokka reservoir, Finnish Lapland. Luonnon Tutkija, 82:135-137 [In Finnish.]

Mühlen von zur M., Schneider G. 1920. Der Zee Wirzjerw in Livland. Archiv für die Naturkunde des Ostbaltikums, 14, 158 pp.

Müller K. 1982. Coastal research in the Gulf of Bothnia. Dr W. Junk Publishers, The Hague.

Müller K, Berg E. 1982. Spring migration of some anadromous freshwater fish species in the northern Bothnian Sea. Hydrobiologia 96:161-168. doi:10.1007/BF02185431

Naiksatam A. 1976. Population dynamics of Abramis brama (L.), Abramis bjoerkna (L.) and Leuciscus idus (L.) in the arm Žofín (inundation region of Danube). Acta Universitatis Carolinae - Biologica (Praha) 1973:235-292. 
Neja Z. 2011. Charakterystyka ichtiofauny i rybactwa w wodach Międzyodrza [Charakterystyka ichtiofauny i rybactwa w wodach Międzyodrza]. ZUT, Szczecin. [In Polish.]

Nermer T, Grochowski A, Fey D, Radtke K, Szymanek L, Ramutkowski M, Lejk A, Psuty I, Horbowa K, Celmer Z, Dziemian Ł, Zaporowski R, Jarek T, Witalis B, Wodzinowski T. 2012. Wyniki realizacji III etapu projektu "Inwentaryzacja ichtiofauny w polskiej części Zalewu Wiślanego wraz z Zatoką Elbląską" [Results of the 3rd stage of the project "Inventory of ichthyofauna in the Polish part of the Vistula Lagoon along with the Elbląg Bay"]. Raport MIR-PIB na Zlecenie UM w Gdyni [MIR-PIB report to the Medical University of Gdynia], 177 pp. [In Polish.]

Nevický O. 1992. Vek a rast introdukovaných kaprovitých rýb Štrbského plesa - plotice obyčajnej (Rutilus rutilus) a xantorického jalca tmavého (Leuciscus idus aberr. orfus) [Age and growth of introduced carp fish Štrbské pleso - common roach (Rutilus rutilus) and xantoric ide (Leuciscus idus aberr. orfus)]. Pol'nohospodárstvo (Bratislava) 38:202-212. [In Slovak.]

Nico L, Fuller P, Neilson M, Fusaro A, Davidson A, Alame K, Gappy M, Conard W. 2020. Leuciscus idus (Linnaeus, 1758). U.S. Geological Survey, Nonindigenous Aquatic Species Database, Gainesville, FL, and NOAA Great Lakes Aquatic Nonindigenous Species Information System, Ann Arbor, MI. https://nas.er.usgs.gov/queries/greatlakes/FactSheet.aspx?SpeciesID=62\&Potential=Y\&Ty $\mathrm{pe}=2 \& H U C N u m b e r=$

Nicolaisen O. 1996. Natural selection and subsequent evolution in a population of golden ide (Leuciscus idus) following the introduction of three-spined sticklebacks (Gasterosteus aculeatus). MSc Thesis, University of Bergen. 
Niewiadomska K. 2003. Pasożyty ryb Polski. Przywry Digenea. [Polish fish parasites. Flukes - Digenea]. Polskie Towarzystwo Parazytologiczne, Warszawa.

Nikolsky GV, Gromchevskaya NA, Morozova GI, Pikuleva VA. 1947. Ryby bassejna verchnej Pechory [Fishes of the Upper Pechora basin]. Izd. MOIP, Moskva, pp. 1-102. [In Russian.]

Ogle DH. 2016. Introductory fisheries analyses with R. CRC Press, Boca Raton, FL, 486 pp.

Ondračková M, Matějusová I, Šimková A, Gelnar M. 2004. New reports of dactylogyridean species (Monogenea) for Central Europe. Helminthologia 41(2):139-145.

O'Maoileidigh N, Bracken JJ. 1989. Biology of the tench Tinca tinca L. in an Irish lake. Aquacul Fish Manag 20(2):199-210. doi:10.1111/j.1365-2109.1989.tb00345.x

Oolu A. 1970. Säinas Eesti lääneranniku meres. [Ide in the sea on the west coast of Estonia] Eesti Loodus 12:748-750. [In Estonian.]

Otterstrøm CV. 1930. De Danske Skallearter (Leuciscus rutilus L., Leuciscus grislagine L., Leuciscus idus L. og Leuciscus erythrophthalmus L.) [The Danish Leuciscus species (Leuciscus rutilus L., Lenciscus grislagine L., Leuciscus idus L. and Leuciscus erythrophthalmus L.)]. Videnskabelige Meddelelser Dansk Naturhistorisk Forening 90:85311. [In Danish.]

Palm HW, Klimpel S, Bucher, C. 1999. Checklist of metazoan fish parasites of German coastal waters. Berichte aus dem Institute für Meereskunde an der Christian-Albrechts-Universität Kiel, No. 307, 148 pp.

Pascal M, Lorvelec O, Vigne J-D, Keith P, Clergeau P. (Eds). 2003. Évolution holocène de la faune de vertébrés de France: invasions et disparitions. Institut National de la Recherche Agronomique, Centre National de la Recherche Scientifique, Muséum National d'Histoire Naturelle. Rapport au Ministère de l'Écologie et du Développement Durable (Direction de la Nature et des Paysages), Paris, France. Version définitive du 10 juillet 2003, pp 381. 
Pavlov DS. 1994. The downsteam migration of young fishes in rivers: mechanisms and distribution. Folia Zool 43(3):193-208.

Peel MC, Finlayson BL, McMahon TA. 2007. Updated world map of the Köppen-Geiger climate classification. Hydrology and Earth System Sciences Discussions 4(2):439-473. https://hal.archives-ouvertes.fr/hal-00298818/document.

Peňáz M. 1961. Poznámky k růstu jelce jesena v řece dyji [Notes on the growth of dice in the river Dyje]. Folia Zool 24(3):231-241. [In Czech.]

Peňáz M, Jurajda P. 1996. Endangered fishes of the River Morava (Czech Republic) In: Kirchhofer A, Hefti D (eds) Conservation of Endangered Freshwater Fish in Europe. Birkhauser Verlag, Basel, Switzerland, pp. 99-110.

Penczak T, Koszalinska M. 1993. Populations of dominant fish species in the Narew River under human impacts. Pol Arch Hydrobiol 40(1):59-75.

Penczak T, Głowacki Ł, Kruk A. 2017. Fish recolonization of a lowland river with nonbuffered storm water discharges but with abated pollution from a large municipality. Ecol Indic 73:398-410. doi:10.1016/j.ecolind.2016.09.054

Petlina AP, Romanov VI. 2004. Study of juvenile freshwater fish of Siberia. Tomsk Gos Univ, Tomsk, 203 pp. [In Russian.]

Pihu E. 1960. Võrtsjärve haugi, särje, latika, säina ja ahvena viljakusest [On the fertility of pike, roach, bream, ide and perch in Lake Võrtsjärv]. Loodusuurijate Seltsi aastaraamat 52:155-170. [In Estonian.]

Platonova OP. 1958. Ide of the Lower Kama and Middle Volga rivers. Uch Zap Kazan Univ: 118:257-318. [In Russian.] 
Pliszka F. 1953. The effect of spawning conditions in lakes on young fish populations. Pol Arch Hydrobiol 1:165-188.

Podlesnyi AV. 1958. Fishes of Enisey, their environments and use. In: Pravdin IF and Pirozhnikov PL (eds.) Commercial fishes of Ob and Enisey and their use. Izv. VNIORH 44. Moscow, Pishchepromizdat, pp. 97-178 [In Russian.]

Pojmańska T. 1991. Pasożyty ryb Polski. Tasiemce - Cestoda. [Fish parasites Polish. Tapeworms - Cestoda]. Instytut Parazytologii PAN, Warszawa.

Popescu E, Ziemiankowski V, Rotaru, A. 1960. Citeva observatii asupra fecundatiei artificiale si dezvoltarii embrionare si postembrionare la vaduvita (Leuciscus idus (L)). [Some observations on artificial insemination and embryonic and post-embryonic development in ide (Leuciscus idus (L))]. Bul Inst Cerc Pisc 17:57-64. [In Romanian.]

Popiołek M. 2016. Pasożyty ryb Polski. Kolcogłowy - Acanthocephala. [Polish fish parasites. Spike-head - Acanthocephala]. Polskie Towarzystwo Parazytologiczne, Warszawa.

Popov PA, Voskoboinikov VA, Shchenev VA. 2005. Fishes of Lake Chany. Sib Ekol Zh 2:279-293. [In Russian.]

Povž M. 1996. The Red Data List of the freshwater lampreys (Cyclostomata) and fish (Pisces) of Slovenia In: Kirchhofer A, Hefti D (eds) Conservation of Endangered Freshwater Fish in Europe. Birkhäuser Verlag, Basel, Switzerland, pp. 63-72.

Probatov AN. 1929. Materials on the age of fish of the Pskov reservoir. Izv Otd Prik1 Ichtiologii 9:68-89. [In Russian.]

Pugachev ON, Gerasev PI, Gussev AV, Ergens R, Khotenowsky I. 2010. Guide to Monogenoidea of freshwater fish of Palaearctic and Amur regions. LedizioniLedipublishing, pp. 562. 
R Development Core Team. 2020. R: a language and environment for statistical computing. R Foundation for Statistical Computing, Vienna, Austria. www.R-project.org/

Rask M. 1989. A note on the diet of roach, Rutilus rutilus L., and other cyprinids at Tvärminne, northern Baltic Sea. Aqua Fennica 19:19-27.

Rautskis E. 1988. Parazity ryb vodoemov Litvy [Fish parasites in Lithuanian water bodies]. Mokslas, Vilnius, Lithania, pp. 209 [In Russian.]

Repečka R, Ložys L, Žiliukas V, Levickienė D, Jasiukonyte L, Rimkus R. 2012. Study of sustainable use of Curonian lagoon fish stocks. Nature Research Centre. 64 pp. [In Lithuanian.]

Ricker WE. 1975. Computation and interpretation of biological statistics of fish population. Bulletin (Fisheries Research Board of Canada), 191. Department of the Environment, Fisheries and Marine Service, Ottawa, $382 \mathrm{pp}$.

Ristkok J. 1970. Andmeid soomuskatte kujunemise algusest mõnedel mageveekaladel [Data on the onset of scale formation in some freshwater fish]. Acta et Commentationes Universitatis Tartuensis 255:49-60. [In Estonian.]

Ristkok J 1974. Andmeid kalade kasvust ja kasvukarakteristikast Eestis [Data on the growth and growth characteristics of fish in Estonia]. Acta et Commentationes Universitatis Tartuensis 333:3-91. [In Estonian.]

Rohtla M, Svirgsden R, Taal I, Saks L, Eschbaum R, Vetemaa M. 2015a. Life-history characteristics of ide Leuciscus idus in the Eastern Baltic Sea. Fish Manag Ecol 22(3):239248. doi:10.1111/fme. 12120

Rohtla M, Taal I, Svirgsden R, Vetemaa M. 2015b. Old timers from the Baltic Sea: Revisiting the population structure and maximum recorded age of ide Leuciscus idus. Fish Res 165:7478. doi:10.1016/j.fishres.2015.01.001 
Rokicki J. 2004. Parasymphylodora parasquamosa Kulakova, 1972 (Trematoda, Digenea) new species of the parasite fauna of Poland. Wiadomošci Parazytologiczne 50(1):29-30.

Rolbiecki L. 2003. Diversity of the parasite fauna of cyprinid (Cyprinidae) and percid (Percidae) fishes in the Vistula Lagoon, Poland. Wiadomošci Parazytologiczne 49(2):125164.

Rusinek OT. 2007. Fish parasites of Lake Baikal (fauna, communities, zoogeography and historical background). KMK Scientific Press Ltd., Moscow [In Russian.]

Sanft EJ. 2015. Prey preference for Asian carp and soft plastic lure ingestion by Largemouth Bass. MSc Thesis, University of Illinois, Urbana, Illinois.

Sayfullin RR, Shakirova FM. 2014. Age structure and linear growth rate of the population of ide Leuciscus idus (Linnaeus, 1788) in the Kuibyshev Reservoir in 2004-2005. Inlnd Water Biology 7(4)4:381-384.

Scheffel HJ, Schirmer M. 1991. Larvae and juveniles of freshwater and euryhaline fishes in the tidal River Weser at Bremen, FRG. Verh Internat Verein Limnol 24:2446-2450. doi:10.1080/03680770.1989.11899985

Schiemer F, Guti G, Keckeis H, Staras M. 2004. Ecological status and problems of the Danube River and its fish fauna: a review. In: Welcomme RL, Petr T (eds) Proceedings of the Second International Symposium on the Management of Large Rivers for Fisheries, Vol. I. Bangkok, Thailand: FAO Regional Office for Asia and the Pacific, pp. 273-300.

Schiphouwer ME, van Kessel N, Matthews J, Leuven RSEW, van de Koppel S, Kranenbarg J, Haenen OLM, Lenders HJR, Nagelkerke LAJ, van der Velde G, Crombaghs BHJM, Zollinger R. 2014. Risk analysis of exotic fish species included in the Dutch Fisheries Act and their hybrids. Nederlands Expertise Centrum Exoten (NEC-E), Nijmegen. http://hdl.handle.net/2066/123477 
Scholten M, Wirtz C, Fladung E, Thiel R. 2003. The modular habitat model (MHM) for the ide, Leuciscus idus (L.) - a new method to predict the suitability of inshore habitats for fish. J Appl Ichthyol 19(5):315-329. doi:10.1046/j.1439-0426.2003.00507.x

Schuijf A, Visser C, Willers AFM, Buwalda RJA. 1977. Acoustic localization in an ostariophysian fish. Experientia 33:1062-1063.

Schwartz FJ. 1972. World literature to fish hybrids with an analysis by family, species, and hybrid. Publications of the Gulf Coast Research Laboratory Museum, No. 3, 328 pp.

Schwartz FJ. 1981. World literature to fish hybrids with an analysis by family, species, and hybrid: Supplement 1. Seattle, Wash: National Oceanic and Atmospheric Administration, $507 \mathrm{pp}$.

Sedlár J. 1966. Príspevok k poznaniu veku a rastu jalca tmavého (Leuciscus idus L.) v Žitave [Contribution to the knowledge of the age and growth of the black heifer (Leuciscus idus L.) in Zittau]. Acta zootechnica Universitatis agriculturae (Nitra) 14:127-189 [In Slovak.]

Sedlár J. 1989. Charakteristika našich rýb [Characteristics of our fish]. In: Sedlár et al. - Atlas rýb. Obzor, Bratislava, pp. 80-301. [In Slovak.]

Sedlár J, Stráňai I, Makara, A. 1985. Súčasný stav zarybnenia povodia Hrona. V. Vek a lineárny rast produkčne rozhodujúcich druhov rýb povodia Hrona [Current state of restoration of the Hron basin. V. Age and linear growth of production-decisive fish species in the Hron basin.]. Pol'nohospodárstvo (Bratislava) 31: 133-144 [In Slovak.]

Segerstråle C. 1933. Über scalimetrische Methoden zur Bestimmung des Linearen Wachstum bei Fischen, insbesondere bei Leuciscus idus L., Abramis brama L. und Perca fluviatilis L. Acta Zoologica Fennica 15:1-168. [In German.]

Serov NP. 1959. Ichthyofauna Kamysh - Samarsky and Kushumsky lakes. Sbornik rabot po Ichtiologii i Gidrobiologii 2:152-175. [In Belarussian]. 
Shcherbina G Kh, Buckler DR. 2006. Distribution and ecology of Dreissena polymorpha (Pallas) and Dreissena bugensis (Andrusov) in the Upper Volga Basin. ASTM International 3(4):1-11. doi:10.1520/JAI13256

Sidorova AF. 1959. Jaz vodojemov - Irgiz-Turgay [Ide of water bodies of Irgyz-Turgay]. Alma-Ata (Almaty), Sbornik rabot po ichtiologii i gidrobiologii, 2:191-207 [In Russian.]

Simonsen JH. 2000. Gullvederbuk i Ånavassdraget, Kristiansand og Lillesand kommuner. [Golden orfe in the Ånavassdraget, Kristiansand and Lillesand municipalities]. Notat, 16 pp.

Šindléryová V. 1965. Príspevok k štúdiu veku a rastu jalca tmavého (Leuciscus idus) v kanáli Asód [Contribution to the study of age and growth of Leuciscus idus in the Asód Canal]. Diplomová práca, Vysoká škola pol’nohospodárska, Nitra, 57 pp. [In Slovak.]

Siriwardena S. 2008. Leuciscus idus (Ide). Data Sheet. Invasive Species Compendium. www.cabi.org/isc/datasheet/77315

Skovrind M, Olsen MT, Vieira FG, Pacheco G, Carl H, Gilbert MTP, Møller PR. 2016. Genomic population structure of freshwater-resident and anadromous ide (Leuciscus idus) in north-western Europe. Ecol Evol 6(4):1064-1074. doi:10.1002/ece3.1909

Skóra KE. 1996. New and rare fish species from the Gulf of Gdansk. Zool Pol 41(Suppl.):113130 [In Polish.]

Skóra ME. 2015. Ichthyofauna species diversity in the river mouth stretch of the Reda River. PhD Thesis, University of Gdańsk, Gdynia, Poland. 152 pp. [In Polish.]

Smith RJF. 1991. Social behaviour, homing and migration. In: Winfield IJ, Nelson JS (eds.) Cyprinid Fishes: Systematics, Biology and Exploitation. Chapman \& Hall, London, pp 509529. 
Sobecka E, Jurkiewicz E, Piasecki W. 2004. Parasite fauna of ide, Leuciscus idus (L.) in Lake Dàbie, Poland. Acta Ichthyol Piscat 34(1):33-42.

Spikmans F, Kranenbarg J. 2016. Nieuwe Rode Lijst vissen Nederland: Lichte verbetering voor zoetwatervissen [New Red List for fishes in the Netherlands: Slight improvement for freshwater fish]. RAVON 18(1):9-12. [In Dutch with English abstract.]

Spillmann CJ. 1961. Poissons d'eau douce. Faune de France, Editions Paul Lechevalier, 75006, Paris, France, pp 303.

Ståhlberg S, Svanberg, I. 2011. Catching basking ide, Leuciscus idus (L.), in the Baltic Sea: fishing and local knowledge in the Finnish and Swedish Archipelagos. J North Stud 5(2):87104. http://urn.kb.se/resolve?urn=urn\%3Anbn\%3Ase\%3Aumu\%3Adiva-52757

Sterud E. 1999. Parasitter hos norske ferskvannsfisk. Norsk Zoologist Forening. [Parasites in Norwegian freshwater fish. Norwegian Zoologist Association]. Rapport, Oslo 7. [In Norwegian.]

Sterud E, Appleby C. 1997. Parasites of dace (Leuciscus leuciscus), ide (L. idus) and chub (L. cephalus) from south-eastern Norway. Bull Scand Soc Parasitol 7:19-24.

Sterud E, Poynton SL. 2002. Spironucleus vortens (Diplomonadida) in the ide, Leuciscus idus (L.) (Cyprinidae): a warm water hexamitid flagellate found in Northern Europe. J Eukaryot Microbiol 49(2):137-145. doi:10.1111/j.1550-7408.2002.tb00357.x

Svetovidova AF. 1949. Jaz [Ide] - Leuciscus idus (Linné). In: Promyslovyje ryby SSSR [Commercial fish of the USSR], pp. 343-345. [In Russian.]

Swenson JE. 1979. The relationship between prey species ecology and dive success of ospreys. The Auk 96(2):408-412. 
Tadajewska M. 2000. Jaź [Ide] In: Brylińska M, editor. Ryby słodkowodne Polski [Freshwater fish of Poland]. Warszawa, Poland, Wydawnictwa Naukowe PWN: p 314-318. [In Polish.]

Targońska K, Kupren K, Żarski D, Król R, Kucharczyk D. 2011. Influence of thermal conditions on successful ide (Leuciscus Idus L.) artificial reproduction during spawning season. Italian J Anim Sci 10(4):209-212. doi:10.4081/ijas.2011.e50

Targońska K, Zarski D, Krejszeff S, Kucharczyk D. 2012. Influence of age of wild ide Leuciscus idus (L.) female on spawning effectiveness under controlled conditions. Ital J Anim Sci 11(4):342-346. doi:10.4081/ijas.2012.e63

Thomas K, Ollevier F. 1992. Paratenic hosts of the swimbladder nematode Anguillicola crassus. Dis Aquat Organ 13:165-174.

Treer T, Šprem N, Torcu-Koc H, Sun Y, Piria M. 2008. Length-weight relationships of freshwater fishes of Croatia. J Appl Ichthyol 24(5):626-628. doi:10.1111/j.14390426.2008.01084.x

Treer T, Piria M, Šprem N. 2009. The relationship between condition and form factors of freshwater fishes of Croatia. J Appl Ichthyol 25(5):608-610. doi:10.1111/j.14390426.2009.01266.x

Tyurin PV. 1927. About the relation between the length of the fish and its weight. Rep. Icht. Lab. Siberia 2(3):3-21.

Tyutenkov SK. 1956. Nutrition and feeding relationships of fishes of Lake Kurgaldzhin. Collection of works on ichthyology and hydrobiology. Alma-Ata: Institut Zoologii AN KazSSR, pp 124-154. [In Russian.]

van Beek GCW. 1999. Literatuurstudie naar zouttolerantie en gerelateerde parameters van vissoorten in het benedenrivierengebied. [Literature study on salt tolerance and related parameters of fish species in the lower river area] Bureau Waardenburg bv. [In Dutch.] 
Vechkanov VS. 2000. Fishes of Mordovia. Mordovskiy University, Saransk. [In Russian.]

Veld CJ. 1969 Enkele aspecten van de biologie van de winde Leuciscus idus (Linnaeus, 1758). [Some aspects of the biology of the ide Leuciscus idus (Linnaeus, 1758)]. RIVO. [In Dutch.]

Veldkamp R. 1995. Diet of cormorants Phalacrocorax carbo sinensis at Wanneperveen, the Netherlands, with special reference to bream Abramis brama. Ardea 83:143-155.

Vetemaa M, Eschbaum R, Albert A, Saks L, Verliin A, Jürgens K, Kesler M, Hubel K, Hannesson R, Saat T. 2010. Changes in fish stocks in an Estonian estuary: overfishing by cormorants? ICES J Mar Sci 67(9):1972-1979. doi:10.1093/icesjms/fsq113

Verreycken H. 1998. Viskweekactiviteiten in de viskwekerijen van het Vlaams Gewest in 1997 [Fish farming activities in the fish farms of the Flemish Region in 1997]. INBO Report IBW.Wb.V.IR.98.070. [In Dutch.]

Verreycken H, Van Thuyne G, Belpaire C. 2011. Length-weight relationships of 40 freshwater fish species from two decades of monitoring in Flanders (Belgium). J Appl Ichthyol 27(6):1416-1421. doi:10.1111/j.1439-0426.2011.01815.x

Verreycken H, Belpaire C, Van Thuyne G, Breine J, Buysse D, Coeck J, Mouton A, Stevens M, Van Den Neucker T, De Bruyn L, Maes D. 2014. IUCN Red List of freshwater fishes and lampreys in Flanders (north Belgium). Fish Manag Ecol 21(2):122-132. doi:10.1111/fme.12052

Vilizzi L. 2012. The common carp, Cyprinus carpio, in the Mediterranean region: origin, distribution, economic benefits, impacts and management. Fish Manag Ecol 19(2), 93-110. doi:10.1111/j.1365-2400.2011.00823.x

Vilizzi L. 2018. Age determination in common carp Cyprinus carpio: history, relative value of structures, precision and accuracy. Rev Fish Biol Fisher 28:461-484. doi:10.1007/s11160018-9514-5 
Vilizzi L, Copp GH. 2017. Global patterns and clines in the growth of common carp Cyprinus carpio. J Fish Biol 91(1):3-40. doi:10.1111/jfb.13346

Vilizzi L, Tarkan AS, Copp GH. 2015. Experimental evidence from causal criteria analysis for the effects of common carp Cyprinus carpio on freshwater ecosystems: a global perspective. Rev Fish Sci Aquacul 23(3):253-290. doi:10.1080/23308249.2015.1051214

Vilizzi L, Copp GH, Adamovich B, Almeida D, Chan J, Davison PI, Dembski S, Ekmekçi FG, Ferincz Á, Forneck SC, Hill JE, Kim J-E, Koutsikos N, Leuven RSEW, Luna SA, Magalhães F, Marr SM, Mendoza R, Mourão CF, Neal JW, Onikura N, Perdikaris C, Piria M, Poulet N, Puntila R, Range IL, Simonović P, Ribeiro F, Tarkan AS, Troca DFA, Vardakas L, Verreycken H, Vintsek L, Weyl OLF, Yeo DCJ, Zeng Y. 2019. A global review and meta-analysis of applications of the freshwater Fish Invasiveness Screening Kit. Reviews in Fish Biology and Fisheries 29: 529-568. doi:10.1007/s11160-019-09562-2

Virbickas J. 2000. Lietuvos žuvys [Fishes of Lithuania]. Vilnius: Trys žvaigždutės, pp 192. [In Lithuanian]

Vooren C. 1972. Ecological aspects of the introduction of fish species into natural habitats in Europe, with special reference to the Netherlands. J Fish Biol 4(4):565-583. doi:10.1111/j.1095-8649.1972.tb05702.x

Vriese FT, Semmekrot S, Raat AJP. 1994. Assessment of spawning and nursery areas in the River Meuse. Wat Sci Technol 29(3):297-299. doi:10.2166/wst.1994.0124

Way K, Bark SJ, Longshaw CB, Denham KL, Dixon PF, Feist SW, Gardiner R, Gubbins MJ, Le Deuff RM, Martin PD, Stone DM, Taylor GR. 2003. Isolation of a rhabdovirus during outbreaks of disease in cyprinid fish species at fishery sites in England. Dis Aquat Org 57:43-50. doi:10.3354/dao057043 
Wawrzyniak W, Czerniejewski P, Neja Z, Raczyński M, Król S, Kiełpiński M, Szulc M, Tomaszkiewicz A. 2017. Program badań na Zalewie Szczecińskim i Jeziorze Dąbie w roku 2017 polegający na ocenie stanu zasobów ryb, ze szczególnym uwzględnieniem populacji sandacza, okonia, płoci i leszcza. [Research program on the Szczecin Lagoon and Lake Dąbie in 2017 consisting in assessing the state of fish stocks, with particular focus on the pikeperch, perch, roach and bream population]. Raport ZUT na zlecenie MGMiŻŚS, 167 pp. [In Polish.]

Wheeler AC. 1978. Key to the fishes of northern Europe: A guide to the identification of more than 350 species. Frederick Warne, London, pp 380.

Wheeler AC, Maitland PS. 1973. The scarcer freshwater fishes of the British Isles I. Introduced species. J Fish Biol 5(1):49-68. doi:10.1111/j.1095-8649.1973.tb04430.x

Winfield IJ, Nelson JS. 1991. Cyprinid fishes: systematics, biology and exploitation. Fish and Fisheries, Series 3. Chapman and Hall, London.

Winter HV, Fredrich F. 2003. Migratory behaviour of ide: a comparison between the lowland rivers Elbe, Germany, and Vecht, The Netherlands. J Fish Biol 63(4):871-880. doi:j.10958649.2003.00193.x

Witeska M, Sarnowski P, Lugowska K, Kowal E. 2014. The effects of cadmium and copper on embryonic and larval development of ide Leuciscus idus L. Fish Physiol Biochem 40(1):151-163. doi:10.1007/s10695-013-9832-4

Witkowski A, Cieśla M, Napora K. 1997. Jaź [Ide]. Wydawnictwo Instytutu Rybactwa Śródlądowego w Olsztynie, Olsztyn-Kortowo. [In Polish.]

Witkowski A, Kotusz J, Przybylski M. 2009. Stopien zagrozenia slodkowodnej ichtiofauny Polski: Czerwona lista minogow i ryb - stan 2009 [The degree of threat to the freshwater 
ichthyofauna of Poland: Red list of fishes and lampreys - situation in 2009]. Chrońmy Przyrodę Ojczystą 65(1):33-52. [In Polish.]

Witkowski A, Kotusz J, Wawer K, Stefaniak J, Popiołek M, Błachuta J. 2015. A natural hybrid of Leuciscus leuciscus (L.) and Alburnus alburnus (L.) (Osteichthyes: Cyprinidae) from the $\begin{array}{lllll}\text { Bystrzyca } & \text { River } & \text { (Poland). } & \text { Ann }\end{array}$ doi:10.3161/00034541ANZ2015.65.2.010

Wolter C, Kirschbaum F, Ludwig A. 2003. Sub-population structure of common fish species in the Elbe River estimated from DNA analysis. J Appl Ichthyol 19(5):278-283. doi:10.1046/j.1439-0426.2003.00495.x

Wołos A, Draszkiewicz-Mioduszewska H, Mickiewicz M. 2020. Gospodarka rybacka w śródlądowych wodach płynących w 2018 r. Cz. 1. Uprawnieni do rybactwa, obwody rybackie, połowy gospodarcze, zatrudnienie i połowy amatorskie. [Fisheries management in inland waters flowing in 2015 Vol. 1. Eligible for fisheries, fishing districts, economic fishing, employment and recreationl fishing] Komunikaty Rybackie 1(174)/2020:13-22. [In Polish.]

Yadrenkina EN. 2003. Hybridization between the native species of Lake Chany basin, the Siberian roach Rutilus rutilus and the ide Leuciscus idus. Vopr ikhtiol 43:110-117. [In Russian.]

Zhokhov AE. 2003. Seasonal dynamics of the structure of intestinal helminth community in ide (Leuciscus idus L.) from the Rybinsk Reservoir. Russ J Ecol 34(6):413-417. doi:10.1023/A:1027316602000

Zhukov PI. 1958. Ryby basejna Nemana (v predelach Belorusskoj SSR) [Neman Basin Fish (within the Belarussian SSR)] Izd. AN BSSR Minsk, pp. 1-191. [In Russian.]

Zhukov PI. 1965. Fishes of Belarus. Nauka i Tekhnika, Minsk. [In Russian.] 
Zhuravlev VB and Solovov VP. 1984. Biology and commercial significance of ide Leuciscus $i d u s$, in the upper reaches of the Ob river. Vopr Ikhtiol 24(2):232-237 (in Russian)

Zhigileva ON, Ozhirel'ev VV, Brol' IS, Pozhidaev VV. 2010. Populational structure of three fish species (Cypriniformes: Cyprinidae) living in rivers of the Ob-Irtysh basin, by the data of isoenzyme analysis. J Ichthyol 50(9):778-787. doi:10.1134/S0032945210090110

Zinov'ev EA. 1965. Ide of the Kama Reservoir. Uch Zap Permsk Univ 125:45-60 [In Russian.]

Zitek A, Schmutz S, Unfer G, Ploner A (2004a) Fish drift in a Danube sidearm-system: I. Site, inter- and intraspecific patterns. J Fish Biol 65(5):1319-1338. doi:10.1111/j.00221112.2004.00533.x

Zitek A, Schmutz S, Ploner, A. (2004b) Fish drift in a Danube sidearm-system: II. Seasonal and diurnal patterns. J Fish Biol 65(5):1339-1357. doi:10.1111/j.0022-1112.2004.00534.x

Zygmunt G. 1999. Rodzaj pokarmu naturalnego pobieranego przez jazia (Leuciscus idus) w przesadce pierwszej [Type of natural food taken by the ide (Leuciscus idus) at first transition]. MSc Thesis, Szkoła Główna Gospodarstwa Wiejskiego, Wydział Zootechniczny, Warszawa, 50 pp. [In Polish.] 


\section{Tables}

Table 1. Growth of ide Leuciscus idus as modelled by the von Bertalanffy Growth Function. For each 'best-fit' model, parameter estimates are provided including SE (standard errors) and 95\% lower and upper confidence intervals (LCI and UCI, respectively). $\mathrm{SL}_{\infty}=$ asymptotic standard length (mm); $K=$ Brody's growth coefficient $\left(\right.$ years $\left.^{-1}\right) ; t_{0}=$ age of fish at $0 \mathrm{~mm} \mathrm{SL} . n=$ number of mean LAA values (see Table A3); $N=$ number of populations. Statistically significant parameters in bold. Climate classes and types as defined in Appendix Table S1 in Electronic Supplementary Material. See also Fig. 2a-d.

\begin{tabular}{lrrrrrr}
\hline Parameter & Estimate & SE & LCI & UCI & $t$ & $P$ \\
\hline Global $(n=733, N=87)$ & & & & & & \\
SL $_{\infty}$ & 422.4 & 9.2 & 405.0 & 442.6 & 45.66 & $<\mathbf{0 . 0 0 1}$ \\
$K$ & 0.17 & 0.01 & 0.15 & 0.18 & 17.68 & $<\mathbf{0 . 0 0 1}$ \\
$t_{0}$ & 0.06 & 0.10 & -0.15 & 0.24 & 0.53 & 0.571
\end{tabular}

Habitat (Lentic: $n=263, N=29$; Lotic: $n=470, N=58$ )

$\begin{array}{lrrrrrr}\mathrm{SL}_{\infty_{\text {Lentic }}} & 399.1 & 9.3 & 382.1 & 419.5 & 42.89 & <\mathbf{0 . 0 0 1} \\ \mathrm{SL}_{\infty_{\text {Lotic }}} & 495.1 & 24.3 & 454.7 & 543.6 & 20.36 & <\mathbf{0 . 0 0 1} \\ K_{\text {Lentic }} & 0.19 & 0.01 & 0.16 & 0.21 & 15.42 & <\mathbf{0 . 0 0 1} \\ K_{\text {Lotic }} & 0.12 & 0.01 & 0.10 & 0.14 & 10.69 & <\mathbf{0 . 0 0 1} \\ t_{0} & -0.07 & 0.11 & -0.29 & 0.12 & -0.64 & 0.522\end{array}$

Climate class (B: $n=11, N=2 ; \mathrm{C}: n=298, N=42 ; \mathrm{D}: n=339, N=33$ )

$\begin{array}{lrrrrrr}\mathrm{SL}_{\infty_{\mathrm{B}}} & 524.1 & 34.2 & 458.8 & 592.4 & 15.32 & <\mathbf{0 . 0 0 1} \\ \mathrm{SL}_{\infty_{\mathrm{C}}} & 390.0 & 10.2 & 371.6 & 410.5 & 38.06 & <\mathbf{0 . 0 0 1} \\ \mathrm{SL}_{\infty_{\mathrm{D}}} & 420.9 & 9.0 & 404.8 & 438.9 & 47.76 & <\mathbf{0 . 0 0 1} \\ K & 0.17 & 0.01 & 0.15 & 0.19 & 16.83 & <\mathbf{0 . 0 0 1} \\ t_{0} & 0.06 & 0.10 & -0.14 & 0.25 & 0.62 & 0.534\end{array}$

Climate type D (Dfa: $n=7, N=1$; Dfb: $n=222, N=23$; Dfc: $n=110, N=9$ )

$\begin{array}{lrrrrrr}\mathrm{SL}_{\infty_{D f a}} & 497.9 & 29.2 & 442.0 & 555.9 & 17.07 & <\mathbf{0 . 0 0 1} \\ \mathrm{SL}_{\infty} \mathrm{Dfb} & 439.8 & 8.3 & 424.9 & 455.9 & 52.96 & <\mathbf{0 . 0 0 1} \\ \mathrm{SL}_{{ }_{\infty} \mathrm{Dfc}} & 383.4 & 7.9 & 368.9 & 399.0 & 48.31 & <\mathbf{0 . 0 0 1} \\ K & 0.18 & 0.01 & 0.16 & 0.20 & 18.86 & <\mathbf{0 . 0 0 1} \\ t_{0} & 0.25 & 0.10 & 0.04 & 0.43 & 2.44 & \mathbf{0 . 0 1 5}\end{array}$


Table 2. Condition factor $K$ for ide at various native range locations. Decimal points as per source study.

\begin{tabular}{llrrrl}
\hline Water body & Country & Mean & Min & Max & Reference \\
\hline River Nasva & Estonia & 1.50 & 1.29 & 1.65 & Kangur (1963) \\
River Dvina & Belarus & 2.38 & 2.00 & 2.75 & Zhukov (1965) \\
River Dnieper & Belarus & 2.18 & 1.71 & 2.47 & Zhukov (1965) \\
River Nemunas & Belarus & 2.09 & 1.76 & 2.50 & Zhukov (1965) \\
(Several) & Estonia & 2.1 & 1.57 & 3.51 & Ristkok (1974) \\
(Several) & Estonia & - & 1.6 & 2.2 & Järvalt (1981) \\
River Ob & Russia & 2.04 & 1.79 & 2.36 & Zhuravlev and Solovov (1984) \\
Lake Barselvann (1994) & Norway & 1.16 & - & - & Simonsen (2000) \\
Lake Barselvann (2000) & Norway & 1.18 & 0.79 & 1.47 & Simonsen (2000) \\
(Several) & Croatia & 1.060 & 1.050 & 1.070 & Treer et al. (2009) \\
Kopački Rit Nature Park & Croatia & 1.211 & 0.888 & 1.44 & Jelkić et al. (2010) \\
Yser, Meuse and Scheldt basins & Belgium & 1.08 & 0.46 & 1.85 & Hoc opus \\
\hline
\end{tabular}


Table 3. Total length-weight relationship $\left(\mathrm{W}=a \mathrm{TL}^{b}\right)$ parameters for ide at various native range locations.

\begin{tabular}{|c|c|c|c|c|c|c|}
\hline Water body & Country & Length & $a$ & & $b$ & Reference \\
\hline Lake Chany & Russia & $\mathrm{SL}$ & $\mathrm{cm}$ & 0.0054 & 3.396 & Tyurin (1927) fide Froese and Pauly (2019) \\
\hline River Volkhov & Russia & SL & $\mathrm{cm}$ & 0.0071 & 3.259 & Tyurin (1927) fide Froese and Pauly (2019) \\
\hline River Volga & Russia & SL & $\mathrm{cm}$ & 0.01574 & 2.444 & Gundrizer (1958) fide Froese and Pauly (2019) \\
\hline Western Siberia & Russia & TL & $\mathrm{cm}$ & 0.01760 & 3.066 & Gundrizer (1958) fide Froese and Pauly (2019) \\
\hline Western Siberia & Russia & $\mathrm{TL}$ & $\mathrm{cm}$ & 0.0040 & 3.468 & Gundrizer (1958) fide Froese and Pauly (2019) \\
\hline River Enisey & Russia & TL & $\mathrm{cm}$ & 0.02940 & 2.878 & Podlesnyi (1958) fide Froese and Pauly (2019) \\
\hline River Kävlinge & Sweden & $\mathrm{TL}$ & $\mathrm{mm}$ & 0.0037 & 3.339 & Cala 1970 \\
\hline River Danube sidearm Žofín & Slovakia & SL & $\mathrm{mm}$ & 0.0004 & 2.864 & Naiksatam (1976) fide Hensel (2015) \\
\hline Rivulet Bystřice & Czechia & SL & $\mathrm{mm}$ & 0.0112 & 3.1422 & Hanel (1984) \\
\hline (Unspecified) & Finland & $\mathrm{TL}$ & $\mathrm{cm}$ & 0.01185 & 2.878 & Koli (1990) fide Froese and Pauly (2019) \\
\hline (Several) & Netherlands & na & na & 0.003489 & 3.3630 & Klein Breteler and de Laak (2003) \\
\hline Lake Sailimu & China & SL & $\mathrm{mm}$ & 0.0087 & 3.3999 & Fan and Quan (2008) \\
\hline (Several) & Croatia & $\mathrm{TL}$ & $\mathrm{cm}$ & 0.0092 & 3.048 & Treer et al. (2008) \\
\hline River Ergis & China & $\mathrm{TL}$ & $\mathrm{cm}$ & 0.017 & 3.099 & Huo et al. (2011) \\
\hline Flanders & Belgium & $\mathrm{TL}$ & $\mathrm{cm}$ & 0.0054 & 3.256 & Verreycken et al. (2011) \\
\hline Lower River Irtysh & Russia & SL & $\mathrm{cm}$ & 0.0212 & 3.0269 & Liberman and Chemagin (2017) \\
\hline
\end{tabular}


Table 4. Age (years) and SL (mm) at maturity for ide at various native range locations.

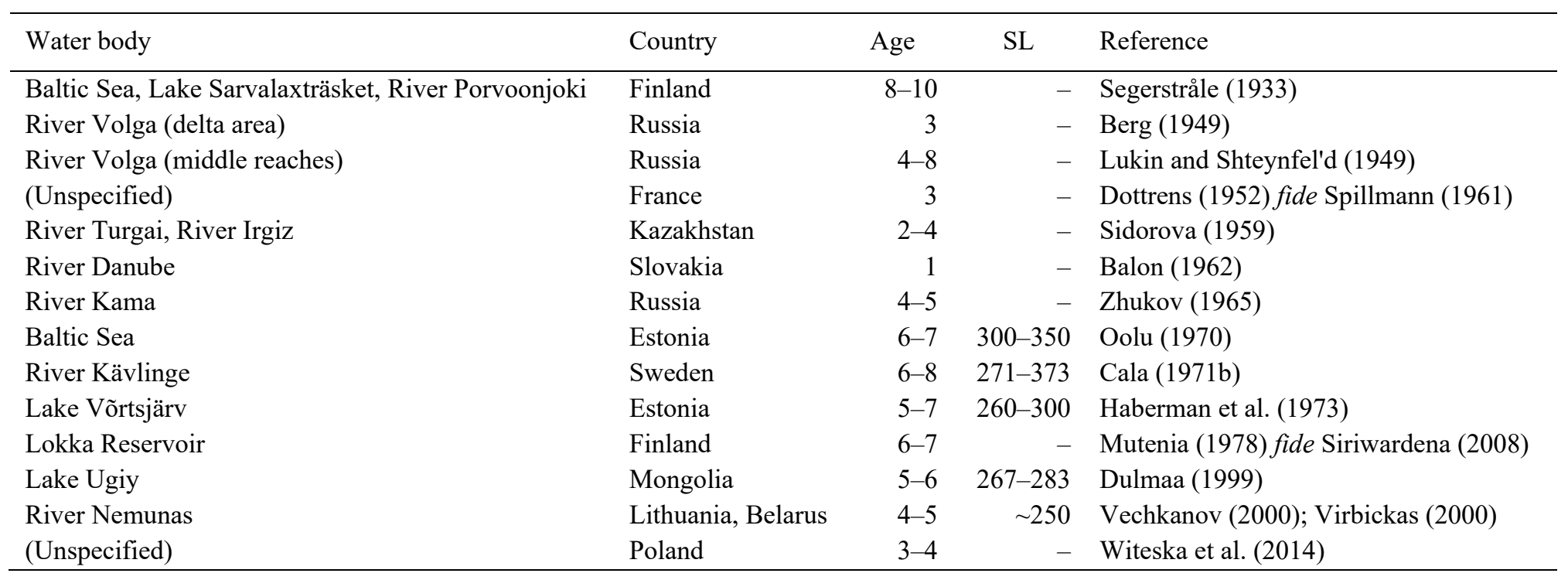


Table 5. Reported mature egg size (mm) and absolute fecundity (AF) for ide at various native and introduced (UK) locations

\begin{tabular}{|c|c|c|c|c|}
\hline Water body & Country & Egg size & $\mathrm{AF}$ & Reference \\
\hline (Unspecified) & France & 2.5 & - & Dottrens (1952) fide Spillmann (1961) \\
\hline Lake Võrtsjärv & Estonia & $1.4-1.8$ & $16,820-108,300$ & Pihu (1960) \\
\hline (Unspecified) & Romania & - & $15,000-125,000$ & Bănărescu (1964) \\
\hline River Kävlinge & Sweden & $1.4-2.1$ & $42,279-263,412$ & Cala $(1971 b, c)$ \\
\hline River Ob (upper reaches) & Russia & $1.5-1.8$ & $36,722-167,772$ & Zhuravlev and Solovov (1984) \\
\hline River Kasari, River Nasva & Estonia & - & $213,700-247,200$ & Erm and Kangur (1985) \\
\hline (Unspecified) & UK & - & $39,000-114,000$ & Maitland and Campbell (1992) \\
\hline River Orhon & Mongolia & - & $70,300-173,600$ & Dulmaa (1999) \\
\hline River Nemunas & Lithuania & $1.9-2.3$ & $35,000-150,000$ & Virbickas (2000) \\
\hline (Unspecified) & France & 2.5 & $60,000-160,000$ & Keith and Allardi (2001) \\
\hline River Dnieper & Russia & - & $39,000-114,000$ & Berg (1964) \\
\hline (Unspecified) & France & $1.9-2.3$ & - & Keith et al. (2011) \\
\hline
\end{tabular}


Fig. 1 Native (grey) and introduced (red) distributional ranges of ide Leuciscus idus in Europe. Adapted from Freyhof and Kottelat (2008) and updated with information from Cala (1970), Järvalt et al. (2003) and Bogutskaya and Naseka (2006).

Fig. 2 Growth in length of ide at the global scale as described by the von Bertalanffy growth intervals. Points in the scatterplots (except for the global fit) are slightly jittered to improve visibility. Parameters in Table 1. 


\section{Appendix}

\section{Age and growth modelling}

Data on ide growth were retrieved from both primary and secondary (cf. fide) literature sources. A necessary condition for inclusion of a literature source was that it provided mean length-atage (LAA) values for the population under study. Whenever mean LAA values were provided for only one or a few age classes (e.g. as representative of the population from which fish were sampled), these were still included into the global database for the sake of completeness (cf. Vilizzi and Copp 2017). For these analyses (and in other relevant parts of the present study), LAA data originally given as total length (TL, mm) were converted to standard length (SL, $\mathrm{mm}$ ) using the formula $\mathrm{SL}=-0.36+0.863 \mathrm{TL}$ (M. Rohtla, unpublished data).

The latitude and longitude of the water body where each ide population was sampled were recorded, except for those 'large' rivers for which no specific indication was provided of the sampling location(s). Sections of rivers or sampling locations therein were considered as separate water bodies (cf. ide populations). The distributional range of ide was then categorised as either 'native' or 'non-native' (Fig. 1). For each water body, the corresponding habitat was labelled as either 'lentic' (natural lakes and man-made reservoirs) or 'lotic' (water courses). Based on the waterbody latitude and longitude, the corresponding Köppen-Geiger climate class and type (Peel et al. 2007) were identified with reference to a regular 0.5 degree latitude/longitude grid for the period 1951-2000 (Kottek et al. 2006: http://koeppen-geiger.vuwien.ac.at/data/Koeppen-Geiger-ASCII.zip).

Growth models were based on the Beverton-Holt parameterisation of the von Bertalanffy growth function (VBGF: Ricker 1975):

$$
\mathrm{SL}=\mathrm{SL}_{\infty}\left(1-\mathrm{e}^{(-K(\operatorname{age}-t 0))}\right)
$$

where $\mathrm{SL}_{\infty}$ is the asymptotic $\mathrm{SL}, K$ the instantaneous growth rate or Brody's growth coefficient $\left(\right.$ years $^{-1}$ ), and $t_{0}$ the age of the fish at $0 \mathrm{~mm}$ SL. Following Vilizzi \& Copp (2017), 
VBGF-based comparisons in growth of ide populations between ranges, habitats, climates classes and climate D types (see Table A1) were made by fitting eight models in total: i) a general model with separate parameter estimates for each population; ii) three models with one (and with additional code written by LV). 
Table A1 Water bodies for which length-at-age data for ide were retrieved. For each water body, the country, latitude, longitude, species' distributional range, habitat and Köppen-Geiger climate class and type are provided (after Peel et al. 2007). Class: $\mathrm{B}=\mathrm{Arid}$; $\mathrm{C}=\mathrm{Temperate}$; $\mathrm{D}=$ Continental. Type: BSk $=($ Arid $)$ Steppe - Cold; Cfa $=($ Temperate $)$ Without dry season - Hot summer; Cfb $=($ Temperate $)$ Without dry season Warm summer; Dfa $=($ Continental $)$ Without dry season - Hot summer; Dfb $=($ Continental $)$ Without dry season - Warm summer; Dfc $=($ Continental $)$ Without dry season - Cold summer.

\begin{tabular}{|c|c|c|c|c|c|c|c|c|}
\hline \multirow[b]{2}{*}{ ID } & \multirow[b]{2}{*}{ Water body } & \multirow[b]{2}{*}{ Country } & \multirow[b]{2}{*}{ Lat } & \multirow[b]{2}{*}{ Lon } & \multirow[b]{2}{*}{ Range } & \multirow[b]{2}{*}{ Habitat } & \multicolumn{2}{|c|}{ Climate } \\
\hline & & & & & & & Class & Type \\
\hline 1 & Baltic Sea (Orrengrund) & Finland & $60^{\circ} 16^{\prime} \mathrm{N}$ & $26^{\circ} 26^{\prime} \mathrm{E}$ & Native & Lentic & $\mathrm{D}$ & $\mathrm{Dfb}$ \\
\hline 2 & Baltic Sea (Pellinki) & Finland & $60^{\circ} 13^{\prime} \mathrm{N}$ & $25^{\circ} 52^{\prime} \mathrm{E}$ & Native & Lentic & $\mathrm{D}$ & $\mathrm{Dfb}$ \\
\hline 3 & Baltic Sea (Väinameri) & Estonia & $58^{\circ} 87^{\prime} \mathrm{N}$ & $23^{\circ} 28^{\prime} \mathrm{E}$ & Native & Lentic & $\mathrm{D}$ & $\mathrm{Dfb}$ \\
\hline 4 & Kamskoe Reservoir & Russia & $55^{\circ} 12^{\prime} \mathrm{N}$ & $49^{\circ} 16^{\prime} \mathrm{E}$ & Native & Lentic & $\mathrm{D}$ & $\mathrm{Dfb}$ \\
\hline 5 & Král'ová Reservoir & Slovakia & $48^{\circ} 12^{\prime} \mathrm{N}$ & $17^{\circ} 48^{\prime} \mathrm{E}$ & Native & Lentic & $\mathrm{C}$ & $\mathrm{Cfb}$ \\
\hline 6 & Kremenchuk Reservoir & Ukraine & $49^{\circ} 16^{\prime} \mathrm{N}$ & $32^{\circ} 38^{\prime} \mathrm{E}$ & Native & Lentic & $\mathrm{D}$ & $\mathrm{Dfb}$ \\
\hline 7 & Kuybyshev Reservoir & Russia & $53^{\circ} 46^{\prime} \mathrm{N}$ & $48^{\circ} 55^{\prime} \mathrm{E}$ & Native & Lentic & $\mathrm{D}$ & $\mathrm{Dfb}$ \\
\hline 8 & Lake Arresø & Denmark & $56^{\circ} 00^{\prime} \mathrm{N}$ & $12^{\circ} 04^{\prime} \mathrm{E}$ & Native & Lentic & $\mathrm{C}$ & $\mathrm{Cfb}$ \\
\hline 9 & Lake Barselvann & Norway & $58^{\circ} 10^{\prime} \mathrm{N}$ & $08^{\circ} 08^{\prime} \mathrm{E}$ & Non-native & Lentic & $\mathrm{C}$ & $\mathrm{Cfb}$ \\
\hline 10 & Lake Chany & Russia & $54^{\circ} 50^{\prime} \mathrm{N}$ & $77^{\circ} 40^{\prime} \mathrm{E}$ & Native & Lentic & $\mathrm{D}$ & $\mathrm{Dfb}$ \\
\hline 11 & Lake Dzhalangash & Kazakhstan & $48^{\circ} 83^{\prime} \mathrm{N}$ & $62^{\circ} 01^{\prime} \mathrm{E}$ & Native & Lentic & $\mathrm{B}$ & BSk \\
\hline 12 & Lake Ilmen & Russia & $58^{\circ} 16^{\prime} \mathrm{N}$ & $31^{\circ} 17^{\prime} \mathrm{E}$ & Native & Lentic & $\mathrm{D}$ & $\mathrm{Dfb}$ \\
\hline 13 & Lake Kamyš-Samarské & Kazakhstan & $51^{\circ} 14^{\prime} \mathrm{N}$ & $51^{\circ} 22^{\prime} \mathrm{E}$ & Native & Lentic & $\mathrm{D}$ & Dfa \\
\hline 14 & Lake Längelmävesi & Finland & $61^{\circ} 34^{\prime} \mathrm{N}$ & $24^{\circ} 25^{\prime} \mathrm{E}$ & Native & Lentic & $\mathrm{D}$ & Dfc \\
\hline 15 & Lake Peipus & Estonia & $58^{\circ} 41^{\prime} \mathrm{N}$ & $27^{\circ} 29^{\prime} \mathrm{E}$ & Native & Lentic & $\mathrm{D}$ & $\mathrm{Dfb}$ \\
\hline 16 & Lake Sarvalaxträsket & Finland & $60^{\circ} 44^{\prime} \mathrm{N}$ & $26^{\circ} 12^{\prime} \mathrm{E}$ & Native & Lentic & $\mathrm{D}$ & $\mathrm{Dfb}$ \\
\hline 17 & Lake Sayram & China & $44^{\circ} 36^{\prime} \mathrm{N}$ & $81^{\circ} 12^{\prime} \mathrm{E}$ & Non-native & Lentic & $\mathrm{D}$ & $\mathrm{Dfb}$ \\
\hline 18 & Lake Skårsvatnet & Norway & $60^{\circ} 24^{\prime} \mathrm{N}$ & $06^{\circ} 13^{\prime} \mathrm{E}$ & Native & Lentic & $\mathrm{D}$ & $\mathrm{Dfc}$ \\
\hline 19 & Lake Štrbské Pleso & Slovakia & $49^{\circ} 07^{\prime} \mathrm{N}$ & $20^{\circ} 03^{\prime} \mathrm{E}$ & Native & Lentic & $\mathrm{D}$ & $\mathrm{Dfc}$ \\
\hline
\end{tabular}




\begin{tabular}{|c|c|c|c|c|c|c|c|c|}
\hline \multirow[b]{2}{*}{ ID } & \multirow[b]{2}{*}{ Water body } & \multirow[b]{2}{*}{ Country } & \multirow[b]{2}{*}{ Lat } & \multirow[b]{2}{*}{ Lon } & \multirow[b]{2}{*}{ Range } & \multirow[b]{2}{*}{ Habitat } & \multicolumn{2}{|c|}{ Climate } \\
\hline & & & & & & & Class & Type \\
\hline 20 & Lake Suzhargan & Kazakhstan & $49^{\circ} 46^{\prime} \mathrm{N}$ & $63^{\circ} 38^{\prime} \mathrm{E}$ & Native & Lentic & $\mathrm{B}$ & BSk \\
\hline 21 & Lake Tarankol & Kazakhstan & $53^{\circ} 71^{\prime} \mathrm{N}$ & $67^{\circ} 79^{\prime} \mathrm{E}$ & Native & Lentic & $\mathrm{D}$ & $\mathrm{Dfb}$ \\
\hline 22 & Lake Võrtsjärv & Estonia & $58^{\circ} 17^{\prime} \mathrm{N}$ & $26^{\circ} 02^{\prime} \mathrm{E}$ & Native & Lentic & $\mathrm{D}$ & $\mathrm{Dfb}$ \\
\hline 23 & Laytham Park ponds & United Kingdom & $53^{\circ} 86^{\prime} \mathrm{N}$ & $00^{\circ} 87^{\prime} \mathrm{W}$ & Non-native & Lentic & $\mathrm{C}$ & $\mathrm{Cfb}$ \\
\hline 24 & Mietkowski Lake & Poland & $50^{\circ} 57^{\prime} \mathrm{N}$ & $16^{\circ} 37^{\prime} \mathrm{E}$ & Native & Lentic & $\mathrm{C}$ & $\mathrm{Cfb}$ \\
\hline 25 & Pond near Rusovce (Bratislava) & Slovakia & $48^{\circ} 08^{\prime} \mathrm{N}$ & $17^{\circ} 06^{\prime} \mathrm{E}$ & Native & Lentic & $\mathrm{C}$ & $\mathrm{Cfb}$ \\
\hline 26 & Pond near Vlčie hrdlo (Bratislava) & Slovakia & $48^{\circ} 08^{\prime} \mathrm{N}$ & $17^{\circ} 06^{\prime} \mathrm{E}$ & Native & Lentic & $\mathrm{C}$ & $\mathrm{Cfb}$ \\
\hline 27 & River Barbarka & Poland & $51^{\circ} 13^{\prime} \mathrm{N}$ & $20^{\circ} 02^{\prime} \mathrm{E}$ & Native & Lotic & $\mathrm{C}$ & $\mathrm{Cfb}$ \\
\hline 28 & River Czarna Konecka & Poland & $51^{\circ} 18^{\prime} \mathrm{N}$ & $19^{\circ} 54^{\prime} \mathrm{E}$ & Native & Lotic & $\mathrm{C}$ & $\mathrm{Cfb}$ \\
\hline 29 & River Czarna Taraska & Poland & $51^{\circ} 06^{\prime} \mathrm{N}$ & $20^{\circ} 21^{\prime} \mathrm{E}$ & Native & Lotic & $\mathrm{C}$ & $\mathrm{Cfb}$ \\
\hline 30 & River Danube & Slovakia & - & - & Native & Lotic & - & - \\
\hline 31 & River Danube (Břeclav) & Czechia & $48^{\circ} 45^{\prime} \mathrm{N}$ & $16^{\circ} 52^{\prime} \mathrm{E}$ & Native & Lotic & $\mathrm{C}$ & $\mathrm{Cfb}$ \\
\hline 32 & River Danube (Koviljsko-Petrovaradinski Rit) & Serbia & $45^{\circ} 14^{\prime} \mathrm{N}$ & $20^{\circ} 01^{\prime} \mathrm{E}$ & Native & Lotic & $\mathrm{C}$ & Cfa \\
\hline 33 & River Danube (Kravany) & Slovakia & $48^{\circ} 59^{\prime} \mathrm{N}$ & $20^{\circ} 12^{\prime} \mathrm{E}$ & Native & Lotic & $\mathrm{D}$ & $\mathrm{Dfb}$ \\
\hline 34 & River Danube (Lake Lion) & Slovakia & $47^{\circ} 46^{\prime} \mathrm{N}$ & $17^{\circ} 43^{\prime} \mathrm{E}$ & Native & Lotic & $\mathrm{C}$ & $\mathrm{Cfb}$ \\
\hline 35 & River Danube (Little Danube near Bratislava) & Slovakia & $48^{\circ} 08^{\prime} \mathrm{N}$ & $17^{\circ} 06^{\prime} \mathrm{E}$ & Native & Lotic & $\mathrm{C}$ & $\mathrm{Cfb}$ \\
\hline 36 & River Danube (Little Danube near Kolárovo) & Slovakia & $47^{\circ} 55^{\prime} \mathrm{N}$ & $17^{\circ} 59^{\prime} \mathrm{E}$ & Native & Lotic & $\mathrm{C}$ & $\mathrm{Cfb}$ \\
\hline 37 & River Danube (Little Danube, Kanál Asód) & Slovakia & $47^{\circ} 53^{\prime} \mathrm{N}$ & $18^{\circ} 00^{\prime} \mathrm{E}$ & Native & Lotic & $\mathrm{C}$ & $\mathrm{Cfb}$ \\
\hline 38 & River Danube (Medved’ov) & Slovakia & $47^{\circ} 47^{\prime} \mathrm{N}$ & $17^{\circ} 39^{\prime} \mathrm{E}$ & Native & Lotic & $\mathrm{C}$ & $\mathrm{Cfb}$ \\
\hline 39 & River Danube (Štúrovo) & Slovakia & $47^{\circ} 47^{\prime} \mathrm{N}$ & $18^{\circ} 43^{\prime} \mathrm{E}$ & Native & Lotic & $\mathrm{C}$ & $\mathrm{Cfb}$ \\
\hline 40 & River Danube (Žitava) & Slovakia & $47^{\circ} 50^{\prime} \mathrm{N}$ & $18^{\circ} 07^{\prime} \mathrm{E}$ & Native & Lotic & $\mathrm{C}$ & $\mathrm{Cfb}$ \\
\hline 41 & River Danube (Žofín branch) & Czechia & $50^{\circ} 04^{\prime} \mathrm{N}$ & $14^{\circ} 24^{\prime} \mathrm{E}$ & Native & Lotic & $\mathrm{C}$ & $\mathrm{Cfb}$ \\
\hline 42 & River Daugava & Belarus & - & - & Native & Lotic & - & - \\
\hline 43 & River Dnieper & Belarus & - & - & Native & Lotic & - & - \\
\hline 44 & River Drzewiczka & Poland & $51^{\circ} 35^{\prime} \mathrm{N}$ & $20^{\circ} 34^{\prime} \mathrm{E}$ & Native & Lotic & $\mathrm{C}$ & $\mathrm{Cfb}$ \\
\hline 45 & River Hron & Slovakia & $47^{\circ} 49^{\prime} \mathrm{N}$ & $18^{\circ} 45^{\prime} \mathrm{E}$ & Native & Lotic & $\mathrm{C}$ & $\mathrm{Cfb}$ \\
\hline 46 & River Hron (Kalná, Želiezovce, Vozokany) & Slovakia & $48^{\circ} 19^{\prime} \mathrm{N}$ & $18^{\circ} 24^{\prime} \mathrm{E}$ & Native & Lotic & $\mathrm{C}$ & $\mathrm{Cfb}$ \\
\hline
\end{tabular}




\begin{tabular}{|c|c|c|c|c|c|c|c|c|}
\hline \multirow[b]{2}{*}{ ID } & \multirow[b]{2}{*}{ Water body } & \multirow[b]{2}{*}{ Country } & \multirow[b]{2}{*}{ Lat } & \multirow[b]{2}{*}{ Lon } & \multirow[b]{2}{*}{ Range } & \multirow[b]{2}{*}{ Habitat } & \multicolumn{2}{|c|}{ Climate } \\
\hline & & & & & & & Class & Type \\
\hline 47 & River Hron (Pohronský) & Slovakia & $47^{\circ} 58^{\prime} \mathrm{N}$ & $18^{\circ} 39^{\prime} \mathrm{E}$ & Native & Lotic & $\mathrm{C}$ & $\mathrm{Cfb}$ \\
\hline 48 & River Hron (Revištské Podzámčie and Žiar) & Slovakia & $48^{\circ} 31^{\prime} \mathrm{N}$ & $18^{\circ} 43^{\prime} \mathrm{E}$ & Native & Lotic & $\mathrm{C}$ & $\mathrm{Cfb}$ \\
\hline 49 & River Ilych (Sar"yudin) & Russia & $62^{\circ} 40^{\prime} \mathrm{N}$ & $57^{\circ} 46^{\prime} \mathrm{E}$ & Native & Lotic & $\mathrm{D}$ & Dfc \\
\hline 50 & River Irtysh (lower reaches) & Russia & $58^{\circ} 11^{\prime} \mathrm{N}$ & $68^{\circ} 15^{\prime} \mathrm{E}$ & Native & Lotic & $\mathrm{D}$ & Dfc \\
\hline 51 & River Kama & Russia & - & - & Native & Lotic & - & - \\
\hline 52 & River Karakol & Kyrgyzstan & $42^{\circ} 48^{\prime} \mathrm{N}$ & $78^{\circ} 39^{\prime} \mathrm{E}$ & Native & Lotic & $\mathrm{D}$ & Dfc \\
\hline 53 & River Kasari & Estonia & $58^{\circ} 43^{\prime} \mathrm{N}$ & $23^{\circ} 59^{\prime} \mathrm{E}$ & Native & Lotic & $\mathrm{D}$ & $\mathrm{Dfb}$ \\
\hline 54 & River Kävlinge & Sweden & $55^{\circ} 43^{\prime} \mathrm{N}$ & $12^{\circ} 59^{\prime} \mathrm{E}$ & Native & Lotic & $\mathrm{C}$ & $\mathrm{Cfb}$ \\
\hline 55 & River Luciąża & Poland & $51^{\circ} 22^{\prime} \mathrm{N}$ & $19^{\circ} 51^{\prime} \mathrm{E}$ & Native & Lotic & $\mathrm{C}$ & $\mathrm{Cfb}$ \\
\hline 56 & River Nasva & Estonia & $58^{\circ} 12^{\prime} \mathrm{N}$ & $22^{\circ} 23^{\prime} \mathrm{E}$ & Native & Lotic & $\mathrm{D}$ & $\mathrm{Dfb}$ \\
\hline 57 & River Nemunas (BY) & Belarus & - & - & Native & Lotic & - & - \\
\hline 58 & River Nemunas (LT) & Lithuania & - & - & Native & Lotic & - & - \\
\hline 59 & River Numedalslågen & Norway & $59^{\circ} 29^{\prime} \mathrm{N}$ & $09^{\circ} 55^{\prime} \mathrm{E}$ & Native & Lotic & $\mathrm{D}$ & $\mathrm{Dfb}$ \\
\hline 60 & River Ob & Russia & - & - & Native & Lotic & - & - \\
\hline 61 & River Ob (upper reaches) & Russia & - & - & Native & Lotic & - & - \\
\hline 62 & River Pilica & Poland & $51^{\circ} 51^{\prime} \mathrm{N}$ & $21^{\circ} 16^{\prime} \mathrm{E}$ & Native & Lotic & $\mathrm{C}$ & $\mathrm{Cfb}$ \\
\hline 63 & River Porvoonjoki & Finland & $60^{\circ} 23^{\prime} \mathrm{N}$ & $25^{\circ} 40^{\prime} \mathrm{E}$ & Native & Lotic & $\mathrm{D}$ & $\mathrm{Dfb}$ \\
\hline 64 & River Thaya & Czechia & $48^{\circ} 37^{\prime} \mathrm{N}$ & $16^{\circ} 56^{\prime} \mathrm{E}$ & Native & Lotic & $\mathrm{C}$ & $\mathrm{Cfb}$ \\
\hline 65 & River Vakh & Russia & $60^{\circ} 48^{\prime} \mathrm{N}$ & $76^{\circ} 42^{\prime} \mathrm{E}$ & Native & Lotic & $\mathrm{D}$ & Dfc \\
\hline 66 & River Volga (Kamskoe) & Russia & $53^{\circ} 46^{\prime} \mathrm{N}$ & $48^{\circ} 55^{\prime} \mathrm{E}$ & Native & Lotic & $\mathrm{D}$ & $\mathrm{Dfb}$ \\
\hline 67 & River Volga (middle reaches) & Russia & - & - & Native & Lotic & - & - \\
\hline 68 & River Volga (mouth of River Sviyaga) & Russia & $53^{\circ} 46^{\prime} \mathrm{N}$ & $48^{\circ} 55^{\prime} \mathrm{E}$ & Native & Lotic & $\mathrm{D}$ & $\mathrm{Dfb}$ \\
\hline 69 & River Volga (Nizhny) & Russia & $56^{\circ} 19^{\prime} \mathrm{N}$ & $44^{\circ} 00^{\prime} \mathrm{E}$ & Native & Lotic & $\mathrm{D}$ & $\mathrm{Dfb}$ \\
\hline 70 & River Wąglanka & Poland & $51^{\circ} 22^{\prime} \mathrm{N}$ & $20^{\circ} 17^{\prime} \mathrm{E}$ & Native & Lotic & $\mathrm{C}$ & $\mathrm{Cfb}$ \\
\hline 71 & River Wolbórka & Poland & $51^{\circ} 32^{\prime} \mathrm{N}$ & $20^{\circ} 03^{\prime} \mathrm{E}$ & Native & Lotic & $\mathrm{C}$ & $\mathrm{Cfb}$ \\
\hline 72 & River Žitava & Slovakia & $47^{\circ} 51^{\prime} \mathrm{N}$ & $18^{\circ} 08^{\prime} \mathrm{E}$ & Native & Lotic & $\mathrm{C}$ & $\mathrm{Cfb}$ \\
\hline 73 & Rivers in Łódź region & Poland & $51^{\circ} 40^{\prime} \mathrm{N}$ & $19^{\circ} 26^{\prime} \mathrm{E}$ & Native & Lotic & $\mathrm{C}$ & $\mathrm{Cfb}$ \\
\hline
\end{tabular}




\begin{tabular}{|c|c|c|c|c|c|c|c|c|}
\hline \multirow[b]{2}{*}{ ID } & \multirow[b]{2}{*}{ Water body } & \multirow[b]{2}{*}{ Country } & \multirow[b]{2}{*}{ Lat } & \multirow[b]{2}{*}{ Lon } & \multirow[b]{2}{*}{ Range } & \multirow[b]{2}{*}{ Habitat } & \multicolumn{2}{|c|}{ Climate } \\
\hline & & & & & & & Class & Type \\
\hline 74 & Rivulet Bystřice & Czechia & $49^{\circ} 38^{\prime} \mathrm{N}$ & $18^{\circ} 43^{\prime} \mathrm{E}$ & Native & Lotic & $\mathrm{D}$ & $\mathrm{Dfb}$ \\
\hline
\end{tabular}


Table A2 Mean length-at-age (standard length: SL, mm) values for ide. Source references in footnote.

Estimated age (years)

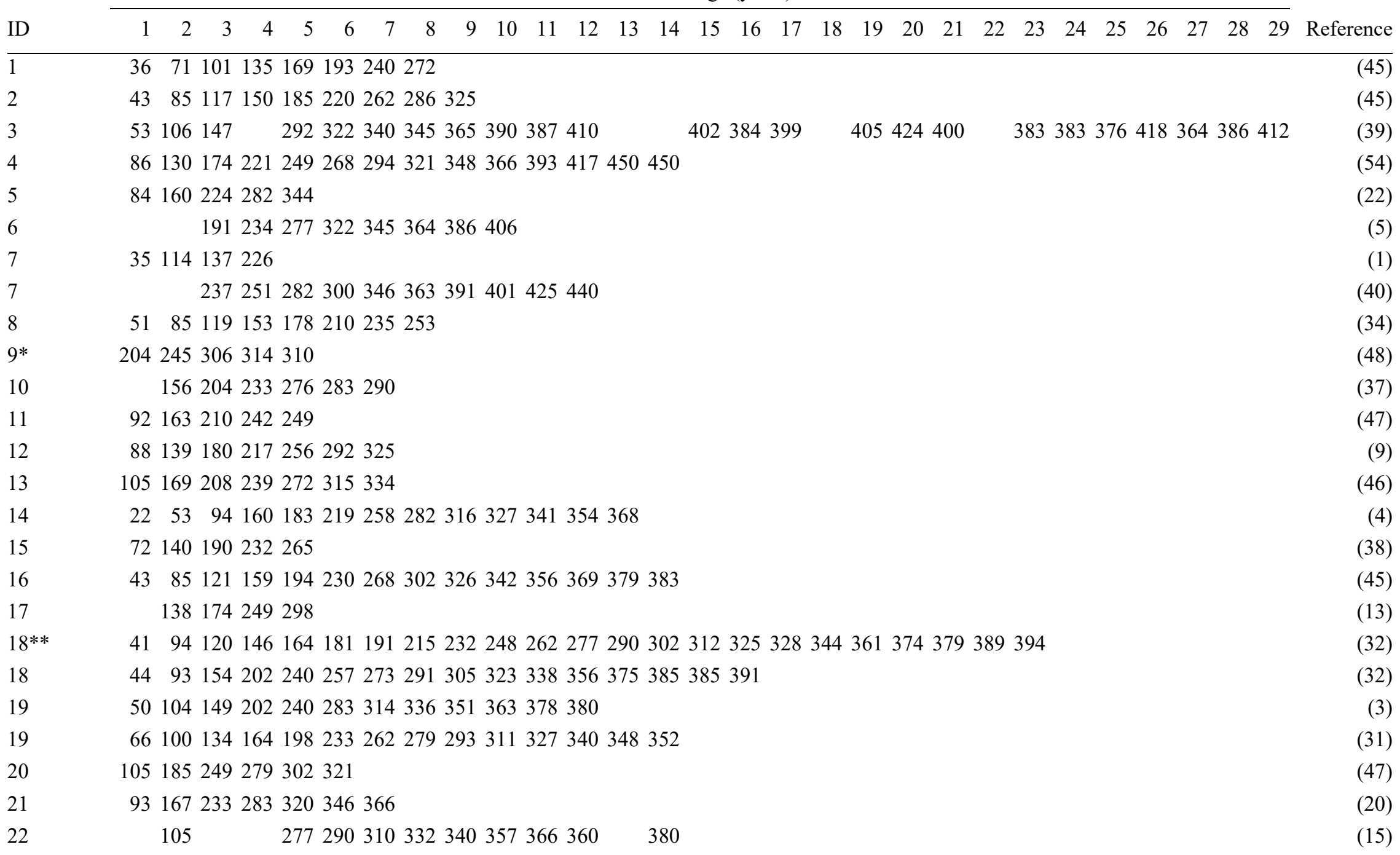


93107155169196225255276295315345364

136182215256268316328356

$51 \quad 94145184214248285$

$120145181 \quad 253$

$\begin{array}{llll}56 & 132 & 173 & 193\end{array}$

50

$64 \quad 95111172261319338$

$\begin{array}{lllllll}70 & 136 & 177 & 233 & 279 & 323 & 340\end{array}$

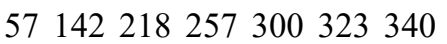

$\begin{array}{lllll}59 & 97 & 134 & 248 & 259\end{array} 297$

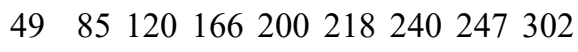

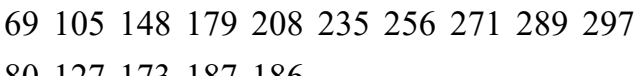

$\begin{array}{llllll}72 & 152 & 238 & 280 & 311\end{array}$

51119161174217250

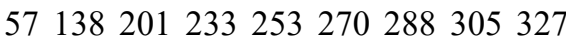

$\begin{array}{llllll}60 & 135 & 181 & 218 & 250\end{array}$

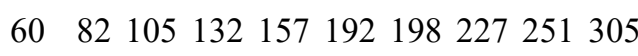

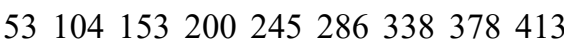

59118169211255293355383

$$
\begin{array}{lll}
105 & 167201 \quad 275279
\end{array}
$$




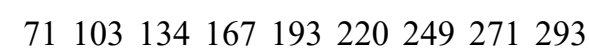

$\begin{array}{lllllllllll}29 & 58 & 85 & 117 & 152 & 175 & 206 & 228 & 253 & 288 & 297\end{array}$

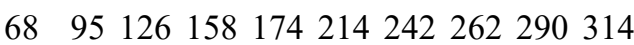

$41 \quad 85125169212252292326 \quad 355$

136197231251287310291324324

58102141174207238268

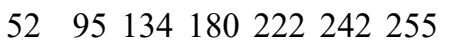

$148191 \quad 298354374387404417438447468485$

69142204260299333359377394401414

$55127180247 \quad 375378399412416$

143176173195235257298315337360390355

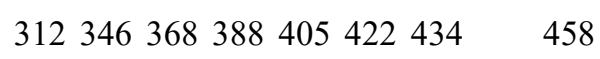

52104153198244270

65100150200270315360365390410420428455460

114158199230250265275284334

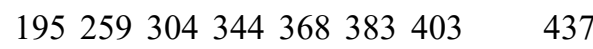

160190195207

73138177209257298320349368

103142190196220255283306327349382

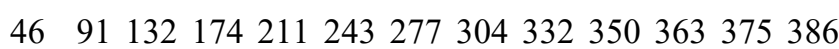

$\begin{array}{lllllllll}58 & 99 & 153 & 201 & 249 & 282 & 330 & 338 & 352\end{array}$

$\begin{array}{lllllll}50 & 99 & 133 & 163 & 198 & 234 & 260\end{array}$

58108156220250303340376390396409423

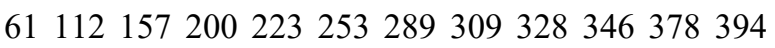

$48 \quad 94142 \quad 183223257276288313 \quad 345$

115139179213232257278319331344359383416

$186 \quad 210$

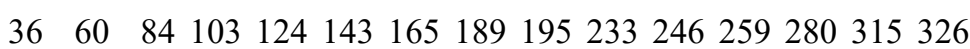

63117153193224245265295321332 
References: ${ }^{1}$ Autko (1958) fide Sayfullin and Shakirova (2014); ${ }^{2}$ Balon (1962); ${ }^{3}$ Balon and Žitňan (1964); ${ }^{4}$ Brofeldt (1917) fide Segestråle (1933); ${ }^{5}$ Brujenko et al. (1974); ${ }^{6}$ Čajka (1975) fide Hensel (2015); ${ }^{7}$ Cala (1970); ${ }^{8} \mathrm{Cala}$ (1971b); ${ }^{9}$ Domrachev and Pravdin (1926); ${ }^{10}$ Dukravets et al. (2001); ${ }^{11}$ Erm and Kangur (1985); ${ }^{12}$ Erm et al. (2002); ${ }^{13}$ Fan and Quan (2008); ${ }^{14}$ Golovko (1973) fide Sayfullin and Shakirova (2014); ${ }^{15}$ Haberman et al. (1973); ${ }^{16}$ Hanel (1984); ${ }^{17}$ Heggenes (1983); ${ }^{18}$ Hochman (1956); ${ }^{19}$ Jakubowski and Penczak (1970); ${ }^{20}$ Jereščenko (1959) fide Balon (1962); ${ }^{21}$ Kleszcz (2008); ${ }^{22}$ Kovrižnych et al. (1986) fide Hensel (2015); ${ }^{23}$ Krišofík (1961) fide Hensel (2015); ${ }^{24}$ Krupka (1972) fide Hensel (2015); ${ }^{25}$ Liberman and Chemagin (2017); ${ }^{26}$ Lujić et al. (2013); ${ }^{27}$ Lukin (1934) fide Sayfullin and Shakirova (2014); ${ }^{28}$ Menshikov and Bukiriev (1934) fide Balon (1962); ${ }^{29}$ Muromova (1930) fide Balon (1962); ${ }^{30}$ Naiksatam (1976) fide Hensel (2015); ${ }^{31}$ Nevický (1992) fide Hensel (2015); ${ }^{32}$ Nicolaisen (1996); ${ }^{33}$ Nikolsky et al. (1947); ${ }^{34}$ Otterstrøm (1930) fide Segestråle (1933); ${ }^{35}$ Peňáz (1961); ${ }^{36}$ Platonova (1958) fide Sayfullin and Shakirova (2014); ${ }^{37}$ Popov et al. (2005); ${ }^{38}$ Probatov (1929) fide Balon (1962); ${ }^{39}$ Rohtla et al. (2015b); ${ }^{40}$ Sayfullin and Shakirova (2014); ${ }^{42}$ Sedlár (1966) fide Hensel (2015); ${ }^{43}$ Sedlár (1989) fide Hensel (2015); ${ }^{44}$ Sedlár et al. (1985) fide Hensel (2015); ${ }^{45}$ Segestråle (1933); ${ }^{46}$ Serov (1959); ${ }^{47}$ Sidorova (1959); ${ }^{48}$ Simonsen (2000); ${ }^{49}$ Šindléryová (1965) fide Hensel (2015); ${ }^{50}$ Svetovidova (1949) fide Balon (1962); ${ }^{51}$ Zhukov (1958) fide Balon (1962); ${ }^{52}$ Zhukov (1965); ${ }^{53}$ Zhuravlev and Solovov (1984); ${ }^{54}$ Zinov'ev (1965) fide Sayfullin and Shakirova (2014); ${ }^{55}$ Hoc opus.

* Golden orfe escaped or translocated from a nearby amusement park pond.

** Golden orfe sympatric with wild ide. 
Table A3 List of taxa encountered in the natural diet of ide. ns = taxa not specified. Source references in footnote.

\begin{tabular}{|c|c|c|c|}
\hline Kingdom/Phylum & Class & Scientific name or lowest taxon & Reference(s) \\
\hline \multicolumn{4}{|l|}{ Protista } \\
\hline \multirow[t]{2}{*}{ Euglenozoa } & Kinetoplastea & Bodo edax & (17) \\
\hline & & Polyoecta dumosa & (17) \\
\hline \multirow[t]{8}{*}{ Ciliata } & Oligotrichida & Tintinnidum fluviatile & (17) \\
\hline & Peritrichia & Carchesium polypinum & (17) \\
\hline & & Zoothamnium sp. & (17) \\
\hline & Prostomatida & Prorodon ovum & (17) \\
\hline & Nassulida & Nassula elegans & (17) \\
\hline & Cyrtophorida & Chilodonella cucullulus & (17) \\
\hline & Hymenostomata & Colpidium colpoda & (17) \\
\hline & & Colpidium cucullus & (17) \\
\hline Protozoa incertae sedis & Protozoa incertae sedis & Cercobodo cometa & (17) \\
\hline \multicolumn{4}{|l|}{ Animalia } \\
\hline \multirow[t]{14}{*}{ Rotifera } & ns & ns & (1) \\
\hline & Bdeloida & Rotaria neptunia & (17) \\
\hline & Monogononta & Anuraeopsis fissa & (17) \\
\hline & & Asplanchna priodonta & (17) \\
\hline & & Brachionus calyciflorus & (17) \\
\hline & & Brachionus diversicornis & (17) \\
\hline & & Keratella cochlearis & (17) \\
\hline & & Keratella quadrata & (17) \\
\hline & & Lecane bulla & (17) \\
\hline & & Lecane luna & (17) \\
\hline & & Trichocerca rousseleti & (17) \\
\hline & & Trichocerca pygocera & (17) \\
\hline & & Polyarthra major & (17) \\
\hline & & Polyarthra minor & (17) \\
\hline \multirow[t]{2}{*}{ Annelida } & Clitellata & ns & $(1,6)$ \\
\hline & & Lumbricidae & $(2,8)$ \\
\hline \multirow[t]{14}{*}{ Arthropoda } & Branchiopoda & ns & $(1,8)$ \\
\hline & & Bosmina coregoni & (17) \\
\hline & & Bosmina longirostris & (17) \\
\hline & & Chydorus sphaericus & (17) \\
\hline & & Daphnia cucullata & (17) \\
\hline & & Pleuroxus uncinatus & (17) \\
\hline & & Polyphemus pediculus & (17) \\
\hline & Ostracoda & ns & $(1,17)$ \\
\hline & Maxillopoda & Canthocampus sp. & (17) \\
\hline & & Cyclops strenuus & (17) \\
\hline & & Cyclops sp. (one species?) & $(1,2,8)$ \\
\hline & & Diaptomus sp. (one species?) & (2) \\
\hline & & Mesocyclops sp. & (17) \\
\hline & Malacostraca & Asellus spp. (aquaticus) & $(1,4,9)$ \\
\hline
\end{tabular}




\begin{tabular}{|c|c|c|c|}
\hline Kingdom/Phylum & Class & Scientific name or lowest taxon & Reference(s) \\
\hline & & Gammarus spp. & $(1,4,11)$ \\
\hline & & Saduria entomon & $(4,11)$ \\
\hline & Arachnida & Hydrachnidiae & (1) \\
\hline & Insecta & Corixa spp. & $(1,8)$ \\
\hline & & Dysticus spp. & (9) \\
\hline & & Ephemeroptera (nymph) & $(1,6)$ \\
\hline & & Ephemera vulgata (nymph) & (5) \\
\hline & & Naucoris cimicoides & (8) \\
\hline & & Pentatoma rufipes & (5) \\
\hline & & Plea minutissima & (8) \\
\hline & & Tabanus spp. & (9) \\
\hline & & Trichoptera (larva) & $(1,5,12)$ \\
\hline & & Coleoptera (larva, imago) & $(1,8,12)$ \\
\hline & & Lepidoptera (larva) & (8) \\
\hline & & Odonata (nymph) & $(1,12)$ \\
\hline & & Phryganea spp. & (9) \\
\hline & & Ceratopogonidae (larva) & (1) \\
\hline & & Chironomidae (larva, pupa, imago) & $(1,2,5,8,9,11,12,17)$ \\
\hline & & Simuliidae (larva, pupa) & (1) \\
\hline \multirow[t]{24}{*}{ Mollusca } & Gastropoda & Acroloxus lacustris & (1) \\
\hline & & Anisus vortex & (1) \\
\hline & & Bathyomphalus contortus & (1) \\
\hline & & Bithynia leachii & (1) \\
\hline & & Bithynia tentaculata & $(1,11)$ \\
\hline & & Bithynia spp. & (4) \\
\hline & & Gyraulus spp. & (1) \\
\hline & & Hydrobia spp. & $(1,2,10,11)$ \\
\hline & & Lymnaea spp. & $(1,4,8)$ \\
\hline & & Physa fontinalis & (1) \\
\hline & & Planorbis carinatus & (1) \\
\hline & & Radix baltica & (10) \\
\hline & & Theodoxus fluviatilis & $(10,11)$ \\
\hline & & Viviparus fasciatus & (1) \\
\hline & & Valvata macrostoma & (1) \\
\hline & & Valvata piscinalis & (1) \\
\hline & Bivalvia & Cardium sp. (one species?) & (4) \\
\hline & & Cerastoderma glaucum & (11) \\
\hline & & Dreissena polymorpha & (12) \\
\hline & & Dreissena bugensis & (12) \\
\hline & & Macoma baltica & (10) \\
\hline & & Mya arenaria & (11) \\
\hline & & Mytilus edulis & $(1,4,7,10)$ \\
\hline & & Tellina sp. (one species?) & (4) \\
\hline \multirow[t]{2}{*}{ Chordata } & Actinopterygii & Alburnus alburnus & (13) \\
\hline & & Coregonus albula & (3) \\
\hline
\end{tabular}




\begin{tabular}{lllr}
\hline Kingdom/Phylum & Class & Scientific name or lowest taxon & Reference(s) \\
\hline & & Coregonus lavaretus (egg, juvenile) & $(10)$ \\
& & Hypophtalmichthys nobilis (juvenile) \\
& Leuciscus idus (egg, juvenile) & $(14)$ \\
& Osmerus eperlanus & $(3)$ \\
& Perca fluviatilis (juvenile) & $(1)$ \\
& & Pungitius platygaster & $(8)$ \\
Plantae & Pungitius pungitius & $(10)$ \\
Chlorophyta & Rutilus rutilus (juvenile) & $(1)$ \\
Charophyta & & & $(1)$ \\
Equisetophyta & Chlorophyceae & Cladophora & $(3)$ \\
Magnoliophyta & Charophyceae & Characeae & $(15)$ \\
& Equisetopsida & Equisetum fluviatile & $(1)$ \\
& Monocots & Carex spp. (seeds) & $(1)$ \\
& & Lemma minor & $(15)$ \\
& & Potamogeton perfoliatus & $(1)$ \\
& & Potamogeton spp. & $(1)$ \\
\hline
\end{tabular}

1702 References: ${ }^{1}$ Cala (1970); ${ }^{2}$ Collett (1905) fide Cala (1970); ${ }^{3}$ Huitfeldt-Kaas (1917) fide Cala (1970); ${ }^{4}$ Jääskeläinen 1703 (1917, 1921) fide Cala (1970); ${ }^{5}$ Mühlen and Schneider (1920) fide Järvalt et al. (2003); ${ }^{6}$ Berg (1949); ${ }^{7}$ Segerstråle 1704 (1933); ${ }^{8}$ Popescu et al. (1960) fide Cala (1970); ${ }^{9}$ Martinson (1980) fide Järvalt et al. (2003); ${ }^{10}$ Oolu (1970); ${ }^{11}$ Erm 1705 and Kangur (1985); ${ }^{12}$ Shcherbina and Buckler (2006); ${ }^{13}$ Froese and Pauly (2019); ${ }^{14}$ Sanft (2015); ${ }^{15}$ Braband 1706 (1985); ${ }^{16}$ Zhuravlev and Solovov (1984); ${ }^{17}$ Zygmunt (1999). 
Table A4 Eukaryotic parasites of ide. Taxonomy follows the World Register of Marine Species (WoRMS) database, except for Crustacea taxonomy which follows the World of Copepods database (www.marinespecies.org/copepoda/). Some taxa have been revised, so valid and verified species names are used in the list which may be different from the original record. Subgenera are not given. Data on host specificity and geographical distribution is sourced from the Host-Parasite Database of the Natural History Museum, London (www.nhm.ac.uk/research-curation/scientific-resources/taxonomy-systematics/hostparasites/database/search.jsp), recent literature in Web of Science (www.apps.webofknowledge.com/) and the World of Copepods database. The listed metazoan parasites (except Cnidaria) occur as adults, trematode metacercariae (m) and nematode larvae (l). Most records are based on morphology, which is not a reliable method of identification for some species, particularly where parasites occur as metacercariae and larvae. Parasites are generalists in the fish host unless described as specialist. Some records are specified for Cyprinidae $(*)$. Distribution data refers to any stage of the specified parasite in any of its hosts. Geographical data is subject to reporting bias. Source references in footnote.

\begin{tabular}{llll}
\hline Taxonomic groups/species & Family & Geographical distribution & Reference(s) \\
\hline Protists & & \\
\hline
\end{tabular}

\section{Protists}

Phylum: Ciliophora

Class: Oligohymenophorea

\begin{tabular}{|c|c|c|c|}
\hline Apiosoma baninae & Epistylididae & Eurasia & (1) \\
\hline Apiosoma olae & Epistylididae & Rare specialist & (1) \\
\hline Apiosoma piscicola & Epistylididae & Widespread & $(1,17)$ \\
\hline Ichthyophthirius multifiliis & Ichthyophthiriidae & Widespread & $(1.17,37)$ \\
\hline Paratrichodina incissa & Trichodinidae & Eurasia & $(1,17)$ \\
\hline Trichodina domerguei & Trichodinidae & Eurasia & (17) \\
\hline Trichodina esocis & Trichodinidae & Widespread & (1) \\
\hline Trichodina mutabilis & Trichodinidae & Widespread & (1) \\
\hline Trichodina nemachili & Trichodinidae & Eurasia & (1) \\
\hline Trichodina nigra & Trichodinidae & Widespread & (1) \\
\hline Trichodina pediculus & Trichodinidae & Widespread & (1) \\
\hline Trichodina rectangli & Trichodinidae & Eurasia & $(1,18)$ \\
\hline Trichodina reticulata & Trichodinidae & Widespread & (1) \\
\hline Trichodina rostrata & Trichodinidae & Eurasia & (1) \\
\hline
\end{tabular}




\begin{tabular}{|c|c|c|c|}
\hline Taxonomic groups/species & Family & Geographical distribution & Reference(s) \\
\hline Trichodinella subtilis & Trichodinidae & Eurasia & (17) \\
\hline Tripartiella copiosa & Trichodinidae & Widespread & $(1,5,35)$ \\
\hline \multicolumn{4}{|l|}{ Class: Phyllopharyngea } \\
\hline $\begin{array}{l}\text { Chilodonella hexasticha and } \\
\text { Chilodonella piscicola (require } \\
\text { molecular analysis for } \\
\text { discrimination) }\end{array}$ & Chilodonellidae & Widespread & $(1,5)$ \\
\hline Phylum: Euglenozoa & $\begin{array}{l}\text { Molecular data does not } \\
\text { support currently } \\
\text { recognised families. }\end{array}$ & & \\
\hline \multicolumn{4}{|l|}{ Class: Kinetoplastea } \\
\hline Cryptobia branchialis & Cryptobidae & Widespread & $(1,5)$ \\
\hline $\begin{array}{l}\text { Ichthyobodo necator species } \\
\text { complex }\end{array}$ & Bodonidae & Widespread & (1) \\
\hline Trypanosoma carassii & Trypanosomatidae & Widespread & (1) \\
\hline Trypanosoma inexpectata & Trypanosomatidae & Specialist, Volga River basin & (1) \\
\hline Trypanosoma schulmani & Trypanosomatidae & Eurasia & (1) \\
\hline \multicolumn{4}{|l|}{ Phylum: Metamonada } \\
\hline \multicolumn{4}{|l|}{ Class: Trepomonadea } \\
\hline Spironucleus vortens & Hexamitidae & Widespread & $(38)$ \\
\hline \multicolumn{4}{|l|}{ Phylum: Oomycota } \\
\hline \multicolumn{4}{|l|}{ Class: Peronosporea } \\
\hline Saprolegnia sp. & Saprolegniaceae & Widespread & (5) \\
\hline \multicolumn{4}{|l|}{ Fungi } \\
\hline \multicolumn{4}{|l|}{ Phylum: Microsporidia } \\
\hline \multicolumn{4}{|l|}{ Class: Microsporea } \\
\hline Ichthyosporidium hertwigi & Ichthyosporidiidae & Widespread & (5) \\
\hline Ichthyosporidium hoferi & Ichthyosporidiidae & Widespread & (5) \\
\hline \multicolumn{4}{|l|}{ Animalia } \\
\hline Phylum: Cnidaria & & & \\
\hline
\end{tabular}




\begin{tabular}{|c|c|c|c|}
\hline Taxonomic groups/species & Family & Geographical distribution & Reference(s) \\
\hline \multicolumn{4}{|l|}{ Class: Myxozoa } \\
\hline Chloromyxum cristatum & Chloromyxidae & Eurasia & $(1,17,18)$ \\
\hline Chloromyxum fluviatile & Chloromyxidae & Eurasia & $(1,17,37)$ \\
\hline Chloromyxum legeri & Chloromyxidae & Eurasia & (17) \\
\hline Henneguya cutanea & Myxobolidae & Eurasia & (1) \\
\hline Henneguya zschokkei & Myxobolidae & Widespread & (18) \\
\hline Myxidium macrocapsulare & Myxidiidae & Widespread & $(1,17)$ \\
\hline Myxidium rhodei & Myxidiidae & Eurasia & $(1,17,35)$ \\
\hline Myxobilatus legeri & Myxobilatidae & Eurasia & $(1,17)$ \\
\hline Myxobolus albovae & Myxobolidae & Eurasia & (1) \\
\hline Myxobolus alvarezae & Myxobolidae & Eurasia & (4) \\
\hline Myxobolus bramae & Myxobolidae & Eurasia & $(1,17)$ \\
\hline Myxobolus carassii & Myxobolidae & Eurasia & $(1,17,35)$ \\
\hline Myxobolus cycloides & Myxobolidae & Eurasia & (1) \\
\hline Myxobolus dispar & Myxobolidae & Eurasia & $(1,17,37)$ \\
\hline Myxobolus dogieli & Myxobolidae & Eurasia & (1) \\
\hline Myxobolus donecae & Myxobolidae & Eurasia & $(1,17)$ \\
\hline Myxobolus dujardini & Myxobolidae & Widespread & $(1,13,17,18)$ \\
\hline Myxobolus elegans & Myxobolidae & Eurasia & $(1,11)$ \\
\hline Myxobolus ellipsoides & Myxobolidae & Eurasia & (1) \\
\hline Myxobolus exiguus & Myxobolidae & Eurasia & $(1,20)$ \\
\hline Myxobolus gigas & Myxobolidae & Eurasia & $(1,17)$ \\
\hline Myxobolus improvisus & Myxobolidae & Eurasia & (1) \\
\hline Myxobolus intimus & Myxobolidae & Eurasia & (4) \\
\hline Myxobolus kubanicus & Myxobolidae & Eurasia & (5) \\
\hline Myxobolus kuleminae & Myxobolidae & Eurasia & (1) \\
\hline Myxobolus macrocapsularis & Myxobolidae & Eurasia & $(1,17)$ \\
\hline Myxobolus muelleri & Myxobolidae & Widespread & $(1,17,20,35,37)$ \\
\hline
\end{tabular}




\begin{tabular}{|c|c|c|c|}
\hline Taxonomic groups/species & Family & Geographical distribution & Reference(s) \\
\hline Myxobolus muelleriformis & Myxobolidae & Eurasia & (1) \\
\hline Myxobolus multiplicatus & Myxobolidae & Eurasia & $(1,17,18)$ \\
\hline Myxobolus musculi & Myxobolidae & Widespread & (1) \\
\hline Myxobolus nemetzeki & Myxobolidae & Eurasia & $(1,17,20)$ \\
\hline Myxobolus obesus & Myxobolidae & Eurasia & $(1,17)$ \\
\hline Myxobolus oviformis & Myxobolidae & Eurasia & (1) \\
\hline Myxobolus permagnus & Myxobolidae & Eurasia & (1) \\
\hline Myxobolus pseudodispar & Myxobolidae & Eurasia & (1) \\
\hline Myxobolus strelkovi & Myxobolidae & Eurasia & (1) \\
\hline Thelohanellus fuhrmanni & Myxobolidae & Eurasia & (1) \\
\hline Thelohanellus oculileucisci & Myxobolidae & Eurasia & $(1,19,37)$ \\
\hline Thelohanellus pyriformis & Myxobolidae & Eurasia & $(1,17)$ \\
\hline Zschokkella nova & Myxidiidae & Eurasia & $(1,17,35,37)$ \\
\hline Zschokkella striata & Myxidiidae & Eurasia & (5) \\
\hline \multicolumn{4}{|l|}{ Phylum: Platyhelminthes } \\
\hline \multicolumn{4}{|l|}{ Class: Cestoda } \\
\hline Caryophyllaeides fennica & Lytocestidae & Eurasia & $(3,6,17,20,24,28,40)$ \\
\hline Caryophyllaeus brachycollis & Caryophyllaeidae & Eurasia & $(3,6,12,28)$ \\
\hline Caryophyllaeus laticeps & Caryophyllaeidae & Eurasia & $(3,6,17,24,28,37)$ \\
\hline Ligula intestinalis & Diphyllobothriidae & Widespread & $(3,17)$ \\
\hline Proteocephalus torulosus & Proteocephalidae & Widespread & $(3,14,17,18,40)$ \\
\hline Schistocephalus solidus & Diphyllobothriidae & Widespread & (13) \\
\hline Schizocotyle acheilognathi & Bothriocephalidae & Widespread & (3) \\
\hline Triaenophorus nodulosus (1) & Triaenophoridae & Widespread & $(3,6,17,18)$ \\
\hline \multicolumn{4}{|l|}{ Class: Monogenea } \\
\hline Dactylogyrus alatus & Dactylogyridae & Eurasia & $(2,7,16,26,30)$ \\
\hline Dactylogyrus crucifer & Dactylogyridae & Eurasia & $(12,24)$ \\
\hline Dactylogyrus fallax & Dactylogyridae & Eurasia & $(2,20,30)$ \\
\hline
\end{tabular}




\begin{tabular}{|c|c|c|c|}
\hline Taxonomic groups/species & Family & Geographical distribution & Reference(s) \\
\hline Dactylogyrus haplogonoides & Dactylogyridae & Eurasia & (6) \\
\hline Dactylogyrus micracanthus & Dactylogyridae & Eurasia & $(2,7,16,30)$ \\
\hline Dactylogyrus nasalis & Dactylogyridae & Eurasia & $(2)$ \\
\hline Dactylogyrus ramulosus & Dactylogyridae & Eurasia & $(2,6,7,17,20,26,30)$ \\
\hline Dactylogyrus robustus & Dactylogyridae & Eurasia & $(2,6,7,17,30)$ \\
\hline Dactylogyrus similis & Dactylogyridae & Eurasia & $(2,20,24)$ \\
\hline Dactylogyrus sphyrna & Dactylogyridae & Eurasia & $(12,24)$ \\
\hline Dactylogyrus tuba & Dactylogyridae & Eurasia & $(2,6,7,12,14,16,17,20,24,30,35,37)$ \\
\hline Dactylogyrus vistulae & Dactylogyridae & Eurasia & $(26)$ \\
\hline Dactylogyrus yinwenyingae & Dactylogyridae & Eurasia & $(2,20,30)$ \\
\hline Diplozoon paradoxum & Diplozoidae & Eurasia & $(9,17,24)$ \\
\hline Gyrodactylus carassii & Gyrodactylidae & Eurasia & $(6,10,30)$ \\
\hline Gyrodactylus decorus & Gyrodactylidae & Eurasia & (36) \\
\hline Gyrodactylus laevis & Gyrodactylidae & Eurasia & $(30)$ \\
\hline Gyrodactylus leucisci & Gyrodactylidae & Eurasia & $(31)$ \\
\hline Gyrodactylus medius & Gyrodactylidae & Widespread & (17) \\
\hline Gyrodactylus prostae & Gyrodactylidae & Eurasia & $(2,6,7,9,12,17,18,20,24,30,35,37)$ \\
\hline Gyrodactylus scardiniensis & Gyrodactylidae & Eurasia & (7) \\
\hline Gyrodactylus tulensis & Gyrodactylidae & Eurasia & $(10,30)$ \\
\hline Gyrodactylus vimbi & Gyrodactylidae & Eurasia & $(30,31)$ \\
\hline Paradiplozoon alburni & Diplozoidae & Eurasia & $(2,20,30)$ \\
\hline Paradiplozoon bliccae & Diplozoidae & Eurasia & $(9,35)$ \\
\hline Paradiplozoon homoion & Diplozoidae & Eurasia & $(2,17,30)$ \\
\hline Paradiplozoon leucisci & Diplozoidae & Eurasia & (7) \\
\hline Paradiplozoon megan & Diplozoidae & Eurasia & $(2,6,7,14,17,30,35)$ \\
\hline \multicolumn{4}{|l|}{ Class: Trematoda } \\
\hline Allocreadium dogieli & Allocreadiidae & Eurasia & (3) \\
\hline Allocreadium isoporum & Allocreadiidae & Eurasia & $(17,20,25,33,34,37,40)$ \\
\hline
\end{tabular}




\begin{tabular}{|c|c|c|c|}
\hline Taxonomic groups/species & Family & Geographical distribution & Reference(s) \\
\hline Allocreadium transversale & Allocreadiidae & Eurasia & (3) \\
\hline Apharyngostrigea согnu $(\mathrm{m})$ & Strigeidae & Widespread & $\left(3^{*}\right)$ \\
\hline Apophallus muehlingi $(\mathrm{m})$ & Heterophyidae & Eurasia & $(6,14,24)$ \\
\hline Aspidogaster limacoides & Aspidogastridae & Widespread & $(17,40)$ \\
\hline Asymphylodora imitans & Lissorchiidae & Eurasia & $(3,25)$ \\
\hline Asymphylodora kubanica & Lissorchiidae & Eurasia & $(25,35)$ \\
\hline Asymphylodora markewitschi & Lissorchiidae & Eurasia & $(3,13,17,22,35,40)$ \\
\hline Asymphylodora parasquamosa & Lissorchiidae & Eurasia & $(3,25,32)$ \\
\hline Asymphylodora tincae & Lissorchiidae & Eurasia & $(17,25)$ \\
\hline Bolbophorus confusus (m) & Diplostomidae & Eurasia & $\left(3^{*}\right)$ \\
\hline Bucephalus polymorphus & Bucephalidae & Eurasia & $\left(3^{*}, 17,22\right)$ \\
\hline Bunocotyle cingulata & Hemiuridae & Eurasia & $(17)$ \\
\hline Bunodera luciopercae & Allocreadiidae & Widespread & $(40)$ \\
\hline Diplostomum chromatophorum (m) & Diplostomidae & Eurasia & (21) \\
\hline Diplostomum commutatum (m) & Diplostomidae & Eurasia & $(3 *)$ \\
\hline Diplostomum helveticum (m) & Diplostomidae & Eurasia & $\left(3^{*}\right)$ \\
\hline Diplostomum mergi $(\mathrm{m})$ & Diplostomidae & Widespread & $\left(3^{*}\right)$ \\
\hline $\begin{array}{l}\text { Diplostomum spathaceum }(\mathrm{m}) \\
\text { (Some records may be } \\
\text { Diplostomum pseudospathaceum } \\
\text { which is morphologically similar) }\end{array}$ & Diplostomidae & Widespread & $(3,17,18,20,24)$ \\
\hline Hysteromorpha triloba $(\mathrm{m})$ & Diplostomidae & Widespread & $(3,17)$ \\
\hline Ichthyocotylurus erraticus (m) & Strigeidae & Widespread & (3) \\
\hline Ichthyocotylurus pileatus (m) & Strigeidae & Widespread & $(3,17,21,24)$ \\
\hline Ichthyocotylurus platycephalus (m) & Strigeidae & Widespread & $(3,17,20,21,33,35)$ \\
\hline Icthyocotylurus variegatus (m) & Strigeidae & Eurasia & $(3,37)$ \\
\hline $\begin{array}{l}\text { Mesostephanus appendiculatoides } \\
(\mathrm{m})\end{array}$ & Cyathocotylidae & Widespread & $(3 *)$ \\
\hline Metorchis bilis (m) & Opisthorchiidae & Eurasia & $\left(3^{*}\right)$ \\
\hline Metorchis xanthosomus (m) & Opisthorchiidae & Eurasia & $\left(3^{*}\right)$ \\
\hline
\end{tabular}




\begin{tabular}{|c|c|c|c|}
\hline Taxonomic groups/species & Family & Geographical distribution & Reference(s) \\
\hline Metagonimus yokogawai (m) & Heterophyidae & Eurasia & $(3,17,22,24)$ \\
\hline Nicolla skrjabini & Opecoelidae & Eurasia & $(24,25)$ \\
\hline Opisthorchis felineus (m) & Opisthorchiidae & Eurasia & $(3,17,21)$ \\
\hline Palaeorchis incognitus & Lissorchiidae & Eurasia & $(3,24)$ \\
\hline Paracoenogonimus ovatus (m) & Cyathocotylidae & Eurasia & $(3 *, 14,17,20,21,24,35)$ \\
\hline Phyllodistomum folium & Gorgoderidae & Eurasia & $(3,17,21,22)$ \\
\hline Phyllodistomum macrocotyle & Gorgoderidae & Eurasia & $(17)$ \\
\hline Plagioporus angusticolle & Opecoelidae & Eurasia & $(20)$ \\
\hline Posthodiplostomum cuticola (m) & Diplostomidae & Widespread & $(3,17,20,22,24,35)$ \\
\hline Pseudamphistomum truncatum (m) & Opisthorchidae & Eurasia & $\left(3^{*}\right)$ \\
\hline Rhipidocotyle campanula (m) & Bucephalidae & Eurasia & $(3,6,21,22,24,37)$ \\
\hline Rhipidocotyle fennica (m) & Bucephalidae & Eurasia & $(37)$ \\
\hline Sanguinicola armatus & Aporocotylidae & Eurasia (one record in USA) & $(22)$ \\
\hline Sanguinicola volgensis & Aporocotylidae & Eurasia & $(3,14,17,35)$ \\
\hline Sphaerostoma bramae & Opecoelidae & Eurasia & $(3,17,18,20,27)$ \\
\hline Sphaerostoma globiporum & Opecoelidae & Eurasia & $\left(3^{*}, 21,22,24,40\right)$ \\
\hline Sphaerostoma minus & Opecoelidae & Rare specialist, Curonian Lagoon & (3) \\
\hline Tylodelphys clavata (m) & Diplostomidae & Widespread & $\left(3^{*}, 14,18,20,22,24,33,35\right)$ \\
\hline \multicolumn{4}{|l|}{ Phylum: Nematoda } \\
\hline \multicolumn{4}{|l|}{ Class: Chromadorea } \\
\hline Anguillicoloides crassus (1) & Anguillicolidae & Adult is eel specialist, widespread & $(39)$ \\
\hline Anisakis simplex (1) & Anisakidae & Widespread & $(35)$ \\
\hline Camallanus lacustris & Camallanidae & Widespread & $(3,40)$ \\
\hline Camallanus truncatus & Camallanidae & Widespread & $(40)$ \\
\hline Cucullanus dogieli & Cucullanidae & Eurasia & $(3,23)$ \\
\hline Cucullanus heterochrous & Cucullanidae & Eurasia & $(20)$ \\
\hline Desmidocercella numidica (1) & Desmidocercidae & Widespread & $\left(3^{*}\right)$ \\
\hline Gnathostoma hispidum (1) & Gnathostomatidae & Eurasia & $\left(3^{*}\right)$ \\
\hline
\end{tabular}




\begin{tabular}{|c|c|c|c|}
\hline Taxonomic groups/species & Family & Geographical distribution & Reference(s) \\
\hline Hysterothylacium aduncum (1) & Raphidascarididae & Widespread & $(27)$ \\
\hline Molnaria intestinalis & Skrjabillanidae & Eurasia & $(23)$ \\
\hline Philometra ovata & Philometridae & Eurasia & $(3,17)$ \\
\hline Philometra rischta & Philometridae & Eurasia & $(6,17,24,35)$ \\
\hline Pseudoterranova decipiens (1) & Anisakidae & Widespread & $(27)$ \\
\hline Raphidascaris acus (1) & Raphidascarididae & Widespread & $(8,17,20,23,37,40)$ \\
\hline Rhabdochona denudata & Rhabdochonidae & Eurasia & $(3,8,17)$ \\
\hline Spiroxys contorta $(\mathrm{l})$ & Gnathostomatidae & Widespread & $(23,24)$ \\
\hline Streptocara crassicauda & Acuariidae & Widespread & $(35)$ \\
\hline \multicolumn{4}{|l|}{ Class: Enoplea } \\
\hline Dioctophyme renale (1) & Dioctophymidae & Widespread & $(23)$ \\
\hline Eustrongylides excisus (1) & Dioctophymidae & Eurasia & $(23)$ \\
\hline Pseudocapillaria tomentosa & Capillariidae & Widespread & $(20,23,40)$ \\
\hline Schulmanela petruschewskii & Capillariidae & Eurasia & $(23)$ \\
\hline \multicolumn{4}{|l|}{ Phylum: Acanthocephala } \\
\hline \multicolumn{4}{|l|}{ Class: Palaecanthocephala } \\
\hline Acanthocephalus anguillae & Echinorhynchidae & Eurasia & $(8,12,14,17,18,20,35,37,40)$ \\
\hline Acanthocephalus clavula & Echinorhynchidae & Eurasia & $(17,18)$ \\
\hline Acanthocephalus gracilacanthus & Echinorhynchidae & Eurasia & $(29,33)$ \\
\hline Acanthocephalus lucii & Echinorhynchidae & Eurasia & $(6,8,35)$ \\
\hline Corynosoma semerme (1) & Polymorphidae & Widespread & $(20)$ \\
\hline Echinorhynchus salmonis & Echinorhynchidae & Widespread & $(18)$ \\
\hline Neoechinorhynchus rutili & Neoechinorhynchidae & Widespread & $(3,6,8,17,18,35)$ \\
\hline $\begin{array}{l}\text { Pomphorhynchus laevis (Some } \\
\text { records may be Pomphorhynchus } \\
\text { tereticollis which is } \\
\text { morphologically similar) } \\
\text { Phylum: Annelida }\end{array}$ & Pomphorhynchidae & Eurasia & $(3,6,12,17,20)$ \\
\hline Class: Clitellata & & & \\
\hline
\end{tabular}




\begin{tabular}{llll}
\hline Taxonomic groups/species & Family & Geographical distribution & Reference(s) \\
\hline $\begin{array}{l}\text { Hemiclepsis marginata } \\
\text { Piscicola geometra }\end{array}$ & Glossophoniidae & Eurasia & $(3,17,35)$ \\
$\begin{array}{l}\text { Phylum: Mollusca } \\
\text { Class: Bivalvia }\end{array}$ & Piscicolidae & Widespread & $(3,17,18,24,35)$ \\
Glochidia larvae & & & \\
Phylum: Arthropoda (Crustacea) & Margaritiferidae & Widespread & $(14,17,24,35,37)$ \\
Class: Hexanauplia & & & \\
Caligus lacustris & Caligidae & Eurasia & $(5)$ \\
Ergasilus briani & Ergasilidae & Eurasia & $(3,5,17,20)$ \\
Ergasilus sieboldi & Ergasilidae & Eurasia & $(5,14,17,20,24,33,35,37)$ \\
Lamproglena pulchella & Lernaeidae & Eurasia & $(3,5,17,20,24)$ \\
Lernaea cyprinacea & Lernaeidae & Widespread & $(5)$ \\
Tracheliastes polycolpus & Lernaeopodidae & Palaearctic & $(5,14,17,18,20,24,35,37)$ \\
Class: Ichthyostraca & & & $(5,24)$ \\
Argulus coregoni & Argulidae & Widespread & $(3,5,17,24,35,37)$ \\
Argulus foliaceus & Argulidae & Eurasia & \\
\hline
\end{tabular}

${ }^{1}$ Bauer (1984); ${ }^{2}$ Bauer (1985); ${ }^{3}$ Bauer (1987); ${ }^{4}$ Cech et al. (2012); ${ }^{5}$ de Charleroy et al. (1993); ${ }^{6}$ Djikanovic et al. (2012); ${ }^{7}$ Dorovskikh (1997); ${ }^{8}$ Dorovskikh (1999);

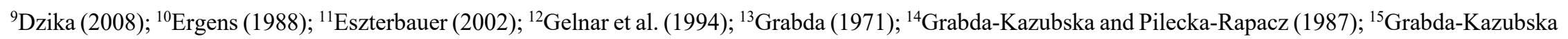
and Okulewicz (2005); ${ }^{16} \mathrm{Hao}$ et al. (2014); ${ }^{17}$ Izyumova (1987); ${ }^{18} \mathrm{Järvalt} \mathrm{et} \mathrm{al.} \mathrm{(2003);}{ }^{19} \mathrm{Jezzewski}$ and Kamara (1999); ${ }^{20} \mathrm{Kirjušina} \mathrm{and} \mathrm{Vismanis} \mathrm{(2007);}{ }^{21} \mathrm{Liberman}$ (2020); ${ }^{22}$ Molnar (1969); ${ }^{23}$ Moravec (1994); ${ }^{24}$ Moravec (2001); ${ }^{25}$ Niewiadomska (2003); ${ }^{26}$ Ondračkova et al. (2004); ${ }^{27}$ Palm et al. (1999); ${ }^{28}$ Pojmańska (1991); ${ }^{29}$ Popiołek (2016); ${ }^{30}$ Pugachev et al. (2009); ${ }^{31}$ Rautskis (1988); ${ }^{32}$ Rokicki (2004); ${ }^{33}$ Rolbiecki (2003); ${ }^{34}$ Rusinek (2007); ${ }^{35}$ Sobecka et al. (2004); ${ }^{36}$ Sterud (1999); ${ }^{37}$ Sterud and Appleby (1997); ${ }^{38}$ Sterud and Poynton (2002); ${ }^{39}$ Thomas and Ollevier (1992); ${ }^{40}$ Zhokhov (2003). 